\title{
KEPALA NEGARA NON MUSLIM MENURUT IBNU TAIMIYYAH (661-728H)
}

\section{TESIS}

Diajukan Untuk Melengkapi Salah Satu Syarat Guna Memperoleh Gelar Magister Hukum (M.H.) Pada Program Studi Hukum Keluarga

(Ahwal al-Syakhshiyah)

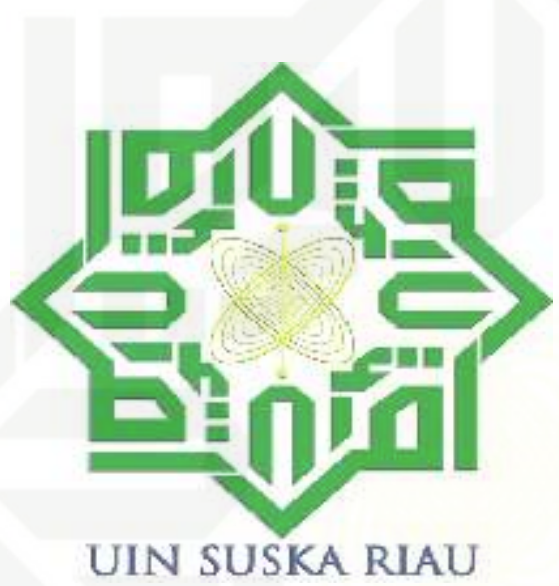

OLEH:

ISNEN AZHAR

NIM. 21692104663

\author{
PROGRAM PASCASARJANA (PPs) \\ UNIVERSITAS ISLAM NEGERI (UIN) \\ SULTAN SYARIF KASIM RIAU \\ 1441 H. / 2019 M.
}




\section{KEMENTERIAN AGAMA RI \\ UNIVERSITAS ISLAM NEGERI SULTAN SYARIF KASIM RIAU \\ PROGRAM PASCASARJANA \\ كابنة الدابان}

THE GRADUATE PROGRAMME

UUIP SESKA RIAU

Alamat: JI. K.H. Ahmad Dahlan No. 94 Pekanbaru 28129 PO.BOX. 1004

Phone \& Facs, (0761) 858832, Site : pps.uin-suska.ac.id E-mail : pps@uin-suska.ac.id

\section{Lembaran Pengesahan}

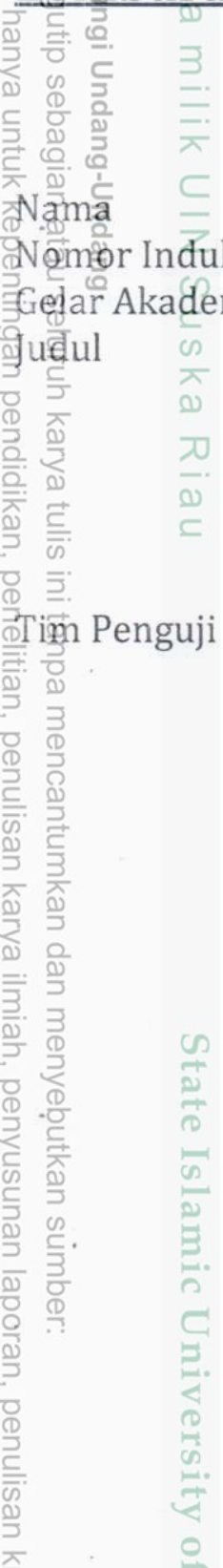

Isnen Azhar

21692104663

M.H. (Magister Hukum Keluarga)

Kepala Negara Non Muslim Menurut Ibnu Taimiyah (661$728 \mathrm{H})$.

\section{Dr. Hj. Andi Murniati, M.Pd}

Ketua

Dr. Tuti Andriani, S.Ag, M.Pd.

Sekretaris

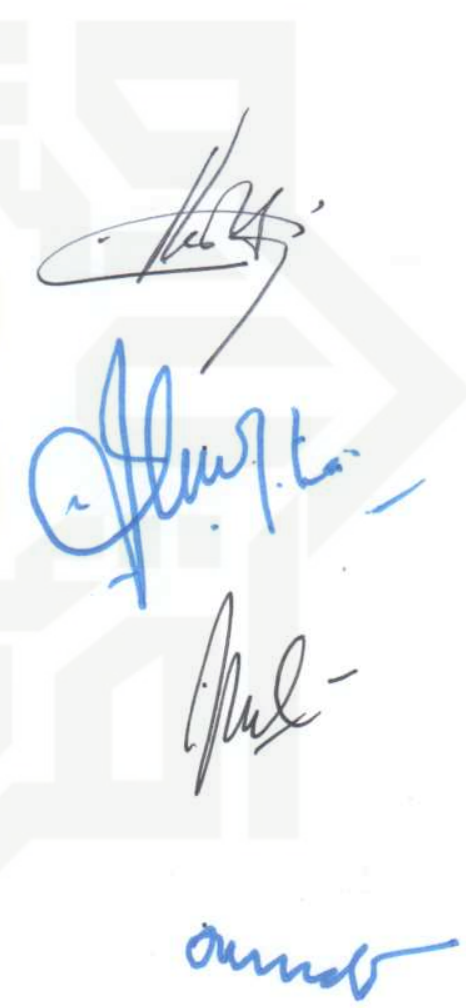

Dr. Junaidi Lubis, M.Ag

Penguji I

Dr. H. Helmi Basri, Lc., MA

Penguji II 


\section{PENGESAHAN PENGUJI TESIS}

No Kàmi yang bertanda tangan dibawah ini, selaku Penguji Tesis, mengesahkan dan $\checkmark \checkmark \overline{\bar{a}}$

menyetugui bahwa tesis yang berjudul "Kepala Negara Non Muslim Menurut Ibnu

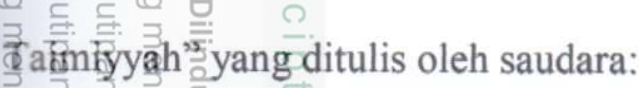

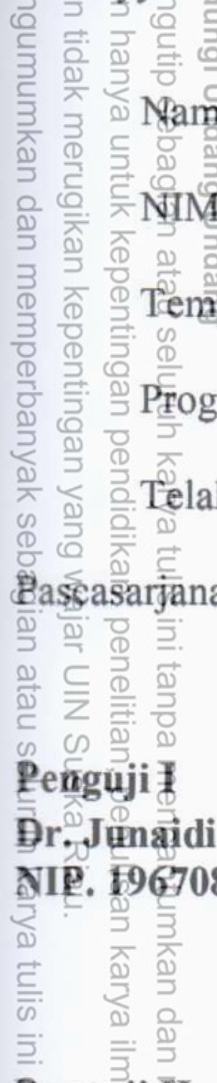

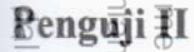

Đr. H. Helmi Basri, Lc. MA.

\$̄IP. \$97407042006041003

\section{: Isnen Azhar}

: 21692104663

: Kuntu, 2 Desember 1972

: Hukum Keluarga (Ahwâl Syakhsyiyyah)

Studi

diperbaiki dengan saran Tim Penguji Tesis pada Program diujikan dan UIN Sultan Syarif Kasim Riau, pada tanggal 24 Juni 2019

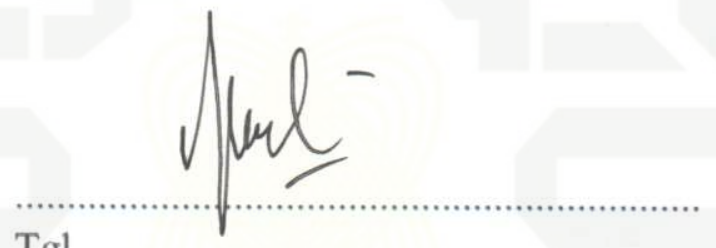

Tgl.

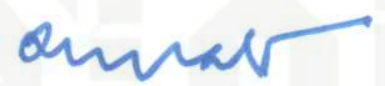

Tgl.

Mengetahui,

Ketua Program Studi Hukum Keluarga (Ahwâl Syakhsyiyyah)

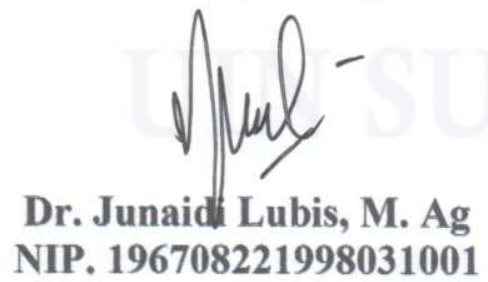

NIP. 196708221998031001 


\section{PENGESAHAN PEMBIMBING}

$\rightarrow \mathrm{K}$

Kămi yang bertanda tangan dibawah ini, selaku Pembimbing Tesis, mengesahkan dan चv

menyetujui bahwa tesis yang berjudul "Kepala Negara Non Muslim Menurut Ibnu

Daimizyän" yang ditulis oleh saudara:

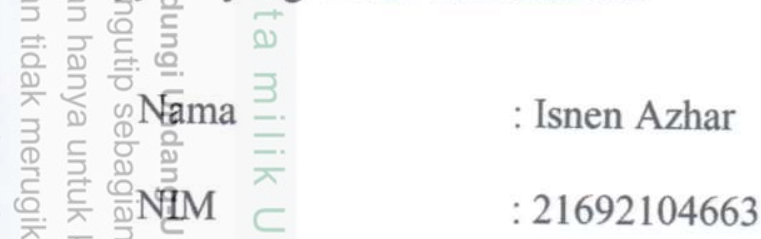

TEुmpat/Tgl Lahir : Kuntu, 2 Desember 1972

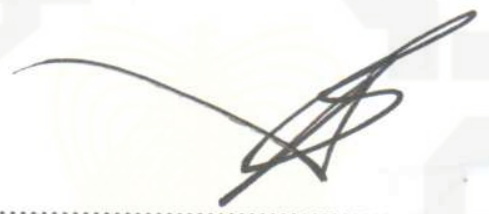

Tgl. 30 Agustus 2019

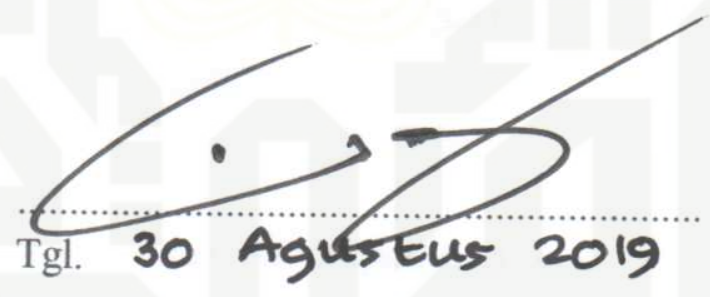

Mengetahui,

Ketua Program Studi Program Studi Hukum Keluarga (Ahwâl Syakhsyiyyah)

Dr. Junaidi Lubis, M. Ag

NIP. 196708221998031001 


\section{PESETUJUAN}

Kami yang bertanda tangan dibawah ini, selaku pembimbing tesis, dengan ini menyetuju bahwa tesis yang berjudul "Kepala Negara Non Muslim Menurut Ibnu Täingiy

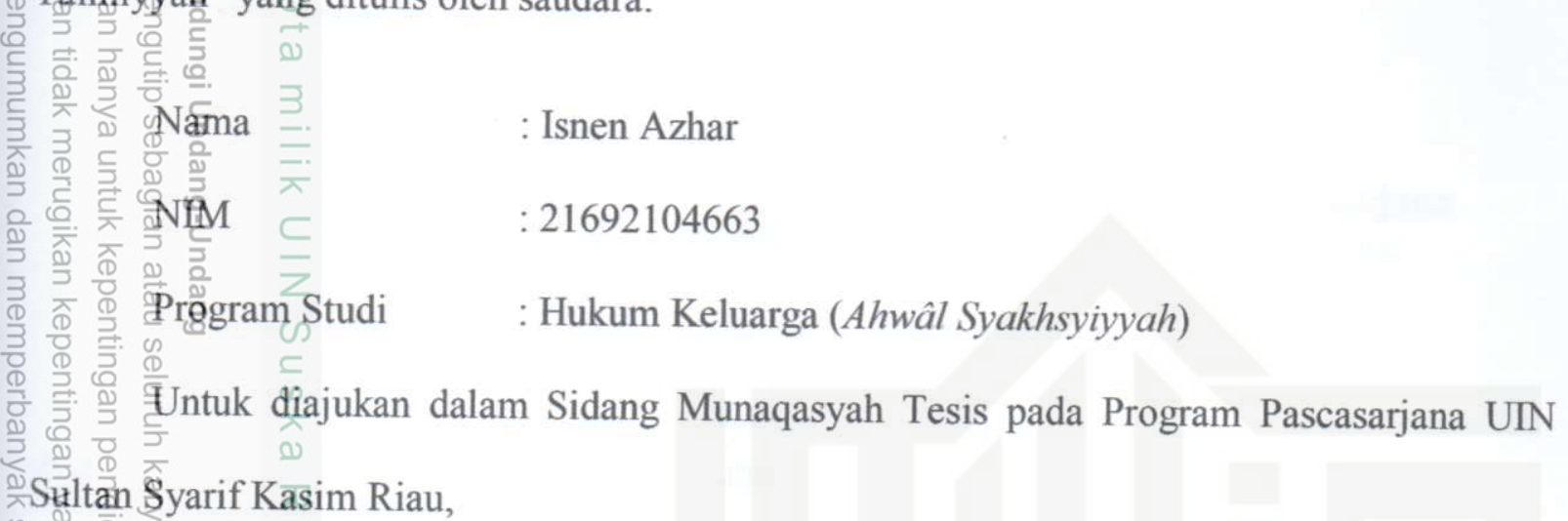
क

Pêkanbaru,

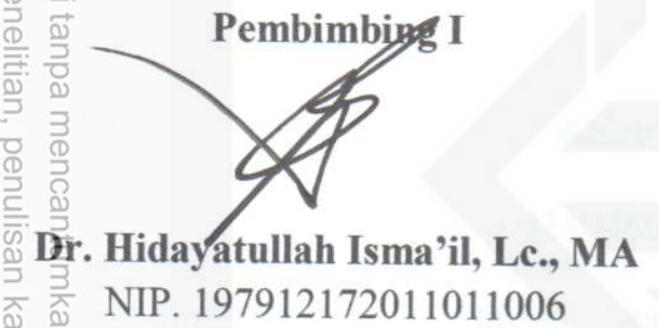

Pekanbaru,

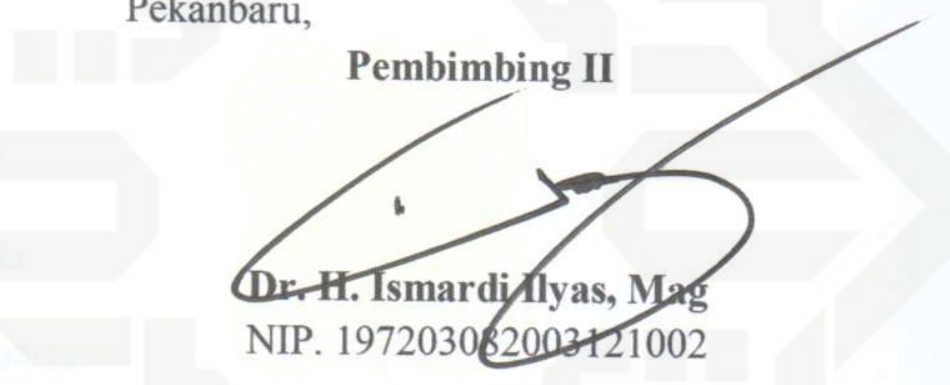

Mengetahui,

Ketua Program Studi Program Studi|Hukum Keluarga (Ahwâl Syakhsyiyyah)

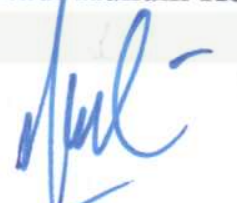

Dr. JunaidK Lubis, M. Ag

NIP. 19670822199803100 
Dr. Hidayatullah Isma'il, Lc., MA

DOSEN PROGRAM PASCASARJANA

UNIVERSITAS ISLAM NEGERI

SULTAN STY STIF KASIM RIAU

\section{MOT DINAS}

其些: Tesis Saudara

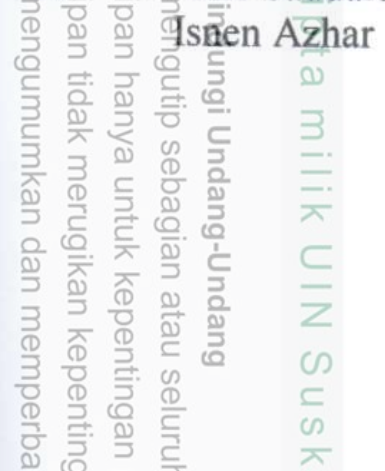

Kepada Yth,

Direktur Program Pascasarjana

UIN Sultan Syarif Kasim Riau, di -

Pekanbaru

Assẩlầmự ‘alaikum Warahmatullâhi Wabarakâtuh

is ฏे)

O

Fesis sautara:

: Isnen Azhar

: 21692104663

: Hukum Keluarga (Ahwâl Syakhsyiyyah)

: Kepala Negara Non Muslim Menurut Ibnu Taimiyyah

gan ini dapat disetujui untuk diuji dan diberikan penilaian dalam sidang

Pascasarjana UIN Suska Riau,

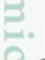

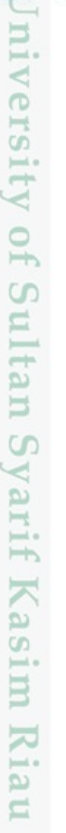

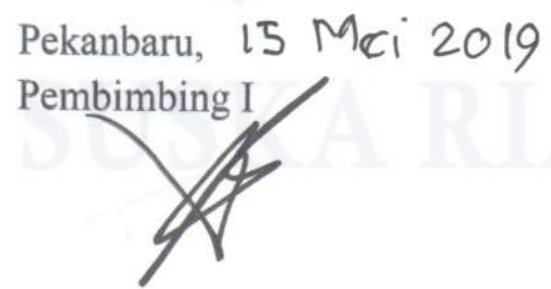

Dr. Hidayatullah Isma'il, Lc., MA

NIP. 197912172011011006 
Kepada Yth, Direktur Program Pascasarjana UIN Sultan Syarif Kasim Riau, di -

\section{Pekanbaru}

Setelah kami membaca, meneliti, mengoreksi dan mengadakan perbaikan terhadap isi (2)

Fesis'saundara:

: Isnen Azhar

Vama

NैIM

: 21692104663

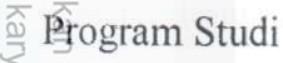

aิ

Jüdul

$\frac{2}{d}$

Maka dengan ini dapat disetujui untuk diuji dan diberikan penilaian dalam sidang

$\stackrel{\infty}{\geq}$

赛sis pada Program Pascasarjana UIN Suska Riau,

: Hukum Keluarga (Ahwâl Syakhsyiyyah)

: Kepala Negara Non Muslim Menurut Ibnu Taimiyyah

Assalầmı 'alaikum Warahmatullâhi Wabarakâtuh

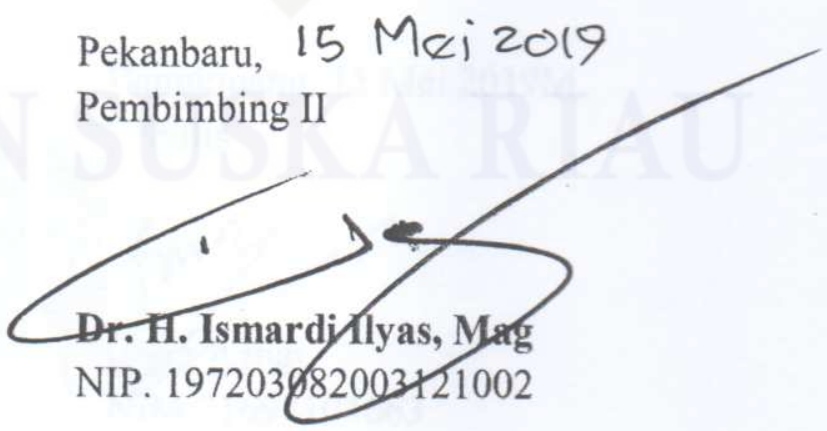




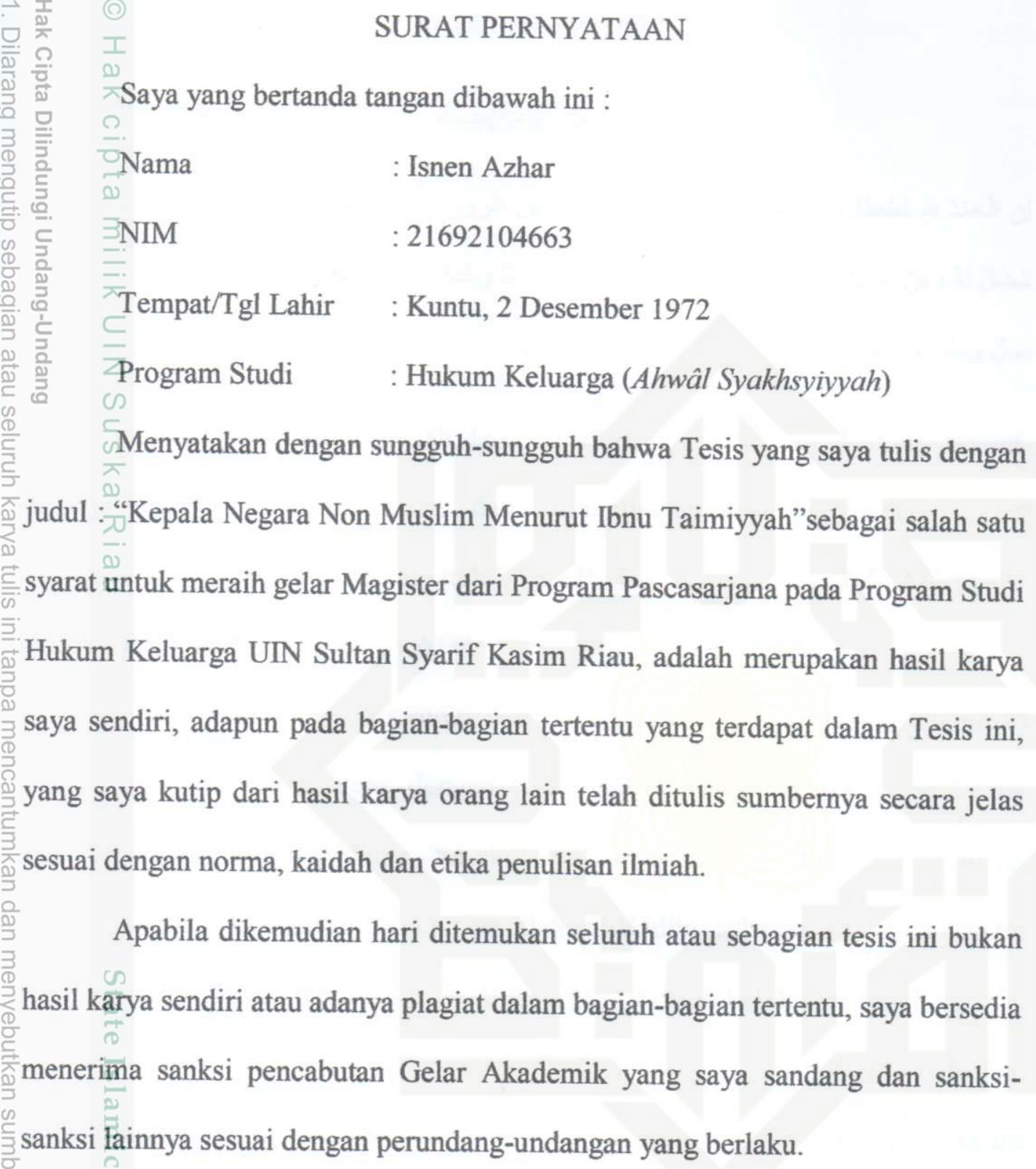

Apabila dikemudian hari ditemukan seluruh atau sebagian tesis ini bukan hasil karya sendiri atau adanya plagiat dalam bagian-bagian tertentu, saya bersedia menerima sanksi pencabutan Gelar Akademik yang saya sandang dan sanksiב sanksi lainnya sesuai dengan perundang-undangan yang berlaku.

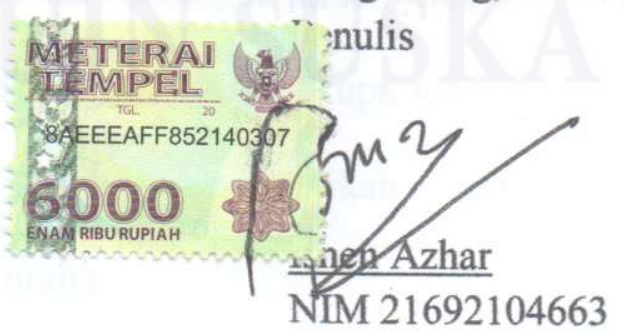




\section{KATA PENGANTAR}

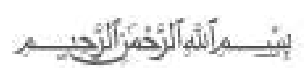

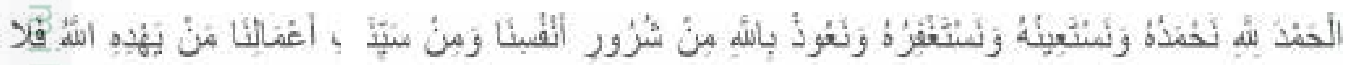

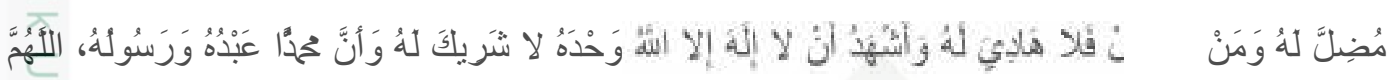

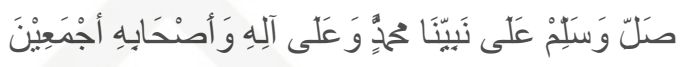

Segala puji kehadirat Allah Azza wa Jalla, yang telah memberikan rahmat, taufiq hidayah serta kesehatan dan kemampuan, sehingga penulis dapat menyelesaikan tesis ini dengan judul "KEPALA NEGARA NON MUSLIM MENURUT IBNU TAIMIYYAH"

Shalawat serta salam semoga selalu tercurahkan kepada Nabi Muhammad shallallahu 'alaihi wasallam, dengan sebab beliau ummat manusia bisa keluar dari kebodohan terhadap dunia dan akhirat sehingga manusia bisa paham tujuan hidup dengan menjadikan al-Qur'an dan al-Hadits sebagai petunjuk dalam menjalani kehidupan di dunia ini menuju surga di akhirat kelak.

Tesis ini merupakan persyaratan untuk memperoleh gelar Magister Hukum pada Program Studi Hukum Keluarga, Program Pascasarjana (PPs) Universitas Isläm Negeri Sultan Syarif Kasim Riau. Di dalam menyusun karya tulis ilmiah ini tentu tidak terlepas dari peran dari berbagai pihak yang telah mendorong dan memberikan bimbingan kepada penulis, baik berupa tenaga maupun pemikiran, (5)

oleh karena itu perkenankan penulis menyampaikan ucapan terima kasih yang sebesar-besarnya kepada yang mulia : 
1. Ibundaku Syarifah (rahimahallah) dan Ayahandaku Abdur Rahman (rahimahullah) yang dengan sebab keduanya, penulis terlahir dan berada di dunia ini, serta ucapan terima kasihku kepada saudara-saudariku: Gafar Jamal, Ahmad Ridwan, Jirul Amin, Saridan, dan juga ucapan terima kasihku yang sangat terkhusus kepada Istri saya tercinta Lina Marlini yang telah mendampingi penulis dan telah berkorban dalam banyak hal semenjak pernikahan kami akhir Juli 1997 sampai saat ini, serta anakanakku tersayang Abdullah Zahabi, Sumayyah Azzahro dan Rifdah Syamilah.

2. Bapak Prof. Dr. H. Akhmad Mujahidin, S.Ag, M.Ag selaku Rektor Universitas Islam Negeri Sultan Syarif Kasim Riau.

3. Bapak Prof. Dr. H. Afrizal M, MA selaku Direktur Program Pascasarjana (PPs) Universitas Islam Negeri Sultan Syarif Kasim Riau.

4. Bapak Drs. H. Iskandar Arnel MA., Ph.D selaku Wakil Direktur Program Pascasarjana (PPs) Universitas Islam Negeri Sultan Syarif Kasim Riau.

5. Bapak Dr. Junaidi Lubis M.Ag selaku ketua Prodi Hukum Keluarga Program Pascasarjana (PPs) Universitas Islam Negeri Sultan Syarif Kasim Riau.

6. Bapak Dr. H. Hidayatullah Ismail, Lc, MA, selaku Pembimbing Utama (I) dan Dr. H. Ismardi Ilyas, M.Ag, selaku Pembimbing Pendamping (II) dalam penyusunan tesis ini.

7. Bapak dan Ibu Dosen yang telah mentransper ilmu pengetahuan dan pengelaman serta bimbingan kepada kami selama kami mengikuti materi- 
materi perkuliahan pada Program Prodi Hukum Keluarga Program Pascasarjana (PPs) Universitas Islam Negeri Sultan Syarif Kasim Riau.

8. Seluruh staff, karyawan dan karyawati yang ada dalam lingkungan kerja pada Program Pascasarjana (PPs) Universitas Islam Negeri Sultan Syarif Kasim Riau.

9. Seluruh Civitas Akademika di lingkungan Program Pascasarjana (PPs) Universitas Islam Negeri Sultan Syarif Kasim Riau.

10. Guru-guru dan teman-teman seperjuangan baik guru maupun karyawan yang ada di lingkungan Pondok Pesantren Syekh Muhammad Bin Sholeh al-Utsaimin Bangkinang Riau yang ada dibawah Yayasan Lajnah alKhairiyyah al-Musytarakah cabang Bangkinang dan Yayasan Lajnah alKhairiyyah al-Musytarakah Pusat Jakarta

11. Donator yang telah menyumbangankan hartanya dalam program beasiswa melalui Yayasan Lajnah al-Khairiyyah al-Musytarakah Jakarta

12. Guru-guru dan teman-teman seperjuangan seangkatan abituren pada tahun 1993M Pondok Pesantren Daarun Nahdhah Thawalib Bangkinang.

13. Sahabat-sahabat penulis yang seangkatan pada Program Prodi Hukum Keluarga Program Pascasarjana (PPs) Universitas Islam Negeri Sultan Syarif Kasim Riau, (Riadul Afkar, M. Nafis, Ibrahim, Oki Pendri, Indra Jaya, Novri Naldi Sapni, M. Sholeh Hasibuan, Amirul Mukminin, Abdul Kemal Batunara, Hasmiati) mereka adalah penyemangat dan pendorong penulis untuk menyelesaikan tesis ini. 
Semoga Allah Azza wa Jalla memberikan balasan yang berlipat ganda dan ganjaran surga kepada mereka atas kebaikkan mereka kepada penulis, dan penulis menyadari bahwa tesis ini masih jauh dari sebutan sempurna, untuk itu penulis $\exists$ berharap kritikan dan saran yang membangun, semoga tesis ini dapat memberikan ilmu dan kontribusi bermanfaat dalam khazanah keislaman bagi kaum muslimin dan bangsa Indonesia.

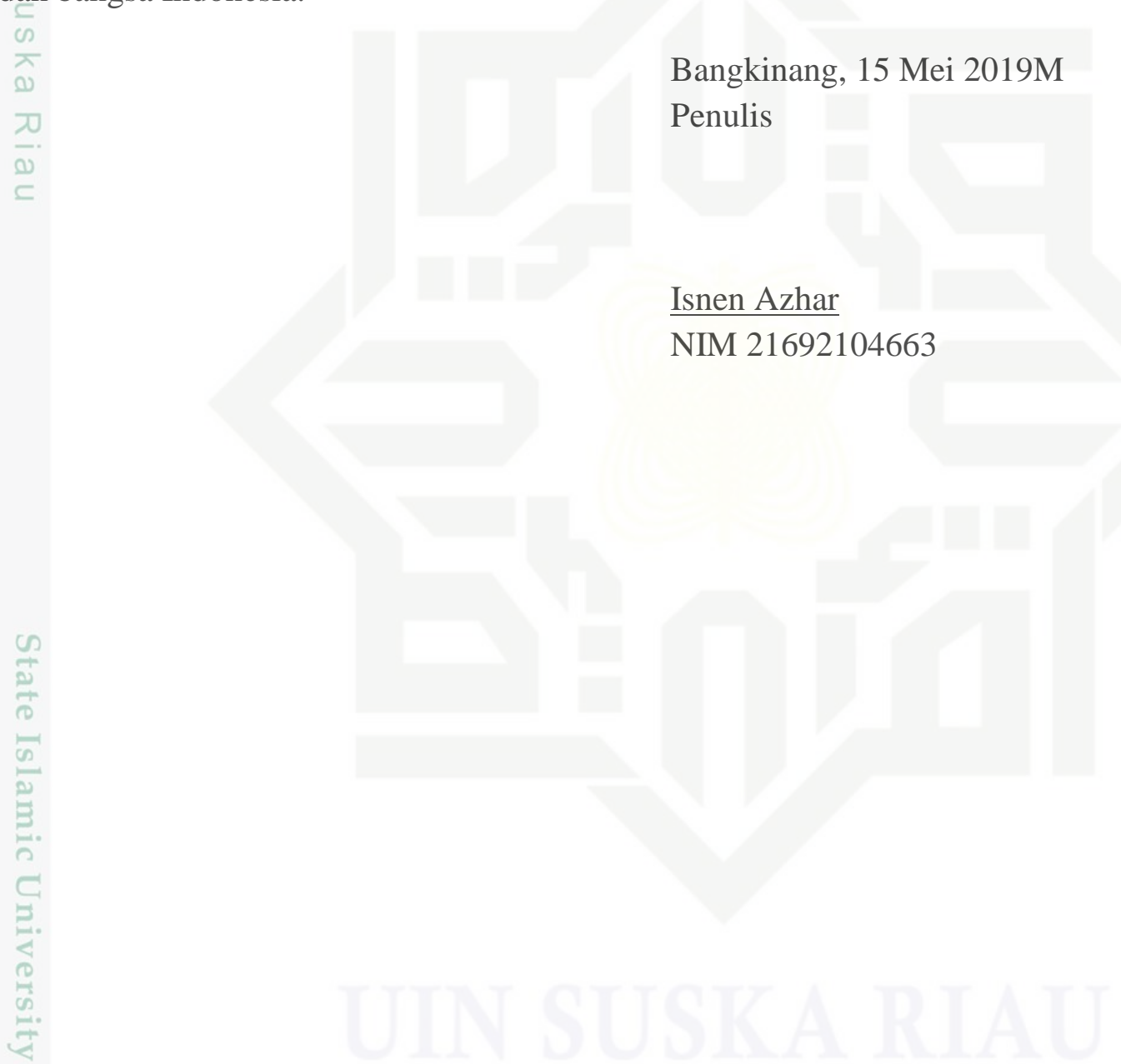




\section{DAFTAR ISI}

HALAMAN JUDUL

NOTA DINAS

PERSETUJUAN PEMBIMBING DAN KETUA PRODI

SURAT PERNYATAAN

KATA PENGANTAR

DAFTAR ISI

$\mathbf{v}$

PEDOMAN TRANSLITERASI $\quad$........................................................................... vii

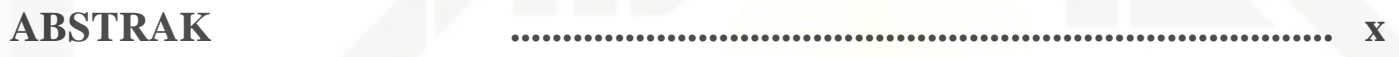

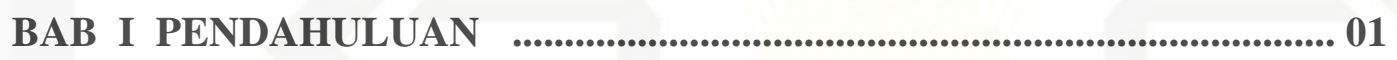

A. Latar Belakang Masalah ................................................................ 01

B. Fokus Penelitian ................................................................................ 14

1. Identifikasi Masalah ...................................................................... 14

2. Batasan Masalah $\quad$.................................................................. 14

3. Rumusan Masalah $\quad$............................................................... 15

4. Tujuan dan Kegunaan Penelitian $\quad$........................................... 15

a. Tujuan Penelitian ...................................................................... 15

b. Manfaat Penelitian ...................................................................... 16

5. Sistematika Penulisan ..................................................................... 16

BAB II LANDASAN TEORI $\quad$............................................................. 19

A. Kepemimpinan $\quad$............................................................... 19

1) Pengertian Kepemimpinan $\quad$........................................................ 19

2) Urgensi Seorang Pemimpin Dalam Islam ................................. 25

3) Dasar Hukum Kepemimpinan Dalam Islam ................................ 29

4) Syarat-syarat Seorang Pemimpin Dalam Islam $\quad$.................... 33 
5) Tugas Dan Kewajiban Seorang Pemimpin Dalam Islam ...... 38

6) Macam-Macam Kepemimpinan Dalam Islam $\quad$................... 41

7) Kepemimpinan Non Muslim Dalam Literatur Islam ................... 42

1. Kepemimpinan Non Muslim Berdasarkan al-Qur'an ....... 42

2. Kepemimpinan Non Muslim Berdasarkan al-Sunnah ....... 49

3. Kepemimpinan Non Muslim Berdasarkan Ijma' Ulama ....... 55

B. Biografi Ibnu Taimiyyah $\quad$................................................................ 58

C. Penelitian Yang Relevan Dengan Judul Tesis .............................. 84

BAB III METODOLOGI PENELITIAN .................................................... 93

A. Jenis Dan Pendekatan Penelitian ........................................................ 93

B. Sifat Penelitian $\quad$.................................................................................... 93

C. Bahan Penggalian Data $\quad$............................................................................ 94

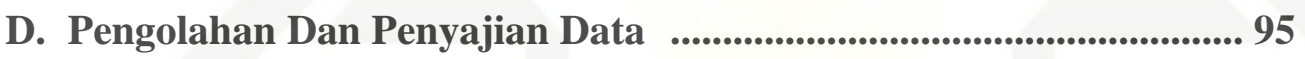

E. Analisis Data $\quad$............................................................................... 96

BAB IV HASIL TEMUAN PENELITIAN ................................................. 97

A. Kepala Negara Dan Negara Menurut Ibnu Taimiyyah ................... 97

1. Konsep Negara Menurut Ibnu Taimiyyah ............................... 97

2. Konsep Kepala Negara Menurut Ibnu Taimiyyah..................... 101

B. Syarat-Syarat Kepemimpinan Menurut Ibnu Taimiyya.............. 104

C. Kepemimpinan Non Muslim Menurut Ibnu Taimiyyah................. 116

D. Relevansi Pandangan Ibnu Taimiyyah Dengan Kekinian .............. 139

BAB V PENUTUP $\quad$............................................................................ 142

A. Kesimpulan ............................................................................................. 142

B. Saran $\quad$........................................................................................... 144

\section{DAFTAR PUSTAKA}




\section{ABSTRAK}

\section{Isnen Azhar: 2019 "Kepala Negara Non Muslim Menurut Ibnu Taimiyyah"}

Masalah kepemimpinan bukan hanya persoalan duniawi, akan tetapi juga persoalan ukhrawi yang mana manusia itu akan dimintai pertanggung-jawabannya dihadapan Allah Subhânahu Wa-Ta'âlâ pada hari kiamat kelak, oleh karena itu urgensi seorang pemimpin dalam kehidupan bermasyarakat, berbangsa dan bernegara telah dijelaskan oleh Allah dan RasulNya, bahkan dalam sebuah komunitas kecil masyarakat seperti dalam sebuah perjalanan, maka Nabi kita Muhammad shallallahu 'alaihi wasallam telah mengintruksikan agar diangkat séorang pemimpin.

Jenis penelitian adalah bersifat kepustakaan (library research). Pendekatan yang digunakan dalam penelitian ini adalah normatif. Penelitian ini bersifat deskriftif, analitif, kualitatif. Pengumpulan data dalam penelitian ini dilakukan melalui studi kepustakaan atau observasi literatur yang ada hubungannya dengan pokok permasalahan yang dibahas.

Sumber data primer dalam penelitian ini adalah al-Siyâsah al-Syar'iyyah $f i$ Islâhi al-Râ'î wa al-Ra'iyyah karya Ibnu Taimiyyah, Al-Hisbah karya Ibnu Taimiyyah, Iqtidhô Shirôthô al-Mustaqîm Li-Mukhôlafati Ashâbi al-Jahîm karya Ibnu Taimiyyah, Sedangkan data sekundarnya adalah referensi yang memiliki kolerasi dan relevansi dengan judul penelitian

Sebagai hasil penelitaian dalam masalah urgensi kepemimpinan dalam masyarakat Islam, maka penulis menjelaskan pandangan Ibnu Taimiyyah rahimahullah telah membuat persyaratan yang ketat bagi seorang calon pemimpin dengan karakter sebagai berikut: (1). al-Muslim (2). al-Qowiy (3). al-Amin (4). al-Adl (5). al-Khasyyah, Ibnu Taimiyyah rahimahullah telah menjadikan syarat yang paling mendasar pada diri seorang calon pemimpin itu adalah dia wajib seorang "muslim yang hanif",

Ibnu Taimiyyah rahimahullah tidak pernah memberikan peluang dan ruang sedikitpun kepada Non Muslim untuk bisa menjadi pemimpin di tengah mayoritas Islam, diantara bentuk penolakannya terhadap kepemimpinan Non Muslim di tengah mayoritas Islam adalah tulisan beliau yang sangat terang dan jelas tentang hal itu diantaranya : (النهي عن موالاة الكفار) "larangan menjadikan orang-orang kafir sebagai pemimpin" dan beliau rahimahullah mengungkapkan

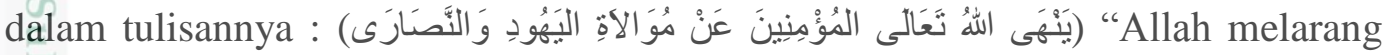
rang-orang beriman untuk menjadikan orang-orang Yahudi dan Nasrani sebagai pèmimpin". Tentang permasalahan ini penulis telah menukilkan penolakkanpenolakkan beliau rahimahullah terhadap kepemimpinan Non Muslim di tengah mayoritas Islam dalam 17 poin pada bagian terakhir dalam bab IV. 
إنّ مشكلة القبادة ليست مشكلة دنيويّة فحسب، بل هي أيضًا من مشكلة أخرويّة، حيث يُخضئح ويحاسب فيها البشر أمام الله سبحانه وتعالى يوم القيامة، وبالثّالي فقد أوضح الله ورسوله أهمّيّة القيادة في ئي

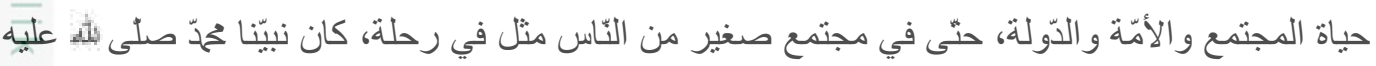

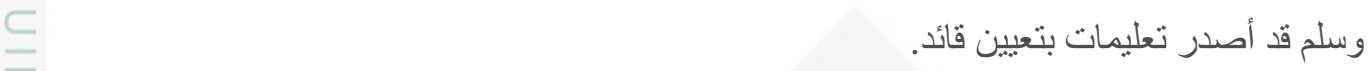

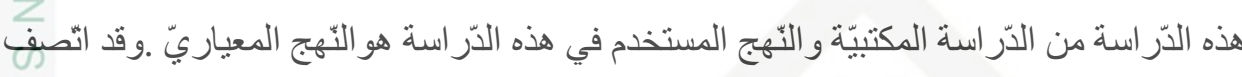

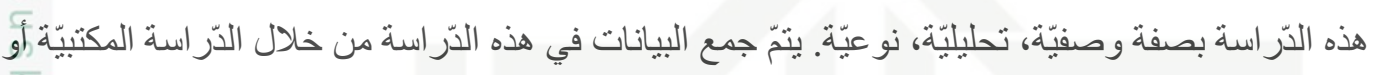
(1) ملاحظة الأدب التي لها علاقة بالموضوع.

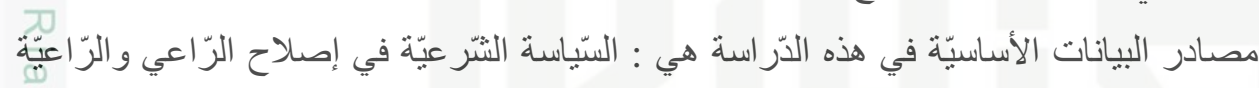

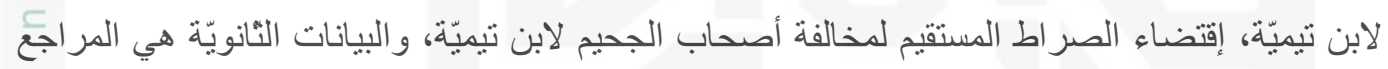
التي لها علاقة وصلة وثثقة بالبحث. لابث. نتيجة لهذه الدّر اسة في مسألة أهمّيّة القيادة في المجتمعات الإسلامية، شرح الباحث وجهة نظر ابن

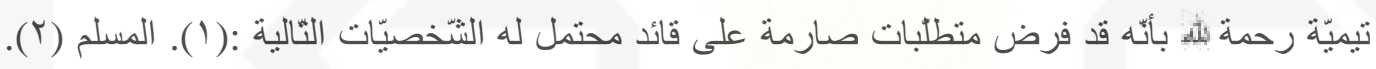
القويّ (r). الأمين (ع). العدل (0). الخشية، وقد جعل ابن تيميّة رحمه الله المطلب الأساسيّ لزعيم محتمل

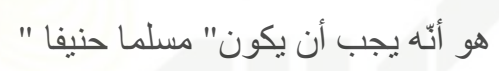
ولم يمنح ابن تيميّة رحمه الله الفرصة والفضاء لغير المسلمين ليصبحوا قائدين في وسط أغليّة المسلمين، وبين أثكال رفضه للقبادة غير المسلم في خضم غاليّيّة الإسلام كتاباته الو اضحة بما في ذللك :

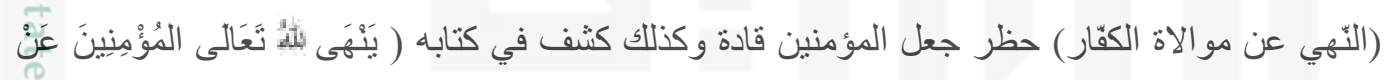

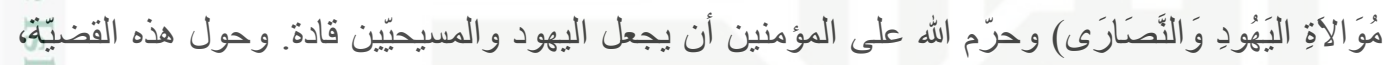

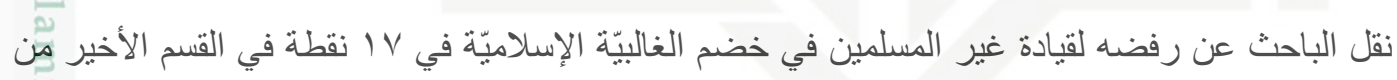
الفصل الرّابع. 


\section{ABSTRACT}

\section{Isnen Azhar (2019) : Non-Muslim Leader of A State Based on Ibnu Taimiyyah}

The problem of leadership is not only a worldly problem but also a matter of ukhrawi in which human beings will be held accountable before Allah the Almighty on the Day of Judgment. Therefore, the urgency of a leader in the life of society, nation and state has been explained by Allah and His Messenger, even in a small community of people such as on a journey, our Prophet Muhammad Peace be Upon Him had instructed to be appointed a leader.

This type of research is library research. The approach used in this study is normative. This research is descriptive, analytical, and qualitative. Data collection in this study is carried out through library research or literature observation that has to do with the subject matter being discussed.

The primary data sources in this study are al-Siyâsah al-syar'iyyah $f i$ Islâhi al-râ'î wa al-ra'iyyah by Ibn Taimiyyah, Al-Hisbah by Ibn Taimiyyah, Iqtidhô shirôthô al-mustaqîm li-mukhôlafati ashâbi al-jahîm by Ibn Taimiyyah, Majmû al-Fatâwâ by Ibn Taymiyah. While, the current data is a reference that has correlation and relevance to the research title.

As a result of research on the issue of leadership urgency in Islamic societies, the authors explain Ibn Taimiyyah's view that Rahimahullah has made strict requirements for a prospective leader with the following characters: (1). alMuslim (2). al-Qowiy (3). al-Amin (4). al-Adl (5). al-Khasyyah. Ibn Taimiyyah rahimahullah has made the most basic requirement for a prospective leader is that he is obliged to be a "Hanif Muslim".

Ibn Taimiyyah Rahimahullah never gave Non-Muslims the opportunity and space to be able to become a leader in the midst of the Muslim majority, among the forms of his rejection of the Non-Muslim leadership in the midst of the Muslim majority was his very bright and clear writing about it: "the prohibition of making infidels as leaders" and he rahimahullah stated it in his writing: "Allah forbade Islam believers to make Jews and Christians as leaders". On this issue, the author has quoted his refusal on taking the leadership of Non-Muslims in the midst of the Islamic majority in 17 points in the last section in chapter IV. 


\section{BAB I}

\section{PENDAHULUAN}

\section{A. Latar Belakang Masalah}

Dalam agama Islam, semua persoalan yang menyangkut kehidupan ummat manusia telah diatur sedemikian rupa sehingga sangat jelas dan terang benderang serta detail. Bahkan syariat Islam itu telah mengatur urusan-urusan yang sangat o privasi dan individual. Maka sangat tidak logis dan tidak masuk akal, jika syari'at Islam itu tidak menjelaskan persoalan-persoalan yang jauh lebih agung, lebih utama, lebih besar dan lebih luas dampaknya, yaitu permasalahan mengatur hajat hidup orang banyak seperti masalah negara dan kepemimpinan dalam suatu negara. Dalam masalah negara dan kepemimpinan ini maka syari'at Islam betulbetul telah mengatur dengan sangat detail, karena permasalahan negara dan kepemimpinan sangatlah berpengaruh besar terhadap tatanan kehidupan secara umum untuk kemaslahatan ummat manusia.

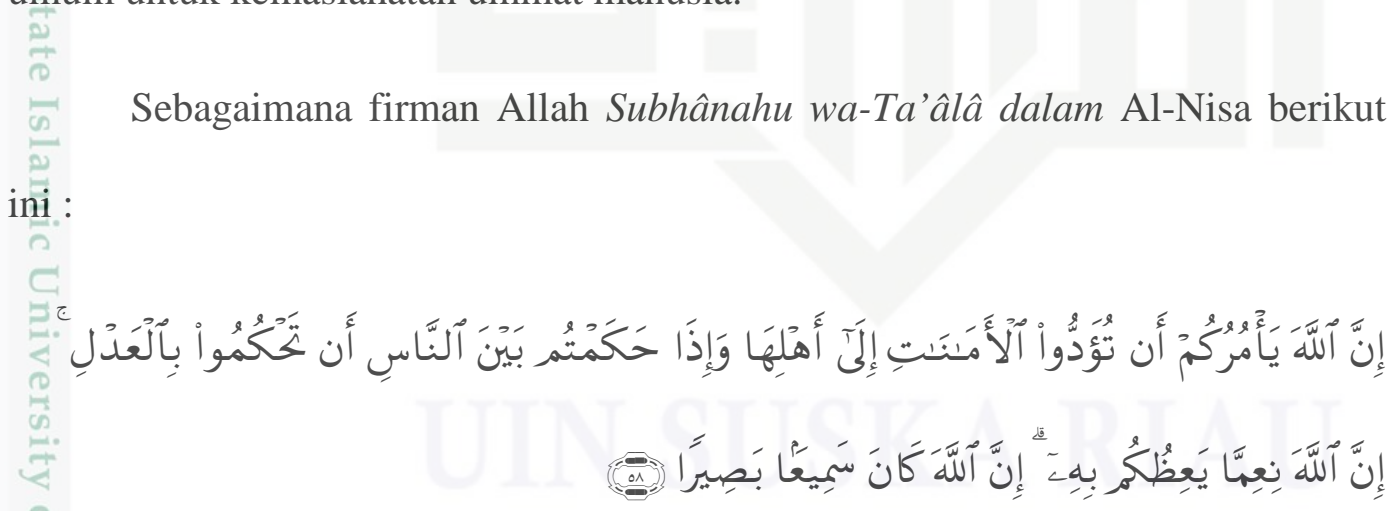

ज'Sesungguhnya Allah menyuruh kamu menyampaikan amanat kepada yang berhak menerimanya, dan (menyuruh kamu) apabila menetapkan hukum di antara manusia supaya kamu menetapkan dengan adil. Sesungguhnya Allah 
memberi pengajaran yang sebaik-baiknya kepadamu. Sesungguhnya Allah ‘ adalah Maha mendengar lagi Maha Melihat”. (QS. Al-Nisa/4 ayat 58) ${ }^{1}$ a)

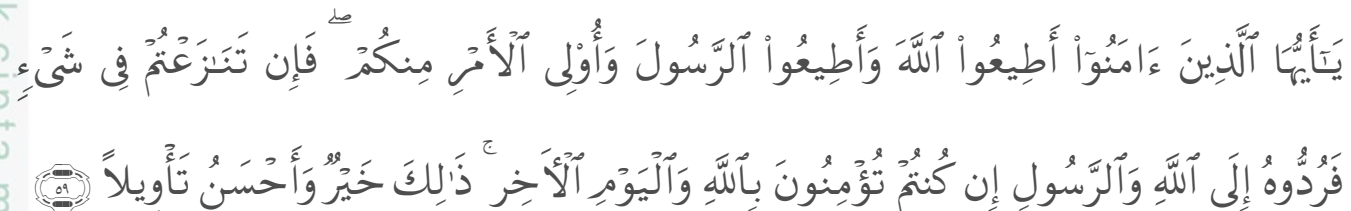

"Hai orang-orang yang beriman, taatilah Allah dan taatilah Rasul-Nya, dan Ulil Amri di antara kamu. Kemudian jika kamu berbeda pendapat tentang

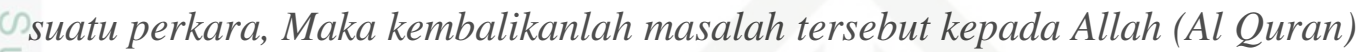
dan Rasul (Sunnahnya), jika kamu benar-benar beriman kepada Allah dan hari kemudian. yang demikian itu lebih utama (bagimu) dan lebih baik akibatnya" (QS. Al-Nisa/4 ayat 59) ${ }^{2}$

Terkait ayat ini Ali bin Abu Thalhah ia berkata : dari Ibnu Abbas radhiyallahu 'anhu ia berkata : "ulil amri" adalah ahli fiqh dan ahli agama, Mujahid, Atho', Hasan Bashri dan Abu 'Aliyah mereka berkata : "ulil amri" adalah ulama dan secara zahir wallahu 'alam ayat ini ditujukan kepada semua "ulil amri" yaitu umara' dan ulama' ${ }^{3}$

Ibnu Katsir seorang pakar tafsir bermazhab syafi'i menyimpulkan dari dua ayat diatas adalah sebagai berikut, pada ayat 58 adalah berisi perintah Allah kepada kepada siapa saja (termasuk pemimpin) agar mereka menunaikan amanah yang ada pada pundak mereka kepada mereka yang berhak mendapatkannya dan kepada pemimpin hendaklah ia berlaku adil dalam memutuskan perkara-perkara yang terjadi pada rakyatnya ${ }^{4}$, dan kemudian pada ayat yang ke 59 adalah berisi perintah Allah kepada rakyat, agar mereka mentaati Allah dan Rasul-Nya

\footnotetext{
${ }^{1}$ Departemen Agama RI, Al-Qur'an dan Terjamahannya, Cet. Majma' al-Malik Fahd Tahun 1435H, Madinah Munawwarah KSA

${ }^{2}$ Ibid.

${ }^{3}$ Ibnu Katsir, Tafsir Ibnu Katsir (1/709), Ibnu Kastir adalah Ismail bin Umar al-Quraisyi bin Katsir al-Bashri al-Dimasyqi Imaduddin Abu al-Fida al-Hafizh al-Muhaddits al-Syafi'i, Penerbit Jam'iyyah Ihyâ' al-Turâts al-Islâmy, Cetakan V, Tahun 1421H/2001M, Kuwait ${ }^{4}$ Ibid.
} 
shalallâhu 'alaihi wa-sallam dengan menjalani perintah-perintah Allah dan RasulNya dan menjauhi larangan-larangan keduanya, kemudian perintah Allah kepada rakyat agar mereka mentaati pemimpin mereka yang mentaati Allah dan RasulNya shalallâhu 'alaihi wa-sallam, dan mereka tidak boleh ta'at kepada pemimpin mereka dalam bentuk kemaksiatan ${ }^{5}$

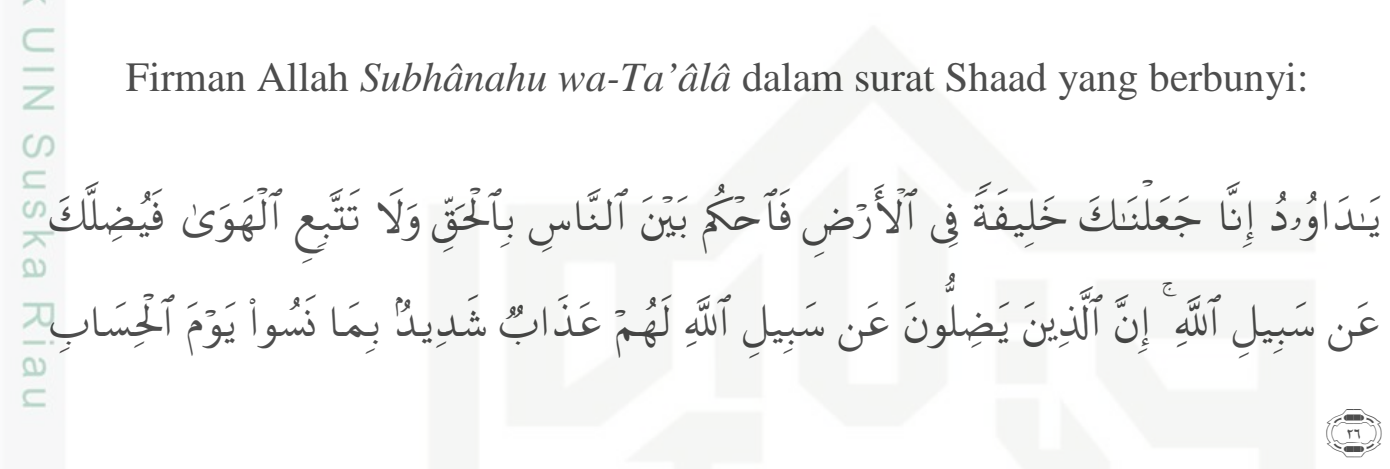

"Hai Daud, sesungguhnya Kami menjadikan kamu khalifah (penguasa) di muka bumi, maka berilah keputusan (perkara) di antara manusia dengan adil dan janganlah kamu mengikuti hawa nafsu, karena ia akan menyesatkan kamu dari jalan Allah. Sesungguhnya orang-orang yang sesat dari jalan Allah akan mendapat azab yang berat, karena mereka melupakan hari perhitungan” (QS Shaad/38, ayat 26) ${ }^{6}$

Ayat ini merupakan wasiat Allah kepada para pemimpin yang memegang kekuasaan agar mereka berlaku adil kepada manusia dalam menjalankan roda pemerintahannya dengan berpedomankan kepada ajaran-ajaran yang diturunkan oleh Allah dan jangan sekali-kali berpaling dari syari'at Allah, kalau kalian berpaling dari syari'at-Nya maka pasti Dia (Allah) akan menyesatkan kalian dari jalan-Nya, orang-orang (yaitu para pemimpin) yang menyimpang dari jalan-Nya maka Allah menjanjikan untuk mereka hisab yang berat dan azab yang pedih di hări kiamat kelak.

${ }^{5}$ Ibnu Katsir, Tafsir Ibnu Katsir (1/712)

${ }^{6}$ Departemen Agama RI, Al-Qur'an dan Terjamahannya. 
Berkenanan dengan ayat ini, (seorang Amirul Mukminin) bernama AlWalid bin Abdu al-Malik berkata kepada Abu Zur'ah: “Apakah seorang khalifah akan dihisab pada hari kiamat kelak" ? Maka Abu Zur'ah menjawab: "Wahai Amirul Mukminin, apakah anda lebih mulia daripada Nabi Daud 'alaihi salâm...?, sedangkan Nabi Daud itu, Allah kumpulkan pada dirinya kemuliaan sebagai seorang Nabi dan ia juga seorang khalifah, maka tetap Allah menjanjikan Z

kepadanya untuk hisab yang berat dan azab yang pedih (apabila dia tidak menjalankan syari' at Allah dalam kepemimpinannya). ${ }^{7}$

Nabi Muhammad shalallâhu 'alaihi wa-sallam, ia senantiasa mewantiwanti ummatnya agar mereka benar-benar memperhatikan masalah yang sangat urgent ini, sebagaimana dalam riwayat-riwayat berikut ini;

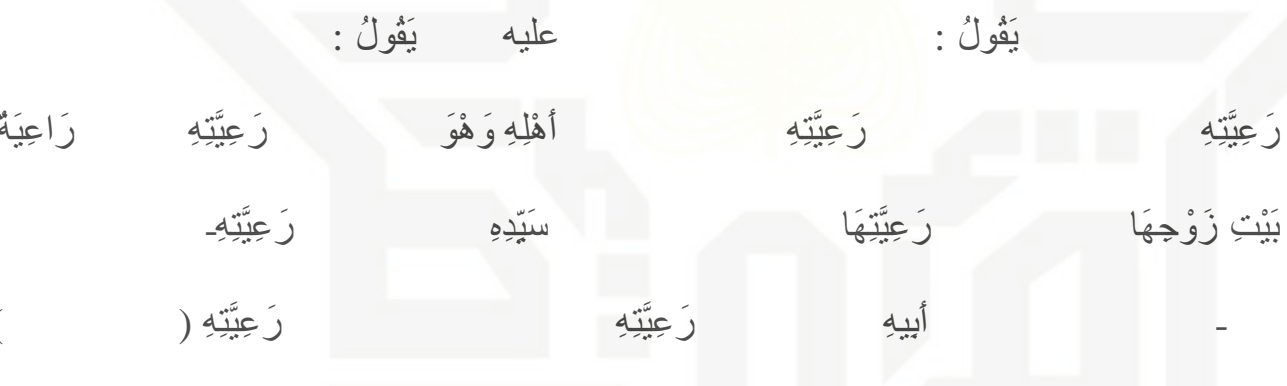

Dari Ibn umar radhiyallahu 'anhuma dia berkata: saya mendengar Rasulullah shalallâhu 'alaihi wa-sallam bersabda : "Setiap kalian adalah pemimpin dan kălian akan diminta pertanggungjawaban atas kepemimpinannnya. Seorang kepala negara adalah pemimpin atas rakyatnya dan dia akan diminta pertanggungjawaban perihal rakyat yang dipimpinnya. Seorang suami adalah pemimpin atas anggota keluarganya dan akan ditanya perihal keluarga yang dipimpinnya. Seorang isteri adalah pemimpin atas rumah tangga dan anakanaknya dan akan ditanya perihal tanggung jawabnya. Seorang

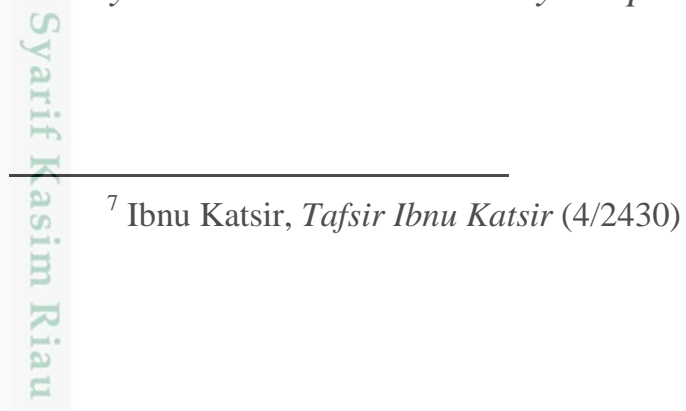


pembantu/pekerja rumah tangga adalah bertugas memelihara barang milik majikannya dan akan ditanya atas pertanggung-jawabannya. Dan kamu

(1)

sekalian pemimpin dan akan ditanya (diminta pertanggungan jawab) darihal hal yang dipimpinnya" (HR. Al-Bukhari) ${ }^{8}$.

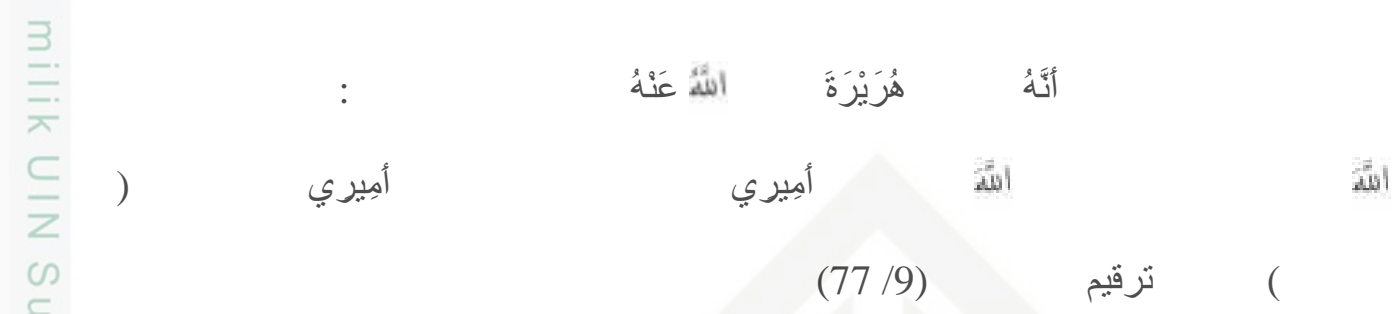

Abu Salamah bin Abdur al Rahman berkata bahwa sesungguhnya saya telah - mendengar Abu Hurairah berkata: Sesungguhnya Rasulullah shalallâhu ‘alaihi wa-sallam beliau berkata: “Barangsiapa yang mentaatiku maka dia telah mentaati Allah, barangsiapa yang bermaksiat kepadaku maka dia juga berbuat maksiat Allah dan barangsiapa yang berbuat maksiat kepada pemimpinku (yang aku angkat untuk kalian) maka berarti dia bermaksiat kepadaku. (HR. Al-Bukhari) ${ }^{9}$

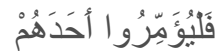

عن أبي سعيد الخدري رضي الله عنه أن رسول الله

Dari Abu Sa'id Al-Khudri radhiyallâhu 'anhu, Bahwa Rasulullah shalallâhu 'alaihi wa-sallam beliau berkata: "Apabila ada tiga orang bepergian, hendaknya mereka mengangkat seseorang di antara mereka sebagai pemimpinnya" (HR. Abu Daud). ${ }^{10}$

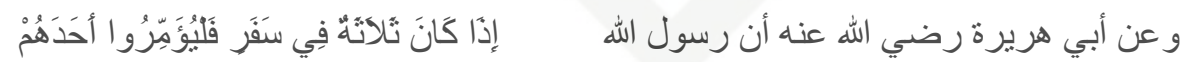

Dari Abu Hurairah radhiyallâhu 'anhu, Bahwa Rasulullah shalallâhu 'alaihi wa-sallam beliau berkata: "Jika ada tiga orang bepergian, hendaknya mereka $\underset{i n}{\circ}$

${ }^{8}$ Al-Bukhari, Shahih al-Bukhâri (No. 893, 2409, 2554) oleh Abu Abdillah Muhammad bin Ismail bin Ibrahim bin al-Mughirah bin Bardizbah al-Ju'fi al-Bukhari, lahir di Bukhara 13 Syawal 194 H / 21 Juli 810, wafat di Khartank 1 Syawal 256 H /1 September 870), Penerbit Dar Ibnu Katsir, Cet. Tahun 1423H /2003M, Damaskus Bairut,

${ }^{9}$ Al-Bukhari, Shahih al-Bukhâri (No. 7137)

${ }^{10}$ Abu Daud, Sunan Abi Daud (Bab 85, No. 2608, Juz 4 Hal. 249 ) Oleh Al-Imam al-Hafizh Abu Dawud Sulaiman bin al-Asy'ats al-Sijistani (202-275H/817-889M). Penerbit Dar al-Risalah al-A Alamiyah, Tahun 1430H/2009M, Bairut Libanon. 
mengangkat salah seorang di antara mereka sebagai pemimpinnya” (HR. Abu Daud) ${ }^{11}$

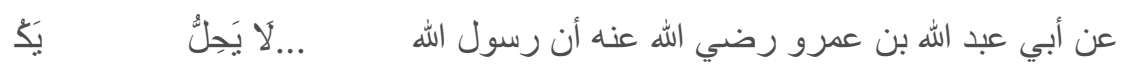<smiles>[AlH2]</smiles>

Dari Abu Abdullah bin Amar radhiyallâhu 'anhu, Bahwa Rasulullah shalallâhu 'alaihi wa-sallam berkata: "Tidak dihalalkan (dibolehkan) bagi ¿tiga orang yang berada di suatu tempat, kecuali mereka mengangkat salah ¿ seorang dari mereka sebagai pemimpin mereka” (HR. Imam Ahmad). ${ }^{12}$

Berdasarkan ayat-ayat dan hadits-hadits diatas, hal itu menunjukkan bahwa Allah dan Rasul-Nya telah memberikan gambaran secara terang dan jelas bahwa syari'at Islam itu sangat memandang penting persoalan seorang pemimpin dalam bermasyarakat, berbangsa dan bernegara. Dalam permasalahan ini Nabi shalallâhu 'alaihi wa-sallam telah memberikan intruksi kepada ummat Islam agar mereka memperhatikan permasalahan kepemimpinan ini walaupun hanya dalam sebuah kelompok kecil masyarakat seperti dalam melakukan perjalanan, maka Nabi kita shalallâhu 'alaihi wa-sallam memerintahkan agar diangkat seseorang untuk pemimpinnya dan tentunya sosok seorang pemimpin itu lebih urgent untuk क

diangkat seorang pemimpin dalam memimpin masyarakat yang banyak.

Demikian juga peristiwa sejarah pembaiatan terhadap Abu Bakar AsShiddiq radhiyallâhu 'anhu, di Saqifah Bani Saidah sesaat pasca wafatnya $\stackrel{\infty}{*}$ Räsulullah shallâllahu 'alaihi wa sallam, ini adalah bukti nyata lainnya betapa $\stackrel{\circ}{\circ}$ pentingnya arti kepemimpinan itu dalam Islam, bisa dibayangkan oleh kita pada bS

11 Ibid.

${ }^{12}$ Ahmad bin Hambal, Musnad al-Imam Ahmad bin Hambal (2/176) beliau adalah Ahmad bin Muhammad bin Hambal bin Hilal bin Asad al Marwazi al Baghdadi/Ahmad bin Muhammad bin Hambal dikenal juga sebagai Imam Hambali (164-241H), Penerbit/Cet. Maktabah Dar al-lslam KSU, Cetakan Pertama Tahun 1434H 
saat jasad Rasulullah shallâllahu 'alaihi wa sallam, masih terbujur kaku dan bełum dikebumikan, justru para sahabat terlebih dahulu bermusyawarah untuk memilih khalifah pengganti Nabi shallâllahu 'alaihi wa sallam, sedangkan prosesi menyelenggarakan jenazah beliau yang agung dan mulia adalah kebutuhan yang sangat mendesak untuk disegerakan, karena hukum menyelenggarakannya itu adalah wajib disegerakan, namun demikian para shahabat menangguhkannya agar z

kepemimpinan kaum muslimin tidak mengalami kepakuman.

Karena begitu sangat urgensinya tentang masalah kepemimpinan ini dalam tatanan kehidupan bermasyarakat, berbangsa dan bernegara maka ungkapanungkapan indah Ibnu Taimiyyah dalam hal ini banyak menjadi rujukan, diantara riwayat yang ia ungkapkan adalah sebagai berikut:

"Sesungguhnya pemimpin itu adalah bayangan Allah di muka bumi ini"13

Dalam ungkapan lainnya ia berkata;

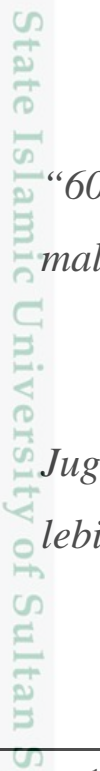

13. Ibnu Taimiyyah, Al-Siyâsah al-syar'iyyah fî islâhi al-râ'iy wa al-ra'iyyah, Hal. 217. Oleh Taqiyu al-Dîn Abu al-Abâs Ahmad bin Abdul Halim bin Taimiyyah al-Harâny, Cetakan Dâru al-Ma'rifah Jumlah 1 Jilid

14. Ibid.

15. Ibid. 
Yang melatar belakangi penulis untuk menulis tesis tentang kepemimpinan nōn Muslim ditengah mayoritas masyarakat muslim, agar setiap elemen masyarakat muslim sadar, bahwa masalah yang banyak disinggung dalam syariat Islam adalah persoalan kepemimpinan non Muslim. Al-Quran dan al-Sunnah telah memberikan begitu banyak tuntunan dan petunjuk kepada kaum Muslimin agar kaum muslimin tidak salah dalam memilih figur seorang pemimpin. Suatu hal z yáng pasti dalam permasalahan ini adalah bahwa al-Quran dan al-Sunnah serta Ijma' ulama Islam telah menjelaskan dengan sangat terang tentang sikap yang harus dipegang erat-erat oleh kaum muslimin dalam menentukan pilihan, yaitu apabila ada calon pemimpin mereka dari kalangan non-Muslim, maka sikap yang mesti mereka ambil adalah menolak calon pemimpin non Muslim tersebut dan tidak akan memilihnya, kenapa kaum muslimin mesti bersikap demikian... ?, jawaban adalah karena Allah dan Rasul-Nya yang telah memerintahkan kita kaum muslimin untuk bersikap seperti itu. ${ }^{16}$

Kaum muslimin itu hendaklah menyadari, bahwa urusan memilih seorang pemimpin itu bukan hanya urusan dimensi duniawi semata, akan tetapi masalah memilih pemimpin itu juga menyangkut dimensi akidah dan $u k h r o w i$. Oleh karena itu seorang mukmin tidak selayaknya berpaling dari petunjuk al-Qur'an dan alSưnnah dalam menghadapi berbagai masalah mereka. Ketika seorang muslim dihadapkan dihadapanya ada dua calon pemimpin, salah seorangnya muslim dan

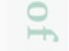
yang satunya lagi non muslim, maka seorang muslim itu tidak punya pilihan kecuali dia harus memilih saudaranya yang seiman, kalau hal itu tidak dia

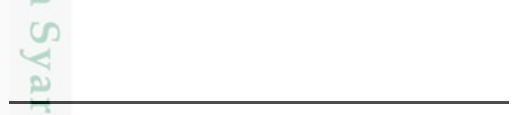

${ }^{16}$ Sholeh Fauzan, Kitab Tauhid Jilid I, oleh Dr. Sholeh bin Fauzan bin Abdullah al-Fauzan. Diterjemahkan oleh Agus Hasan Bashori, Lc. MA. Penerbit Darul Haq Cet. XXIV Tahun 2015, Hâl. $145-147$ 
lakukannya tapi justru dia menjatuhkan pilihannya kepada non Muslim, maka berarti dia sudah salah dalam melangkah dan sebagai konsekwensinya paling tidak ada dua, pertama duniawi adalah dia akan merasakan pahit getirnya kehidupan sosial dan religinya karena cahaya agamanya tidak akan bersinar lagi datam denyut kehidupan mereka bermasyarakat, berbangsa dan bernegara sebab masalah kehidupan mereka itu diatur oleh seorang non Muslim dengan kekuasaan dan kewenangan yang ada padanya, dan konsekwensi kedua adalah konsekwensi o ukhrawi adalah berarti dia telah menggadaikan dan menjual aqidahnya dengan harga yang sangat murah yaitu aqidah al-wala wa al-bara yaitu seorang mukmin itu wajib bersikap loyalitas kepada sesama mukmin dan kebalikkannya bahwa seorang mukmin tidak boleh bersikap loyalitas kepada non Muslim. ${ }^{17}$ Sebagai contoh konkritnya adalah ketika dihadapan seorang mukmin itu pada dua pilihan antara memilih seorang Muslim atau memilih non Muslim, maka pada saat itu seorang mukmin itu wajib baginya untuk memilih saudaranya yang sama-sama beriman untuk menjadi pemimpinnya walaupun padanya ada sisi kekurangannya. Dän seorang mukmin itu tidak boleh dia menjatuhkan pilihannya kepada non Muslim, walaupun dia memiliki kelebihan-kelebihan dibandingkan yang lain, 3 .

sikap seperti inilah yang wajib dipegang oleh seorang mukmin, sebab agama Islam itu telah mengajarkan kepada kita untuk bersikap tegas dan jelas dalam masalah memilih seorang pemimpin.

Perhelatan pilakada DKI Jakarta tahun 2017 yang lalu telah menyedot perhatian yang sangat luas, hal ini bukan karena posisi DKI Jakarta sebagai ibu kota negara, melainkan karena disebabkan ada calon incumbent dari non-Muslim

${ }^{17}$ Sholeh Fauzan, Kitab Tauhid Jilid I, Hal. 145 - 147. 
yaitu Basuki Tjahaya Purnama alias Ahok, dia ini menjadi rival bagi ummat Islam dătam Pilkada tersebut. Maka tentunya dalam hal ini memunculkan sikap pro dan kontra tentang kepemimpinan non-Muslim di tengah-tengah penduduk yang mayoritas Muslim ${ }^{18}$. Maka pada saat itu muncul orang-orang yang "pasang bädan" dari kalangan ummat Islam yang membela kepemimpinan non-Muslim, mereka ini telah membukakan pintu yang selebar-lebarnya bagi non-Muslim untuk bisa menjadi pemimpin atas kaum Muslimin, demi mencapai tujuan $\stackrel{c}{c}$ tersebut merekapun membawakan alasan yang keliru dan argumentasi yang sangat lemah seperti sarang laba-laba, namun mereka ini pada sisi yang lain berusaha menolak ayat-ayat Al-Qur'an dan teks-teks al-hadits yang jelas-jelas melarang umat Islam untuk memilih pemimpin dari kalangan orang non Muslim, dan ketika nash-nash yang terang benderang seperti matahari disiang bolong itu, maka dengan serta merta mereka mengatakan bahwa nash-nash yang melarang memilih pemimpin non Muslim itu tidak tegas alias masih samar-samar. Lalu dengan bangganya mereka berargumentasi dengan perkataan Ibnu Taimiyyah yang terdapat dalam bukunya al-Hisbah ${ }^{19}$ :

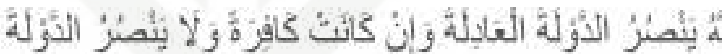

“Allah senantiasa menolong negeri yang adil sekalipun negeri itu adalah negeri kafir, dan Dia tidak akan menolong negeri yang zalim sekalipun negeri itu adalah negeri yang beriman.”

证

Berargumentasi dengan perkataan Ibnu Taimiyyah ini demi menegakkan pendapat mereka yang membolehkan seorang muslim untuk memilih non Muslim

${ }^{18}$ Dede Rodin, Kepemimpinan Non Muslim Dalam Perspektif Al-Qur'an, Jurnal Keilmuan Tafsir Hadis Volume 7, Nomor 1, Juni 2017. Penerbit Mutawâtir, Universitas Islam Negeri (UIN) Walisongo Semarang dederodin@walisongo.ac.id

${ }^{19}$ Ibnu Taimiyyah, Al-Hisbah hal. 04, Oleh Taqiyu al-Dîn Abu al-Abâs Ahmad bin Abdul Hâlim bin Taimiyyah al-Harâny, (versi Maktabah Syamilah) 
menjadi pemimpin dikalangan mayoritas kaum muslimin, hal ini tentu tidaklah tepat sama sekali, sebab berargumen dengan hal ini memiliki beberapa titik kelemahan, titik kelemahan yang pertama adalah bertentangan dengan ayat-ayat al-Qur'an, titik kelemahan yang kedua adalah bertentangan dengan nash-nash alHadits, titik kelemahan yang ketiga adalah bertentangan Ijma' ulama serta titik kelemahan yang keempat adalah tidak ada relevansinya antara perkataan Ibnu Taimiyyah itu dengan kebolehan memilih pemimpin non Muslim, karena o perkataan Ibnu Taimiyyah itu hanya berbicara tentang urgensi keadilan dalam bernegara, ungkapan Ibnu Taimiyyah tidak menyinggung masalah memilih pemimpin atau kepemimpinan.

Sehingga argumentasi mereka ini sebenarnya sangatlah lemah dan rapuh, mereka ini diumpamakan oleh Allah dengan "sarang laba-laba" sebagaiman dalam surat al-'Ankabut

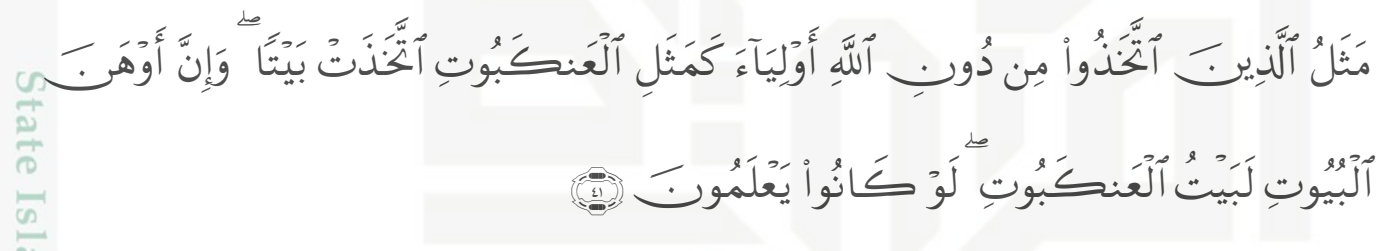

Perumpamaan orang-orang yang mengambil pelindung-pelindung selain Allah adalah seperti laba-laba yang membuat rumah, dan sesungguhnya rumah yang paling lemah itu adalah rumah laba-laba kalaulah mereka "mengetahui" (QS. Al-Ankabut/29:41) ${ }^{20}$

Dr. Shalah al-Shawi di dalam al-Wajiz ${ }^{21}$, beliau menyebutkan : bahwa syarat mutlak seorang calon pemimpin itu (dalam Islam) adalah "muslim", persyaratan semacam ini merupakan sesesuatu hal yang mudah dimengerti dari $\stackrel{20}{20}$ Departemen Agama RI, Al-Qur'an dan Terjamahannya

${ }^{21}$ Al-wajîz fî fiqhi al-khilâfah, Oleh Syekh Dr. Sholeh al-Showy, Penerbit Dar al-'Ilam alDual, Tanpa Tahun Terbitan, Hal. 22 
hukum Islam

). Dan juga ia mengatakan bahwa salah

satu tugas seorang pemimpin adalah menegakkan agama Islam (إقامة الدين الإسلامي).

Lalu bagaimana mungkin hal itu dapat dijalankan oleh orang kafir yang tidak beriman terhadap ajaran Islam itu sendiri? Ini adalah sesuatu hal yang mustahil.

Hal ini juga diungkapkan oleh seorang tokoh mazhab Al-Maliki yaitu alQadhi Iyadh, ia mengatakan

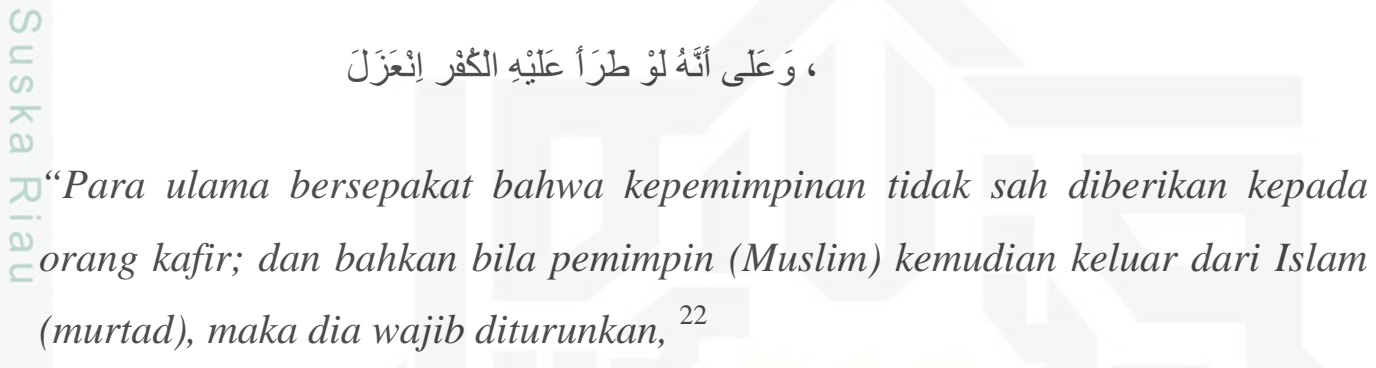

Ibnu Hazm juga menyatakan ijma ulama tentang permasalahan ini, ia berkata:

"Para Ulama telah sepakat bahwa masalah kepemipinan tidak boleh diserahkan kepada wanita, non Muslim dan anak-anak” 23

I Ihab Kamal Ahmad setelah menukilkan pernyataan Ibnu Hazm dalam masalah ini, ia mengungkapkan bahwa Ibnu Taimiyyah tidak pernah menyelisihi $\ddot{2}$

konsensus Ulama dalam masalah ini dan bahkan Ibnu Taimiyyah justru sepakat ב. menyatakan (bahwa masalah ini adalah) Ijma' 24

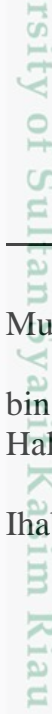

22 Al-Nawawi, Al-Minhaj syarhu shahih muslim (6/314), dia adalah Abu Zakaria Muhyuddin bin Syaraf An-Nawawy (631-24 Rajab 676H), Masdar Kitab: Mauqi’ al-Islam

${ }^{23}$ Ibnu Hazm, Maratib al-ijma' oleh Abu Muhammad Ali bin Ahmad bin Sa'id bin Hazm bin Ghalib bin Sholeh bin Khalaf bin Ma'dan bin Sufyan bin Yazid Al-Farisi (384-Sya'ban 456H), Hal. 208.

${ }^{24}$ Ihâb Kamal, Al-raddu al-mubîn 'alâ man ajâza wilâyati al-kâfir 'alâ al-muslimîn, oleh Ihab Kamal Ahmad, https://www.alukah.net/sharia/0/30280 (link tanggal 15 Mei 2019) 
Ibnu Hajar al-Asqolani juga menyatakan ijma ulama tentang perkara ini di dātam kitabnya Fathu al-Baari ${ }^{25}$, beliau rahimahullah berkata:

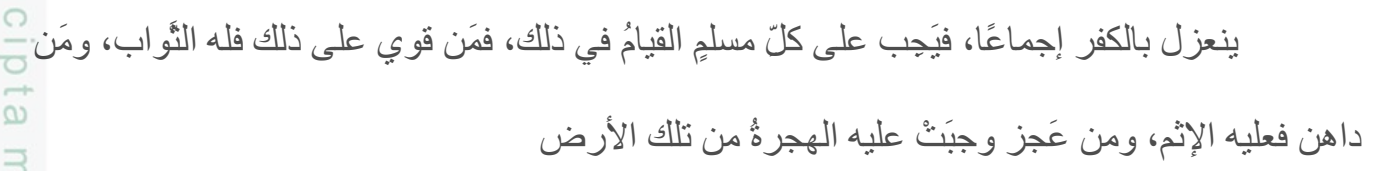

“ "Sesungguhnya telah ada konsensus ulama bahwa seorang pemimpin itu $\underset{z}{\beth}$ wajib) dilengserkan karena sebab kekufurannya, maka wajib atas setiap cpribadi muslim untuk melakukan hal itu, barangsiapa yang mampu melakukan hal itu maka dia memperoleh ganjaran pahala, dan barangsiapa yang berpura-pura (taat kepadanya) maka dia menanggung dosa, dan barangsiapa yang tidak punya kemampuan untuk hal itu maka dia mesti hijrah dari negeri tersebut.

Beralasan dengan ungkapan Ibnu Taimiyyah dalam karyanya al-Hisbah ${ }^{26}$ :

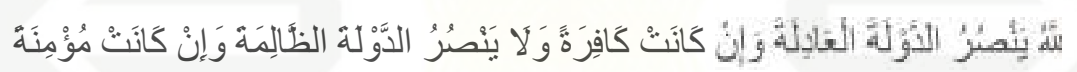

"Allah senantiasa menolong negeri yang adil sekalipun negeri itu adalah negeri kafir, dan Dia tidak akan menolong negeri yang zalim sekalipun negeri - itu adalah negeri yang beriman."

Pertama: Apakah benar Ibnu Taimiyyah membolehkan kepemimpinan non Muslim untuk dipilih atau diangkat sebagai pemimpin bagi kaum muslimin ?

Hal itulah yang mendorong penulis untuk mengangkat tema "Kepala Negara Non Muslim Menurut Ibnu Taimiyyah”, sehingga penulis berusaha menjelaskan pandangan-pandangan politik Ibnu Taimiyyah rahimahullah, diantaranya adalah tentang masalah kepemimpinan dalam dalam perspektif syari'at Islam, kemudian penulis juga menjelaskan tentang syarat-syarat kepemimpinan dalam Islam

\footnotetext{
${ }^{25}$ Ibnu Hajar al-Asqalâni, Fathu al-Bâri (123/13). Syihabuddin Abul Fadhl Ahmad bin Ali bin Muhammad bin Muhammad bin Ali bin Mahmûd bin Ahmad bin Hajar, dan mashur dengan sebutan Penerbit Daru al-Ma'rifah, Bairut Th. 1379H

${ }^{26}$ Ibnu Taimiyyah, Al-Hisbah hal. 04.
} 
menurut pandangan para Ulama dan juga menurut pandangan Ibnu Taimiyyah răhimahullah, kemudian juga penulis menjelaskan pandangan Ibnu Taimiyyah rahimahullah terhadap kepemimpinan non Muslim ditengah kaum muslimin sebagai pokok bahasan utama, serta yang penulis juga menyertakan pandangan penulis sendiri atas penelitian ini yang penulis dapatkan dari pandanganpandangan Ibnu Taimiyyah dan ulama-ulama yang lainnya, kemudian terakhir penulis memberikan sedikit bantahan-bantahan terhadap mereka yang mengklaim co bāhwa Ibnu Taimiyyah adalah termasuk ulama yang membolehkan kepemimpinan non-Muslim ditengah mayoritas kaum muslimin.

\section{B. Fokus Penelitian}

\section{Identifikasi Masalah}

Mengidentifisikasikan permasalahan adalah salah satu aspek yang sangat penting dalam melakukan penelitian terhadap bidang apa saja, jadi identifisikasi masalah itu adalah teori dalam mengenali dan menganalisis masalah dan bagaimana menginventarisir masalah tersebut. Beranjak dari latar belakang diatas maka dapat diidentivikasi beberapa masalah sebagai berikut;

a. Menganalisa konsep kepemimpinan menurut syari'at Islam.

b. Menganalisa dalil-dalil baik dari al-Qur'an maupun as-Sunnah dalam masalah kepemimpinan.

c. Menganalisa dalil-dalil baik dari al-Qur'an dan as-Sunnah serta Ijma' ulama dalam masalah kepemimpinan non Muslim di tengah masyarakat Islam.

d. Mentela'ah syarat-syarat kepemimpinan dalam Islam menurut pandangan para ulama dan juga pandangan kepemimpinan menurut Ibnu Taimiyyah. 


\section{Batasan Masalah}

Penulis membuatkan batasan masalah tujuannya adalah agar permasalahan yang penulis akan tuangkan ini terarah dan tidak melebar kemana-mana serta tidak terlalu luas jangkauannya, maka permasalahan yang penulis teliti dan telaah hanyalah terfokus pada masalah-masalah yang berkaitan dengan tema tesis yang penulis buat ini yaitu : “Kepala Negara Non Muslim Menurut Ibnu Taimiyyah"

\section{Rumusan Masalah}

Dalam merumuskan permasalahan yang penulis tuangkan dalam tesis ini, maka penulis memberikan beberapa poin penting, yaitu sebagai berikut:

1) Bagaimana kepala negara menurut pandangan Ibnu Taimiyyah.

2) Apa dasar pemikiran Ibnu Taimiyyah dalam persyaratan seorang calon pemimpin.

3) Bagaimana pandangan Ibnu Taimiyyah tentang masalah kepemimpinan Non Muslim.

4) Apa relevansinya pendapat Ibnu Taimiyyah dengan zaman sekarang.

\section{Tujuan Penelitian dan Kegunaan Penelitian}

\section{a. Tujuan Penelitian.}

Berdasarkan Rumusan Masalah diatas, maka Tujuan penelitian ini adalah :

1) Memahami dan menjelaskan konsep kepala negara menurut pandangan Ibnu Taimiyyah.

2) Mengerti tentang bagaimana pandangan Ibnu Taimiyyah tentang non Muslim yang memimpin kaum Muslimin. 


\section{b. Manfaat Penelitian.}

Adapun manfaat yang penulis sampaikan melalui penelitian ini adalah sebagai berikut:

1) Bersifat teoritis dengan harapkan agar hasil penelitian ini dapat menjadi penyumbang pemikiran dibidang ilmu hukum Islam, khususnya ilmu hukum Islam tentang masalah kepemimpinan baik dalam bernegara dan berbangsa, yang tentunya harus sesuai dengan al-Qur'an dan as-Sunnah

2) Bersifat praktis dengan harapan agar hasil penelitian ini bisa dimanfaatkan oleh setiap kalangan, baik pelaksana hukum Islam secara bernegara maupun bermasyarakat.

3) Bagi penulis, selain untuk memenuhi syarat dalam menyelesaikan program strata dua (S-2) pada bidang Magister Hukum Islam, juga untuk memperluas cakrawala berpikir mengenai konsep Islam dalam masalah kepemimpinan dalam Islam dan juga bisa jelas dan tegas dalam memecahkan masalah kepemimpinan non Muslim.

4) Bagi masyarakat, diharapkan menjadi referensi bagi mereka guna memahami urgensi kepemimpinan dalam kehidupan bermasyarakat.

5) Bagi kalangan akademisi, dapat menambah wawasan dan khazanah intelektual dan muda-mudahan menjadi ide baru bagi kalangan insan akademik untuk membuat penelitian yang lebih baik dan lebih berkualitas.

\section{Sistematika Penulisan}

Dalam mencari jawaban atas asas pokok permasalahan diatas, maka penulisan tesis ini dibagi menjadi lima bab, dengan keterangan ringkasnya adalah

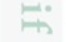
sebagai berikut: 
Bab Pertama: berupa pendahuluan, yang terdiri dari latar belakang masalah, fokus masalah yang memuat identifikasi masalah, batasan masalah dan rumusan masalah, selain itu dalam bab ini juga disertakan memuat tujuan masalah, manfaat penelitian dan sistematika penulisan. Bab ini merupakan kerangka berpikir dan kerangka kerja yang akan dilaksanakan dalm menyelesaikan penelitian ini.

Bab Kedua, bab ini membahas tentang landasan teori tentang kêpemimpinan, definisi pemimpin dan pengertiannya, dasar-dasar kepemimpinan dalam Islam, macam-macam kepemimpinan dalam Islam, dasar-dasar hukum kepemimpinan non Muslim dalam Islam, kepemimpinan non Muslim dalam alQur'an, dalam as-Sunnah dan Ijma' ulama, dan juga dalam bab ini memuat tentang kriteria seorang pemimpin menurut ulama selain Ibnu Taimiyyah serta biografi Ibnu Taimiyyah termuat dalam bab ini.

Bab Ketiga, dalam bab ini penulis memuat beberapa hal yaitu jenis dan pendekatan penelitian, kemudian sifat penelitian, setelah itu penulis menjelaskan sumber bahan dan penggalian data serta penulis juga memuat dalam bab ini bagaimana mengolah dan menyajikan data serta melakukan analisis data.

Bab Keempat, pada bab ini penulis mengetengahkan beberapa hal, dan bab ini adalah inti daripada tesis ini, beberapa hal tersebut adalah: apa pengertian kepala negara menurut Ibnu Taimiyyah, apa syarat-syaratnya seseorang itu boleh diangkat menjadi menurut Ibnu Taimiyyah, kemudian bagaimana sebenarnya kepemimpinan non Muslim menurut pandangan Ibnu Taimiyyah serta apa relevansinya pendapat Ibnu Taimiyyah dengan zaman sekarang. 
Bab Kelima, pada bab kelima ini penulis hanya membuat dua point (2) penting, salah satunya kesimpulan dari tesis ini dan yang kedua adalah saran-saran yang membangun yang penulis harapkan pelbagai pihak, dengan harapan semoga tesis menjadi kontribusi yang positif bagi banyak kalangan, baik masyarakat 3 secara umum maupun kalangan akademika secara khusus. 


\section{BAB II}

\section{LANDASAN TEORI}

Kepemimpinan

\section{1) Pengertian Kepemimpinan}

Kata pemimpin di dalam bahasa Arab mempunyai beberapa istilah yaitu Imam, Khalifah, Amir, Malik dan Sulthan. Imam menurut bahasa berasal dari kata (Amma-ya'ummu-imâman) yang berarti ikutan bagi kaum ${ }^{1}$ dan berarti setiap orang yang diikuti oleh kaum yang sudah berada pada jalan yang benar ataupun mereka yang sesat. Imam juga bisa diartikan sebagai "pemimpin”, seperti "ketua" atau yang lainnya. Kata imam juga digunakan untuk orang yang mengatur kemaslahatan sesuatu, untuk pemimpin pasukan, dan untuk orang dengan fungsi lainnya $^{2}$

Allah berfirman :

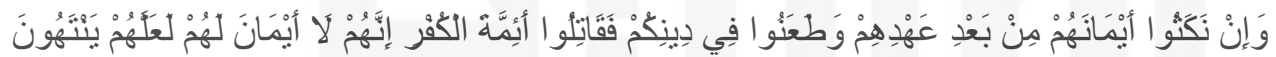

Jika mereka merusak sumpah (janji)nya sesudah mereka berjanji, dan mereka mencerca agamamu, maka perangilah pemimpin-pemimpin orang-orang kafir itu, karena sesungguhnya mereka itu adalah orang-orang (yang tidak dapat dipegang) janjinya, agar supaya mereka berhenti. (QS. Al-Taubah/9 ayat : 12) ${ }^{3}$

Imam juga berarti orang yang diikuti oleh suatu kaum. Kata imam lebih banyak digunakan untuk orang yang membawa pada kebaikan. Di samping itu, kata-kata imam sering dikaitkan dengan shalat. Oleh karena itu di dalam

${ }^{1}$ Mahmud Yunus, Kamus Arab-Indonesia Mahmud Yunus, (Jakarta: Mahmud Yunus Wa Dzurriyyah, 1999), hal. 428.

${ }^{2}$ Ali Al-Salus, Imamah dan khalifah, (Jakarta: Gema Insan Press, 1997), hal. 15.

${ }^{3}$ Departemen Agama RI, Al-Qur'an dan Terjamahannya 
kepustakaan Islam sering dibedakan antara imam yang berkedudukan sebagai kepala negara atau yang memimpin umat Islam dan imam dalam arti yang mengimami shalat. Untuk yang pertama sering digunakan istilah al-Imamah alUdhma atau al-Imamah al-Kubra sedangkan untuk yang kedua sering disebut alImamah al-Shugra. Biasanya kata-kata imam hanya digunakan untuk menyebut seseorang yang memimpin di dalam bidang agama. ${ }^{4}$

Kata khalifah sering diartikan sebagai pengganti, karena orang yang menggantikan itu berada atau datang sesudah orang yang digantikan dan ia menempati tempat dan kedudukan orang tersebut. Khalifah juga bisa berarti seseorang yang diberi wewenang untuk bertindak dan berbuat sesuai dengan ketentuan-ketentuan orang yang memberi wewenang. ${ }^{5}$

Allah Ta'ala berfirman

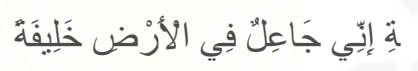

Dan (ingatlah) ketika Tuhanmu berkata kepada Malaikat 'sesungguhnya Aku akan menjadikan pemimpin di muka bumi... (QS. Al-Baqarah/2 ayat : 30) ${ }^{6}$

Amir berasal dari kata (Amara-ya'muru-amran) yang artinya menyuruh, lawan kata dari melarang dan berasal dari kata yang berarti bermusyawarah. Secara istilah berarti orang yang memerintah dan dapat diajak bermusyawarah ${ }^{7}$. Kata-kata amir dengan arti pemimpin tidak ditemukan di dalam al-Qur'an, walaupun kata-kata "amara" banyak ditemukan di dalam al-Qur' an. Istilah amir

${ }^{4}$ A. Djazuli, Fiqh Siyasah Implementasi Kemaslahatan Umat dalam Rambu-rambu Syariah (Jakarta: Kencana Prenada Media Grup, 2003), hal. 54.

${ }^{5}$ Taufiqi Rahman, Moralitas Pemimpin dalam Perspektif al-Quran, (Bandung: CV Pustaka Setia, 1999), hal. 21.

${ }_{-3} \quad{ }^{6}$ Departemen Agama RI, Al-Qur'an dan Terjamahannya

${ }^{7}$ Louis bin Nakula Dhahir Ma'luf, al-Munjid fi al-lughah wa al-a'lam, (Beirut: Dâr alMachreq sarl Publishers, 2000), hal. 344. 
dengan arti pemimpin hanya popular di kalangan sahabat. Hal ini terbukti pada saat para sahabat bermusyawarah di Tsaqifah Bani Sa'adah untuk menentukan pengganti Nabi, para sahabat Anshar berkata "Dari kami ada seorang Amir dan dari Tuan-tuan juga ada seorang Amir". Selain itu, istilah amir juga pernah digunakan oleh Umar bin Khattab ketika menjadi sebagai khalifah menggantikan Abu Bakar. ${ }^{8}$

Tentang istilah amir itu ada dalam ungkapan seorang sahabat Nabi

$$
\text { وَهْهَ أمِيرُ المَدَينَةِ }
$$

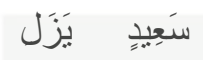

Abu Sa'id berkata: manusia senantiasa pada hal yang demikian itu, hingga aku keluar bersama Marwa, yaitu pemimpin Madinah pada hari Idul Adha atau Idul Fitri. (HR. Al-Bukhari) ${ }^{9}$

Istilah selanjutnya yang menunjukkan kepada pemimpin adalah kata Malik. Malik secara bahasa berasal dari kata (malaka-yamliku-milkan-malkanmulkan-malakatan-mamlakatan) yang berarti memiliki atau mempunyai sesuatu. Atau dapat pula berarti pemilik perintah dan kekuasaan pada suatu bangsa, suku c) atau negeri. ${ }^{10}$

Sulthan secara bahasa berarti Malik (Raja) atau wali, Rasulullah shallallahu 'alaihi wasallam menggunakan kata Sulthan karena Rasulullah menginginkan makna penguasa itu kepada penguasa muslim. Sudah dimaklumi di dunia Islam bahwa kata sulthan itu bersinonim dengan raja. Raja bersinonim dengan sulthan, kepala negara dan malik. Di Indonesia kata Sulthan lebih banyak 言

${ }^{8}$ A. Djazuli, Fiqih Siyâsah Implementasi Kemaslahatan Umat dalam Rambu-rambu Syariah, hal . 59.

${ }^{9}$ Al-Bukhari, Shahih al-Bukhâri (No. 956)

${ }^{10}$ Prof. DR. Mahmud Yunus, Kamus Mahmud Yunus, Penerbit Mahmud Yunus wa Dzurriyyah, Jakarta Tahun 2013M , hal. 428. 
dikenal daripada Khalifah, Imam, Malik atau Amir. Kata Sulthan diserap dalam bahasa Indonesia dengan konsep makna yang sama yaitu Raja/Kepala Pemerintahan Muslim. ${ }^{11}$

Ungkapan kata sulthan dengan makna berkuasa bisa kita baca dalam firman Allah berikut:

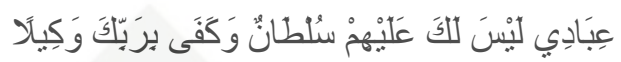

Sesungguhnya hamba-hamba-Ku, kamu tidak dapat berkuasa atas mereka. Dan cukuplah Tuhan-mu sebagai Penjaga. (QS. Al-Isra' ayat :65) ${ }^{12}$

Di Indonesia seorang pemimpin atau kepala negara dipegang oleh seorang presiden. Menurut Undang-Undang Dasar Negara Republik Indonesia Tahun 1945 (UUD 45) Pasal 4 Presiden adalah pemegang kekuasaan pemerintahan yang dalam melakukan kewajibannya sebagai Presiden dibantu oleh seorang Wakil Presiden. ${ }^{13}$

Istilah kepemimpinan, dalam kamus bahasa Indonesia berasal dari kata "pimpin” yang mempunyai arti "dibimbing". Sedangkan kata pemimpin itu sendiri mempunyai makna "orang yang memimpin." Jadi kepemimpinan adalah (2) cara untuk memimpin ${ }^{14}$

Keimamahan negara yang berasal dari imam ini dibagi menjadi 4 (empat) bagian yaitu :

${ }^{11}$ A. Djazuli, Fiqih Siyâsah Implementasi Kemaslahatan Umat dalam Rambu-rambu Syariah, hal. 60.

ב. $\quad{ }^{12}$ Departemen Agama RI, Al-Qur'an dan Terjamahannya

${ }^{13}$ Undang-Undang Dasar Negara Republik Indonesia Tahun 1945 Pasal 4

${ }^{14}$ Departememen Pendidikan dan Kebudayaan, Kamus Besar Bahasa Indonesia, (Jakarta: Balai Pustaka, 1994), cet. ke-4, h. 967. 
1. Kepemimpinan yang mempunyai kekuasaan secara umum dan bekerja pada bidang umum. Mereka dimaknai dengan sebutan menteri, mereka menerima kekuasaan untuk mengerjakan tugas-tugas yang tidak ditentukan bentuknya.

2. Yang mempunyai kekuasaan umum dan bekerja di daerah-daerah khusus, mereka dinamai dengan nama sebutan gubernur daerah, mereka ini berwenang dalam semua urusan yang ada di daerahnya yang menjadi tanggung-jawabnya.

3. Yang mempunyai kekuasaan khusus dan bekerja pada bidang regional yang umum seperti Qadhi, komandan militer, kejaksaan, pengatur perpajakan, pembagi sedekah.

4. Yang mempunyai kekuasaan khusus dan bekerja pada bidang khusus seperti Qadhi daerah, komandan militer daerah, kejaksaan daerah, pengatur perpajakan daerah, pembagi sedekah daerah. ${ }^{15}$

Sedangkan secara umum, kepemimpinan adalah kemampuan dan kesiapan seseorang untuk dapat mempengaruhi, mendorong, mengajak, menuntun, Sedangkan secara umum, kepemimpinan adalah kemampuan dan kesiapan $\exists$. seseorang untuk dapat mempengaruhi, mendorong, mengajak, menuntun, menggerakkan, dan kalau perlu memaksa orang lain agar ia ia menerima pengaruh itu, selanjutnya berbuat sesuatu yang bisa mencapai suatu maksud atau tujuan tertentu. ${ }^{16}$

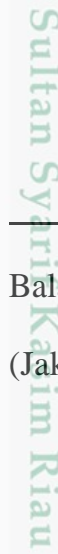
${ }^{15}$ Departememen Pendidikan dan Kebudayaan, Kamus Besar Bahasa Indonesia, (Jakarta:
Balai Pustaka, 1994), cet. ke-4, h. 209-210

${ }^{16}$ Hendiyat Soetopo dan Waty Soemanto, Kepemimpinan dan Supervisi Pendidikan, (Jakarta: Bina Aksara, 1984), hlm. 1 
Dalam istilah lain pemimpin itu sering merujuk pengertian Ulil Amri atau pejabat adalah orang yang mendapat amanah untuk mengurus urusan orang lain dan Khadimul Umat ( pelayan umat ) dengan pengertian seorang pemimpin harus menempatkan dirinya itu pada posisi sebagai pelayan masyarakat. ${ }^{17}$

Menurut Riyas Rasyid kepemimpinan adalah sebuah konsep yang merangkum berbagai segi dari interaksi pengaruh pemimpin dengan pengikutnya dalam mengejar tujuan bersama. ${ }^{18}$

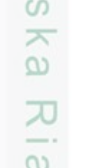

Munurut Muhammad Rasyid Ridho rahimahullahu berkata dalam bukunya at-Khilafah beliau mendefinisikan tentang pemimpin (al-Khilafah), ia berkata:

al-khilafah, al-imamah al-'uzma, imaratul mukminin adalah tiga kata yang maknanya adalah satu yaitu pemerintahan secara Islam yang mengemban tugas secara keseluruhan demi meraih kemaslahatan agama dan dunia. ${ }^{19}$

Dari beberapa pengertian yang telah dikemukakan di atas terdapat butirbutir pengertian pada hakikatnya memberikan makna antara lain :

1. Kepemimpinan adalah suatu yang melekat pada diri seseorang pemimpin yang berupa sifat-sifat tertentu seperti kepribadian (personality), kemampuan (ability), kesanggupan (capability).

2. Kepemimpinan adalah serangkaian kegiatan (activity) pemimpin yang tidak dapat dipisahkan dengan kedudukan posisi serta gaya atau prilaku pemimpin itu sendiri.

${ }^{17}$ K.H. Didin Hafidhuddin dan Hendri Tanjung S.Si, MM, Manajemen Syari'ah dalam Praktik, Cet. I, Jakarta; Gema Insani Perss, 2003, hal, 120

=. ${ }_{18}$ Muhammad Ryass Rasyid, Makna Pemerintahan; Tinjauan dari Segi Etika dan Kepemimpinan, PT. Mutiara Sumber Wijaya. 2000 Cet. I, h., 95

${ }^{19}$ Muhammad Rasyid Ridho, Al-Khilâfah, Penerbit al-Zahrâ li al-'alâm al-'araby Kairo Mesir, Hal.17 
3. Kepemimpinan adalah suatu proses antar hubungan atau interaksi antara bawahan dan situasi ${ }^{20}$

Dari beberapa defenisi kepemimpinan tersebut, dapat disimpulkan bahwa kepemimpinan adalah suatu kegiatan mempengaruhi orang lain agar orang tersebut mau bekerja sama (mengolaborasi dan mengelaborasi potensinya) untuk mencapai tujuan yang telah ditetapkan. Kepemimpinan juga sering dikenal sébagai kemampuan untuk konsensus anggota organisasi untuk melakukan tugas o manajemen agar tujuan organisasi tercapai. ${ }^{21}$

\section{2) Urgensi Seorang Pemimpin dalam Islam}

Mengangkat seorang pemimpin dalam Islam adalah permasalahan yang sangat urgen, maka dalam hal ini di kalangan tokoh dan intelektual muslim mereka memiliki variasi pendapat. Menurut semua ulama Sunni, Syi'ah dan Murji'ah, mayoritas pengikut Mu'tazilah dan Khawarij, kecuali sakte Najdat, mengangkat pemimpin itu wajib hukumnya. Karena itu, akan berdosa bila meninggalkannya. ${ }^{22}$

Sedangkan menurut golongan najdat salah satu sakte Khawarij, utamanya Fathiyah Ibn Amir al-Hanafi, mengangkat pemimpin itu hukumnya mubah. B Artinya, terserah pada kehendak umat atau rakyat mau melakukannya atau tidak. Umat atau rakyat tidak berdosa apabila meninggalkannya, dan tidak pula

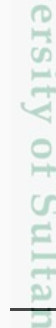

(5) Wahjosumidjo, Kepemimpinan dan Motivasi, Jakarta; Ghalia Indonesia, 1987. Cet. III, ha1. 25

${ }^{21}$ Baharuddin \& Umiarso, Kepemimpinan Pendidikan Islam, Penerbit : Ar-Ruzz Media, Tahun Terbit : 2017, hlm. 50

${ }^{22}$ Mujar Ibnu Syarif, Khamami Zada, Fiqh Siyasah Doktrin dan Pemikiran Politik Islam, (Jakarta: Erlangga, 2008), hal. 108 
mendapat pahala bila melakukannya. Sebab tidak ada satu pun argumentasi naqliyah dan aqliyah yang memerintahkan atau melarangnya. ${ }^{23}$

Pandangan senada dengan kaum Najdat antara lain didukung pula oleh sebagian kecil pengikut Mu’tazilah, utamanya Abu Bakar al-Asham, Hisyam Ibn Amr al-Futi dan Ubad Ibn Sulaiman, salah seorang murid Hisyam Ibn Amr alFuti. Bahkan lebih jauh dari itu al-Asham, sebagaimana disinggung sebelumnya, berpendapat bahwa mengangkat pemimpin itu tidak perlu sama sekali bila umat co manusia telah tunduk dan patuh pada peraturan dan setia pada kebenaran. Tapi bila sebaliknya, yakni melanggar peraturan dan menyimpang dari garis kebenaran yang berdampak pada timbulnya anarki, maka barulah boleh diangkat seorang pemimpin untuk meluruskannya. ${ }^{24}$

Al-Qurtubhi seorang ulama sunni terdepan, ia memberi tanggapan terhadap pernyataan al-Asham dan ia mengatakan bahwa al-Asham adalah orang yang tidak mengerti syariat (Islam), begitu juga orang-orang yang berkata seperti perkataannya dan juga orang-orang yang mengikuti pendapat madzhabnya. Menurut Al-Qurthubi mengangkat seorang pemimpin merupakan perintah yang harus didengar dan ditaati, agar persatuan dapat terwujud karenanya dan hukum贾 hûkumnya dapat terlaksana. ${ }^{25}$

Al-Qurthubi juga menjadi argumentasinya dalam hal ini adalah perbuatan para sahabat Rasulullah shallallahu 'alaihi wasallam. Mereka sepakat untuk mengangkat Abu Bakar Shiddiq radhiyallahu 'anhu setelah terjadi perselisihan Qu

${ }^{23}$ Ibid.

${ }^{24}$ Mujar Ibnu Syarif, Khamami Zada, Fiqh Siyasah Doktrin dan Pemikiran Politik Islam, Hal.108-109.

- ${ }^{25}$ Al-Qurthubi, Tafsir al-Qurthubi, (264 /1) yang dikenal dengan al-Jâmi' li Ahkâm alQur'ân, oleh Abu 'Abdullah Muhammad bin Ahmad bin Abu Bakr Al-Anshari alQurthubi, Cetakan Daru al-'âlam al-kutub, Riyadh, KSA, Tahun 1423H/2003M. 
antara kaum Muhajirin dan kaum Anshar di Saqifah Bani Sa'idah tentang penentuan siapa yang akan menjadi khalifah pengganti Rasulullah shallallahu 'alaihi wasallam. Ketika itu kaum Anshar berkata : "Dari kami seorang amir dan dari kalian seorang amir." 26

Keinginan kalangan Anshar ini ditolak oleh Abu Bakar, Umar dan kalangan Muhajirin. Kalangan Muhajirin berkata, "Sesungguhnya bangsa Arab Z tidak akan beragama kecuali karena sekelompok orang dari kaum Quraisy ini”. c

Mereka juga menceritakan kepada kalangan Anshar tentang keberhakan orang Quraisy sebagai pemimpin. Akhirnya kalangan Anshar menerima dan taat kepada kaum Quraisy dari kalangan Muhajirin tersebut. Seandainya pengangkatan pemimpin itu tidak wajib, tidak pada kaum Quraisy dan tidak pula pada selain mereka, tentu tidak akan ada artinya dialog dan perdebatan tersebut. Tentu saat itu ada di antara mereka yang berkata, "pengangkatan imam itu tidak wajib, tidak pada orang Quraisy dan tidak pula pada selain mereka. Perdebatan kalian ini tidak berguna, sebab ini adalah perdebatan mengenai perkara yang tidak wajib.” 27

Kaum sunni sepakat bahwa mengangkat seorang pemimpin itu hukumnya adalah wajib. Kewajiban tersebut, menurut al-Rayis bukan kewajiban individual 3

(wajib aini), tetapi kewajiban kolektif (wajib kifa'i/fardu kifayah). Karena itu, seluruh umat Islam berdosa bila tidak melakukannya, namun bila ada yang mewakilinya, umat Islam yang lain terlepas dari dosa akibat meninggalkannya. Pendapat senada dengan ini juga dianut pula oleh al-Mawardi dan al-Ghazali. ${ }^{28}$

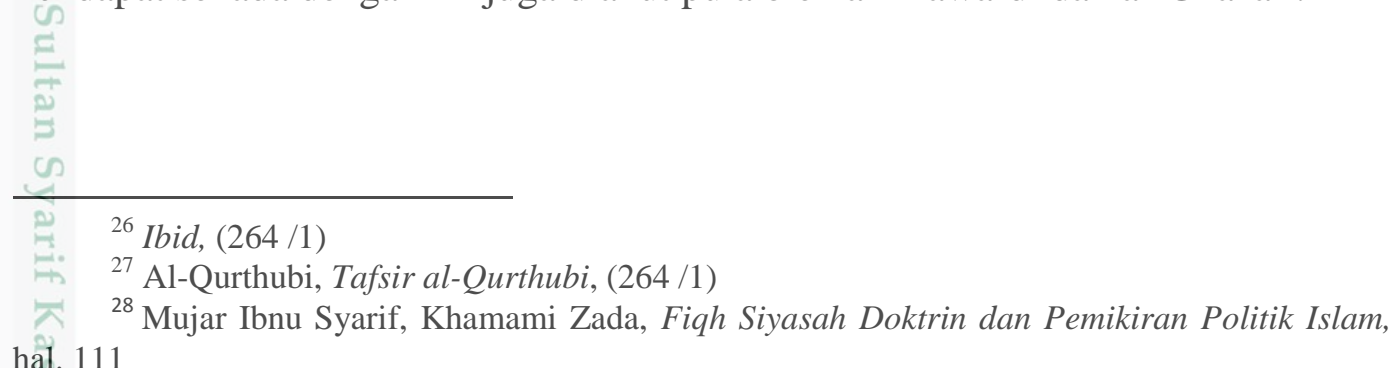
hal. 111 
Menurut Ibnu Taimiyyah rahimahullah bahwa kepemimpinan itu sebagai bagian dari agama dan sarana bertaqarrub kepada Allah. Bertaqarrub kepada-Nya dalam kepemimpinan itu, maksudnya adalah dengan mentaati Allah dan mentaati Rasul-Nya, dan ini termasuk ke dalam taqarrub yang paling utama. Bahkan agama (Islam) ini tidak akan dapat tegak kecuali dengan kepemimpinan. Sedangkan seluruh anak adam (manusia) mustahil akan mencapai kemaslahatan optimal jika z tidak ada kontrak sosial, mengingat sifat manusia itu adalah saling membutuhkan co

di antara mereka. Suatu kontrak sosial ini sudah pasti membutuhkan seorang pemimpin untuk mengendalikan. ${ }^{29}$

Kaum Syiah pun mempunyai pandangan yang sama dengan kaum Sunni, yakni mengangkat pemimpin itu merupakan kewajiban berdasarkan syariat. Hanya saja, dalam hal ini kaum Syi'ah memiliki pendapat yang sangat berbeda dengan kaum Sunni, yakni wajib mengangkatnya adalah Allah bukan umat atau rakyat. Argumentasinya, masalah pengangkatan imam itu bukanlah masalah ijtihadiah yang dapat diserahkan kepada kreatifitas akal manusia. Akan tetapi, ia merupakan rukun agama. Karena itu, hanya Allah dan Rasul-Nya saja yang dapat menunjuk imam, bukan rakyat. Imam adalah wakil Allah dan Rasul-Nya. Tidak 多. ada yang boleh menunjuknya, kecuali Allah dan Rasul-Nya. ${ }^{30}$

Sedangkan kaum Mu'tazilah pada umumnya mereka berpendapat bahwa pengangkatan pemimpin itu merupakan kebutuhan manusia yang cenderung hidup bermasyarakat. Sebagai makhluk sosial tidak mungkin manusia hidup tanpa berhubungan dengan manusia lainnya. Dalam pergaulan itu amat dimungkinkan

${ }^{29}$ Ibnu Taimiyyah, Al-Siyasah al-Syariyah Etika Politik Islam, Terjemahan oleh Rofi' Munawwar, dari kitab al-siyâsah al-syar'iyyah fî islâhi al-râ'iy wa al-râ'iyyah, (Surabaya: Risalah Gusti, 2005), hal. 227

Mujar Ibnu Syarif, Khamami Zada, Fiqh Siyasah Doktrin dan Pemikiran Politik Islam, hal. 111 
terjadinya perselisihan, pertikaian, konflik, penindasan, pertumpahan darah, atau pembunuhan. Bahkan, dapat pula menyulut dan mengobarkan api peperangan yang akan menelan banyak korban, baik materi ataupun yang lainnya yang akan mèrusak segala sendi kehidupan. Pada saat seperti itulah, naluri manusia mendambakan tampilnya orang-orang tertentu yang akan menjadi juru selamat. Artinya, secara akli dapat dipastikan kemestian adanya seorang pemimpin. Karena Z

itu, kendatipun wahyu tidak turun menyangkut eksistensi seorang pemimpin, maka berdasarkan rasio manusia sudah pasti dapat menentukan sikapnya sendiri bertalian dengan eksistensi seorang pemimpin itu. ${ }^{31}$

\section{3) Dasar Hukum Kepemimpinan Dalam Islam}

Dasar-dasar masalah kepemimpinan dalam Islam secara umum tentulah sangat banyak disinggung dalam nash-nash al-Qur'an maupun teks-teks al-Hadits, diantaranya sebagaimana berikut ini:

Firman Allah Subhânahu wa-Ta'âlâ

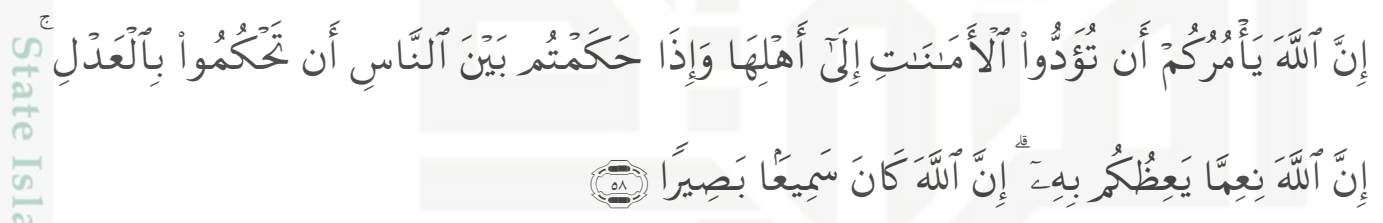

“Sesungguhnya Allah menyuruh kamu menyampaikan amanat kepada yang berhak menerimanya, dan (menyuruh kamu) apabila menetapkan hukum di antara manusia supaya kamu menetapkan dengan adil. Sesungguhnya Allah memberi pengajaran yang sebaik-baiknya kepadamu. Sesungguhnya Allah ¡adalah Maha mendengar lagi Maha Melihat”. (QS. Al-Nisa/4 : 58)

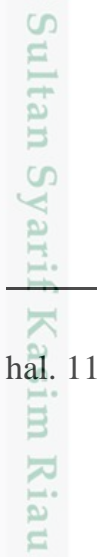

${ }^{31}$ Mujar Ibnu Syarif, Khamami Zada, Fiqh Siyasah Doktrin dan Pemikiran Politik Islam, hal. 113 


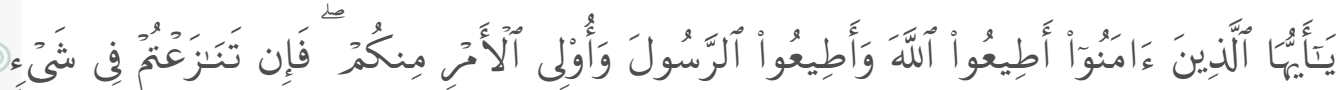

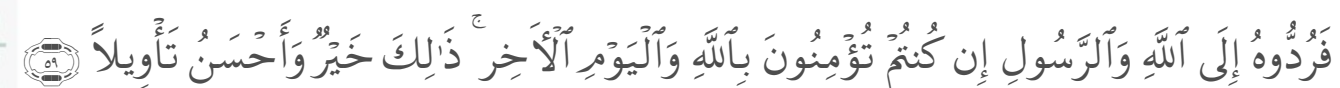
"Hai orang-orang yang beriman, taatilah Allah dan taatilah Rasul-Nya, dan Ulil Amri di antara kamu. Kemudian jika kamu berlainan pendapat tentang - sesuatu perkara, Maka kembalikanlah permasalahan tersebut kepada Allah (Al Quran) dan Rasul (Sunnahnya), jika kamu benar-benar beriman kepada Allah dan hari kemudian. yang demikian itu lebih utama (bagimu) dan lebih baik akibatnya" (QS. Al-Nisa/4 : 59) ${ }^{32}$

不

Ibnu Katsir seorang pakar tafsir bermazhab syafi'i menyimpulkan dari dua ayat diatas adalah sebagai berikut, pada ayat 58 adalah berisi perintah Allah kepada kepada siapa saja (termasuk pemimpin) agar mereka menunaikan amanah yang ada pada pundak mereka kepada mereka yang berhak mendapatkannya dan kepada pemimpin hendaklah ia berlaku adil dalam memutuskan perkara-perkara yang terjadi pada rakyatnya ${ }^{33}$, dan kemudian pada ayat yang ke 59 adalah berisi perintah Allah kepada rakyat, agar mereka mentaati Allah dan Rasul-Nya shalallâhu 'alaihi wa-sallam dengan menjalani perintah-perintah Allah dan Rasul(-

Nya dan menjauhi larangan-larangan keduanya, kemudian perintah Allah kepada rakyat agar mereka mentaati pemimpin mereka yang mentaati Allah dan RasulNya shalallâhu 'alaihi wa-sallam, dan mereka tidak boleh ta'at kepada pemimpin mereka dalam bentuk kemaksiatan ${ }^{34}$

Kemudian perhatikan juga firman Allah Subhânahu wa-Ta'âlâ dalam surat Shaad ayat 26 yang berbunyi:

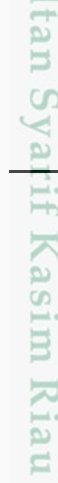

\footnotetext{
${ }^{32}$ Departemen Agama RI, Al-Qur'an dan Terjamahannya

${ }^{33}$ Ibnu Katsir, Tafsir Ibnu Katsir (1/709)

${ }^{34}$ Ibid, (1/712)
} 


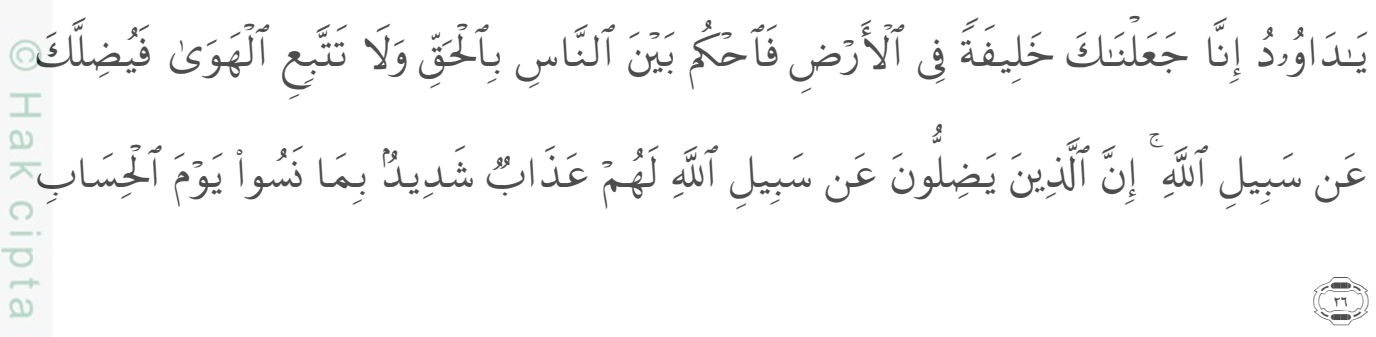

“Hai Daud, sesungguhnya Kami menjadikan kamu khalifah (penguasa) di -muka bumi, maka berilah keputusan (perkara) di antara manusia dengan adil dan janganlah kamu mengikuti hawa nafsu, karena ia akan menyesatkan kamu $\subset$ dari jalan Allah. Sesungguhnya orang-orang yang sesat dari jalan Allah akan mendapat azab yang berat, karena mereka melupakan hari perhitungan” (QS Shaad/38, ayat 26) ${ }^{35}$

Ayat ini merupakan wasiat Allah kepada para pemimpin yang memegang kekuasaan agar mereka berlaku adil kepada manusia dalam menjalankan roda pemerintahannya dengan berpedomankan kepada ajaran-ajaran yang diturunkan oleh Allah dan jangan sekali-kali berpaling dari syari'at Allah, kalau kalian berpaling dari syari'at-Nya maka pasti Dia (Allah) akan menyesatkan kalian dari jalan-Nya, orang-orang (yaitu para pemimpin) yang menyimpang dari jalan-Nya maka Allah menjanjikan untuk mereka hisab yang berat dan azab yang pedih di hari kiamat kelak.

Berkenanan dengan ayat ini, (seorang Amirul Mukminin) bernama AlWälid Bin Abdul Malik berkata kepada Abu Zur’ah: “Apakah seorang khalifah akan dihisab pada hari kiamat kelak" ? Maka Abu Zur'ah menjawab: "Wahai Amirul Mukminin, apakah anda lebih mulia daripada Nabi Daud 'alaihi salâm...?, sedangkan Nabi Daud itu, Allah kumpulkan pada dirinya kemuliaan sebagai seorang Nabi dan ia juga seorang khalifah, maka tetap Allah menjanjikan

${ }^{35}$ Departemen Agama RI, Al-Qur'an dan Terjamahannya 
kepadanya untuk hisab yang berat dan azab yang pedih (apabila dia tidak menjalankan syari' at Allah dalam kepemimpinannya). ${ }^{36}$

Nabi kita Muhammad shalallâhu 'alaihi wa-sallam, beliau senantiasa mengingatkan ummatnya agar mereka benar-benar memperhatikan masalah yang sangat urgent ini, sebagaimana dalam riwayat-riwayat berikut ini

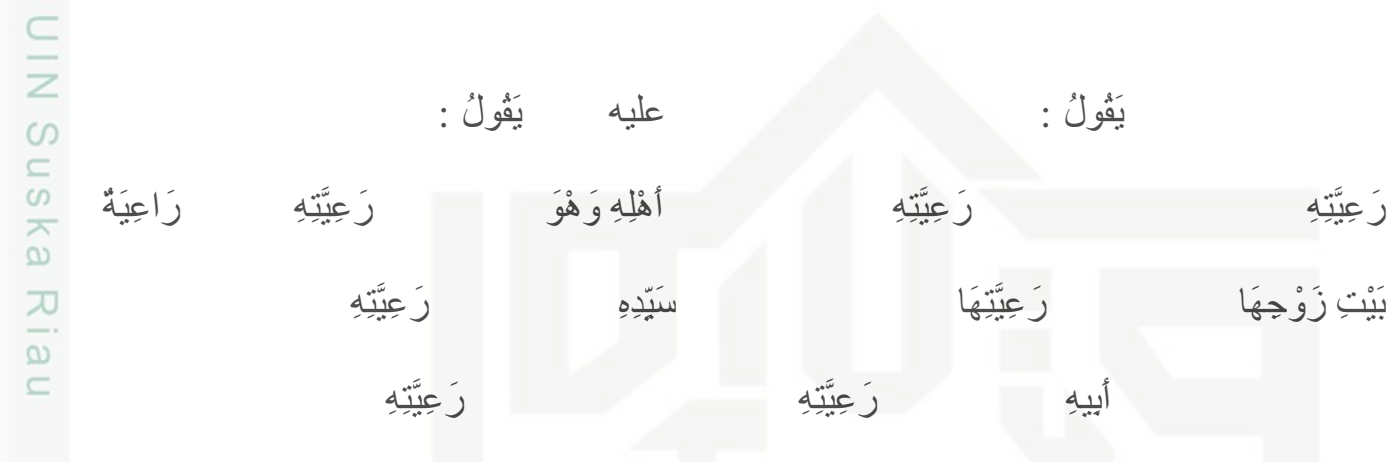

Dari Ibn umar radhiyallahu 'anhuma dari Nabi shalallâhu 'alaihi wasallam sesungguhnya bersabda : Sesungguhnya Rasulullah shalallâhu 'alaihi wasallam bersabda : "Setiap kalian adalah pemimpin dan kalian akan diminta tanggung jawaban atas kepemimpinannnya. Seorang kepala negara adalah pemimpin atas rakyatnya dan dia akan diminta tanggung jawabannya perihal rakyat yang dipimpinnya. Seorang suami pemimpin atas anggota keluarganya dan akan ditanya perihal keluarga yang dipimpinnya. Seorang isteri pemimpin - atas rumah tangga dan anak-anaknya dan akan ditanya perihal tanggung jawabnya. Seorang pembantu rumah tangga ia bertugas memelihara barang milik majikannya dan akan ditanya atas tanggung jawabannya. Dan kamu sekalian pemimpin dan akan ditanya (diminta pertanggungan jawab) darihal hal yang dipimpinnya" (HR. Al-Bukhari) ${ }^{37}$.

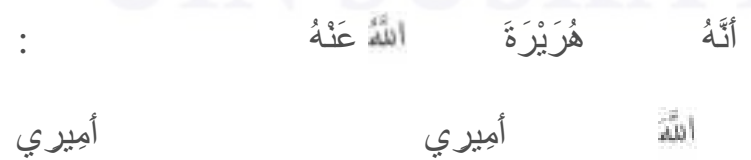

${ }^{36}$ Ibnu Katsir, Tafsir Ibnu Katsir, (4/2430)

${ }^{37}$ Al-Bukhari, Shahihu al-Bukhari, (No.7137) 
Abu Salamah bin Abdur al Rahman berkata bahwa sesungguhnya saya telah Imendengar Abu Hurairah berkata: Sesungguhnya Rasulullah shalallâhu 'alaihi wa-sallam beliau berkata: "Barangsiapa yang mentaatiku maka dia -telah mentaati Allah, barangsiapa yang bermaksiat kepadaku maka dia juga berbuat maksiat Allah dan barangsiapa yang berbuat maksiat kepada - pemimpin kalian (yang aku angkat untuk kalian) maka berarti dia bermaksiat kepadaku. (HR. Al-Bukhari) 38

Nabi shalallahu 'alaihi wa-sallam sangat sering mengingatkan kita sebagai ummatnya agar memperhatikan masalah yang sangat urgent ini, diantara sekian banyak hadits-hadits yang menjelaskan hal penting ini adalah hadits berikut:

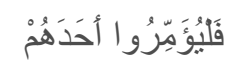

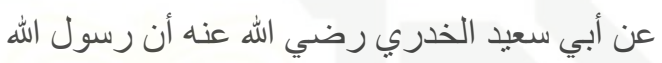

Dari Abu Sa'id Al-Khudri Radhiyallahu 'Anhu, Bahwa Rasulullah shalallahu 'alaihi wa-sallam beliau berkata: "Apabila ada tiga orang bepergian, hendaknya mereka mengangkat salah seorang di antara mereka sebagai pemimpinnya”.(HR. Abu Dawud) ${ }^{39}$

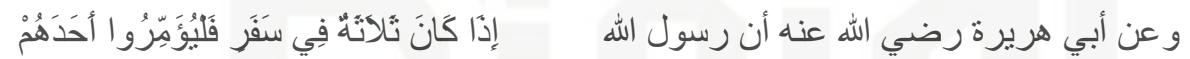

Abu Hurairah radhiyallâhu 'anhu, bahwa Rasulullah shalallâhu 'alaihi wasallam berkata: "Jika tiga orang bepergian, maka hendaklah mereka "mengangkat seseorang diantara mereka sebagai pemimpin” (HR. Abu Dawud) ${ }^{40}$

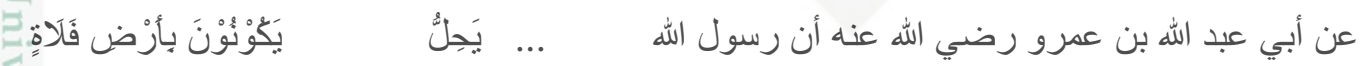

Dari Abu Abdullah bin Amar radhiyallâhu 'anhu, Bahwa Rasulullah shalallâhu 'alaihi wa-sallam berkata: "Tidak dihalalkan (dibolehkan) bagi

${ }^{39}$ Abu Dawud, Sunan Abi Daud, (No. 2608)

40 Ibid, No. 2609 
tiga orang yang berada di suatu tempat, kecuali mereka mengangkat salah ¿seorang dari mereka sebagai pemimpin mereka”.(HR. Ahmad) ${ }^{41}$

Maka berdasarkan ayat-ayat dan hadits-hadits diatas, Allah dan RasulNya telah memberikan gambaran secara terang dan jelas bahwa syari'at Islam itu sangat memandang penting persoalan seorang pemimpin dalam bermasyarakat, berbangsa dan bernegara. Dan dalam permasalahan ini juga Nabi shalallâhu 'alaihi wa-sallam telah memberikan intruksi kepada ummat Islam agar mereka memperhatikan permasalahan kepemimpinan ini walaupun hanya dalam sebuah kelompok kecil masyarakat, maka mesti ada seorang pemimpinnya apalagi dalam jumlah kelompok masyarakat yang banyak.

\section{4) Syarat-Syarat Seorang Pemimpin Dalam Perspektif Islam}

Memerankan seorang pemimpin merupakan tugas yang sangat mulia dan memiliki kedudukan yang sangat tinggi dalam Islam. Diantara kewajiaban yang paling pokok seorang pemimpin itu adalah menegakkan agama Islam dan mensejahterahkan kehidupan dunia ummat Islam, bahkan telah dinukilkan oleh Ibnu Taimiyyah sebuah perkatan:

\section{لبلة}

"Enam puluh tahun bersama pemimpin yang dzalim lebih baik daripada sehari semalam tanpa adanya pemimpin". ${ }^{42}$

Para ulama telah menyebutkan syarat-syarat imamah (kepemimpinan) dalam Islam sebagaimana berikut ${ }^{43}$ :

1. Taklif: Ini meliputi Islam, baligh, dan berakal.

\footnotetext{
${ }^{41}$ Ahmad bin Hambal, Musnad Imam Ahmad (No. 6609)

${ }^{42}$ Ibnu Taimiyyah, al-siyâsah al-syar'iyyah fî islâhi al-râ'iy wa al-ra'iyyah, Hal. 217

${ }^{43}$ Dr. Khalid bin Ali al-'Anbari, Fiqhu al-Siyâsah al-Syar'iyyah hlm. 125-134
} 
Maka orang kafir (non Muslim) tidak boleh dipilih menjadi pemimpin, berdasarkan firman Allah Subhanahu wa Ta'ala:
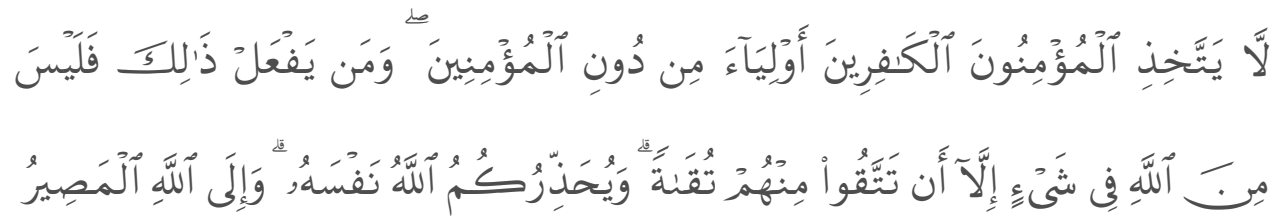

Janganlah orang-orang mukmin mengambil orang-orang kafir menjadi "wali" ${ }^{44}$ dengan meninggalkan orang-orang mukmin. Barang siapa yang berbuat demikian itu, niscaya lepaslah ia dari pertolongan Allah, kecuali Karena (siasat) memelihara diri dari sesuatu yang ditakuti dari mereka. dan Allah memperingatkan kamu terhadap diri (siksa)-Nya. dan Hanya kepada Allah kembali (mu). (QS. Âli 'Imrân/3: 28) ${ }^{45}$

Demikian juga orang yang tidak berakal, baik karena masih kecil atau karena dia kehilangan akalnya, maka orang seperti ini sama sekali dia tidak boleh memegang kepemimpinan dan kekuasaan atau yang semisalnya.

2. Lelaki. Wilayah kubra (kepemimpinan tertinggi) tidak boleh bagi seorang perempuan dengan kesepakatan para ulama. ${ }^{46}$

Dalilnya adalah hadits dari Abu Bakrah radhiallâhu 'anhu beliau berkata, “Tatkala sampai berita kepada Rasulullah shallallâhu 'alaihi wa Sallam, bahwa penduduk Persia dipimpin oleh seorang wanita yaitu putri dari raja Kisra (gelar raja Persia), maka beliau bersabda:

${ }^{44}$ Wali itu adalah kata tunggal dan jamaknya adalah Auliyâ': berarti teman akrab atau teman setia/dekat, juga berarti pemimpin, pelindung atau penolong

${ }^{45}$ Departemen Agama RI, Al-Qur'an dan Terjamahannya

${ }^{46}$ Wahbah Az-Zuhaili Al-Fiqh al-Islami wa adillatuhu, (6/745) oleh Prof. Dr. Wahbah AzZuhaili, Penerbit Dâru al-fikri, Cetakan XII tanpa tahun terbitan, Damaskus-Lebanon 
"Suatu kaum tidak akan beruntung jika dipimpin oleh seorang wanita." (HR. Al-Bukhari) ${ }^{47}$

Dan ini sama sekali bukan pelecehan kepada wanita tetapi justru untuk menghormati kaum wanita yang memiliki tugas penting di istana keluarganya. ${ }^{48}$

3. Al-'Adalah. Yaitu sifat yang membuat pribadinya bertaqwa, dia menjauhi dosa-dosa, dan hal-hal yang merusak harga dirinya di tengah-tengah ummat Islam.

4. Ilmu dan tsaqafah. Seorang pemimpin itu disyaratkan dia adalah orang yang mempunyai kafasitas ilmu syar'i dan tsaqafah mumpuni, agar dia bisa mengetahui antara yang haq dari yang bathil dan dia bisa mengatur urusan-urusan negara dengan penuh kemaslahatan bagi rakyat serta dia juga bisa mengetahui strategi perang menghadapi musuh, dan ilmu yang paling utama yang harus dimiliki oleh seorang pemimpin itu adalah ilmu tentang hukum-hukum Islam dan siyâsah syar'iyyah (politik syar'i).

Rakyat tidak butuh kepada pemimpin yang rajin sholatnya atau rajin menelaah kitab-kitab ulama, aktif mengajar atau menulis buku, berhatihati dari pembunuhan, padahal kondisi negerinya tengah dilanda kekacauan, yang kuat menginjak yang lemah, yang punya kekuasaan berbuat semena-mena terhadap rakyat lemah, karena jika demikian maka tidak ada artinya seorang pemimpin karena tidak memiliki peran penting dalam mengatasi masalah negara.

${ }^{47}$ Al-Bukhari, Shahih al-Bukhari (No. 4425)

${ }^{48}$ Dr. Muhammad Uqlah, Nidzômu al-Usroh fì al-Islam, (2/48) Penerbit Maktabah alRisalah al-Haditsah, Aman-Urdun Cetakan Tahun 1423H/2002 
5. Mengerti Tentang Politik Syar'i secara Matang. Seorang pemimpin itu harus mengerti ilmu tentang politik syar'i untuk pengaturan negara dan kebaikan rakyatnya, dia juga berpengalaman tentang urusan perang dan mengatur prajurit, membela negara dan perbatasan dan dia wajib membela rakyat yang terdzalimi. ${ }^{49}$

6. Seorang Quraisy. Berdasarkan sabda Rasulullah Shallallahu 'Alaihi wa Sallam: "Para pemimpin adalah dari Quraisy." 50

Hanya saja, persyaratan ini khusus bagi imamah 'uzhma ketika kaum muslimin seluruhnya dipimpin oleh seorang khalifah. Al-Imam alQurthubi Rahimahullahu Ta'ala berkata, "Karena umat telah sepakat bahwa seluruh kepemimpinan-kepemimpinan sah bagi selain Quraisy kecuali imamah kubra." 51

7. Sehat panca indranya. Tidak boleh pemimpin itu sorang yang tuli, buta atau bisu, karena hal itu sangaat berpengaruh dalam kinerjanya menjalankan tugas sebagai pemimpin negara, adapun cacat lainnya yang tidak mempengaruhi maka tidak apa-apa. ${ }^{52}$

${ }^{49}$ Al-Qurthubi, Jamî'u al-Ahkâm al-Fiqihiyyah li al-Imam al-Qurthubi min tafsîrihi, dihimpun dan disusun oleh Farîd Abdu al-Aziz al-Jundiy (3/415), Penerbit Dâru al-kutub al'ilmiyyah Bairut Libanon Cet. II, Tahun 1426H / 2005M

${ }_{50}^{5}$ Ahmad bin Hanbal, Musnad Ahmad bin Hanbal (3/129)

${ }^{51}$ Al-Qurthubi, Al-Mufhim limâ asykala min kitab talkhish muslim, oleh Abu 'Abdullah Muhammad bin Ahmad bin Abu Bakr Al-Anshari al-Qurthubi, (4/6) Penerbit Dâru Ibni Katsir, Tahun 1417 H / 1996M

${ }^{52}$ Imam al-Mawardi, Al-Ahkâm al-Shulthôniyyah oleh Abu al-Hasan Ali Ibn Muhammad Ibn Habib al-Mawardi (972 - 448H/1058), Penerbit Daru al-Hadits Kairo Mesir, Tanpa Tahun Terbitan, hlm 6. 
Menurut Imam Abu Al-Hasan Ali Bin Muhammad Al-Mawardi di dalam kitabnya Al-Ahkam As-Sulthoniyyah menyebutkan ${ }^{53}$ bahwa :

"Kepemimpinan politik dalam Islam itu bertujuan untuk meneruskan misi kenabian dalam menegakkan agama dan juga mengatur urusan dunia. Untuk itu, orang yang akan memangku amanah ini harus memiliki syarat-syarat antara lain:

(1) Adil (dengan berbagai syaratnya, termasuk di dalamnya adalah seseorang itu mesti beragama Islam),

(2) Memiliki ilmu yang dapat mengantarkannya untuk melakukan ijtihad,

(3) Sehat panca indra,

(4) Sehat anggota tubuh,

(5) Memiliki kecerdasan, dan

(6) Memiliki keberanian untuk menerapkan berbagai aturan”.

Dari keenam syarat yang telah ditetapkan Imam Al-Mawardi ini esensinya hanya dua seperti yang disebut Syekhul Islam Ibnu Taimiyyah, yaitu: memiliki kekuatan (al-quwwah) dan amanah (al-amin). Maka "Islam" pasti merupakan salah satu syarat mutlak di dalamnya karena tujuan dari kepemimpinan itu sendiri adalah untuk menegakkan agama sebagaimana tugas para Nabi.

$\stackrel{\infty}{\infty}$ Syekh Muhammad Rasyid Ridho Rahimahullahu berkata dalam bukunya At-Khilafah ${ }^{54}$ :

"Syarat yang diakui dalam Islam pada diri seorang Khalifah (pemimpin), Sebagaimana ungkapan As-Sa'ad: telah disebutkan dalam kitab-kitab figh kami, bahwa sesungguhnya ummat (Islam) mesti memiliki seorang pemimpin yang bertugas untuk menegakan Agama Islam, menghidupkan As-Sunnah, menolong orang-orang terzalimi, menegakkan hak-hak dan meletakkan hak-hak tersebut $=$ pada tempat-tempatnya, maka seorang pemimpin disyaratkan :

(1) Sorang Yang Mukallaf (Sudah Dewasa),

${ }^{53}$ Ibid. Hal. 3-5

${ }^{54}$ Muhammad Rasyid Ridho, Al-Khilafah, Hal. 25-26 
(2) Seorang Muslim

工(3) Seorang Yang Berlaku Adil

(4) Seorang Yang Merdeka

(5) Seorang Laki-laki

(6) Sorang Mujtahid

(7) Seorang Pemberani

(8) Seorang Yang Memiliki Yang Cukup

(9) Seorang Yang Mendengar

(10) Seorang Yang Melihat

굿 (11) Seorang Yang Pandai Bicara (Tutur Katanya Jelas)

()

(12) Seorang Yang Berasal dari Quraisy, jika tidak dari Quraisy maka dari suku Kinanah, jika tidak ada suku Kinanah, maka dari keturunan nabi Isma'il, dan jika tidak ada juga maka dari 'Ajam (non Arab).

Syekh Shalah Al-Shawi di dalam kitabnya Al-Wajîz. ${ }^{55}$, beliau berkata bahwa: "Syarat ke-Islam-an" bagi seorang calon pemimpin dalam ajaran Islam itu adalah merupakan sesuatu yang mudah diketahui dari huku-hukum Islam"

\section{5) Tugas Dan Kewajiban Seorang Pemimpin Dalam Islam.}

Telah dijelaskan di dalam kitab-kitab siyasah syar'iyyah pada umumnya tentang kewajiban-kewajiban seorang pemimpin atau seorang kepala negara (-) sebagaimana yang dijelaskan di dalam kitab al-Ahkâm as-Sulthôniyyah oleh AlMawardi, al-Ahkâm as-Sulthôniyyah oleh al-Farra', Tahrîru al-Ahkâm fi Tadbîri ב.

Ahli al-Islâm oleh Ibnu Juma'ah dan kitab-kitab klasik yang lainnya, jadi perkaraperkara yang merupakan kewajiban-kewajiban pemimpin negara itu, di antaranya $\circ$ adalah : ${ }^{56}$

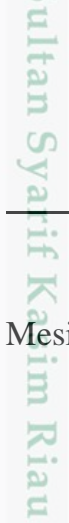

${ }^{55}$ Shalah al-Shawi Al-Wajîz fî̀ -Fiqhi Al-Khilâfah, Hal. (22-23)

${ }^{56}$ Dr. Khalid al-'Anbari, Fiqhu al-Siyâsah al-Syar'iyyah, Penerbit Dâru al-Minhaj Kairo Mesir, Tahun 1425H / 2005M, hal. 180-186. 
1. Seorang pemimpin itu wajib menjaga agama Islam itu di atas pokok-pokok ajarannya yang telah ditetapkan dalam kaidah-kaidahnya yang telah tersusun lengkap yang berdasarkan al-Kitab, al-Sunnah dan hal-hal yang telah disepakati oleh generasi salaful ummah, merekza telah menjelaskan hujjah-hujjah dalam beragama Islam, mereka telah menyebarkan ilmuilmu syar'i, dalam dakwah mereka, mereka juga mengagungkan ilmu dan ahlinya, dan mereka juga telah membantah subhat-subhat dan para ahlinya. Jika muncul ahli subhat maka mereka jelaskan hujjahnya dan kebenaran atasnya dan menghukumnya dengan apa yang pantas atasnya agar agama selalu terjaga.

Demikian juga seorang pemimpin itu wajib menegakkan syi'ar-syiar Islam seperti shalat lima waktu, shalat Jum'at, shalat 'Id, adzan, iqamah, khotbah, imamah shalat, puasa, haji, dan mempermudah pelaksanaan itu semua dan mengamankannya.

2. Seorang pemimpin itu wajib menjaga negeri Islam dan membelanya, berjihad melawan kaum musyrikin, memberantas perampok dan penjahat, mengatur pasukan dan menata gaji-gaji mereka.

3. Seorang pemimpin itu wajib berlaku adil karena keadilan adalah sebab kebaikan yang akan dirasakan secara lansung oleh rakyat dan negerinya.

4. Seorang pemimpin itu wajib menegakkan undang-undang syari'at Islam, dia juga wajib menjaga syari'at-syari'at Allah dari pelanggaranpelanggaran dan juga seorang pemimpin itu wajib menjaga hak-hak hamba-hamba Allah. 
5. Seorang pemimpin itu wajib memutuskan kasus-kasus dan hukum-hukum dengan mengangkat para petugas dan para hakim untuk mengadili kasuskasus perselisihan dan mencegah orang yang berbuat zhalim. Tidak mengangkat orang yang bertugas melaksanakan hal itu kecuali orang yang dia percaya agamanya, amanahnya, dan penjagaannya dari para ulama dan orang-orang yang shalih, dan orang-orang yang pantas melaksanakannya.

6. Seorang pemimpin itu wajib mengambil zakat-zakat dan jizyah (upeti) dari ahlinya, mengambil harta fai' dan kharraj pada tempatnya, dan menyalurkan hal itu pada penyaluran-penyalurannya yang syar'i dan tempat-tempatnya yang benar, dan menyerahkan urusan-urusan tersebut kepada para pegawai yang terpercaya. ${ }^{57}$

7. Seorang pemimpin itu wajib memilih orang-orang yang ahli lagi amanah di dalam pelaksanaan tugas-tugas dan pengurusan harta-harta negara dan kaum muslimi, tugas itu wajib diserahkan pada ahlinya dan harta-harta itu wajib diurus oleh orang-orang yang amanah.

8. Seorang pemimpin itu wajib mengecek pelaksanaan-pelaksanaan tugas para pegawainya dan bawahannya

9. Seorang pemimpin itu wajib mewujudkan kesejahteraan setiap rakyat.

10. Seorang pemimpin itu wajib selalu mengupayakan untuk mewujudkan hal yang paling utama dari seluruh segi kehidupan manusia. ${ }^{58}$

6) Macam-macam Kepemimpin Dalam Islam.

${ }^{57}$ Dr. Khalid al'Anbari, Fiqhu al-Siyâsah al-Syar'iyyah hlm. 180-186.

${ }^{58}$ Dr. Khalid al'Anbari, Fiqhu al-Siyâsah al-Syar'iyyah hlm. 180-186. 
Pengertian pemimpin dalam Al Qur'an dapat diterjemahkan dengan empat padanan kata yaitu: 1. Khalifah, dengan segala bentuk perubahan katanya, 2. Imam, dengan perubahan katanya, 3. Uli Amri. 4. Malik ${ }^{59}$.

Munurut Muhammad Rasyid Ridho rahimahullahu berkata dalam bukunya at-Khilafah beliau mendefinisikan tentang pemimpin (al-Khilafah), lalu ia berkata: al-khilafah, al-imamah al-'uzma, imaratul mukminin adalah 3 kata yang maknanya adalah satu yaitu pemerintahan secara Islam yang mengemban tugas o secara keseluruhan demi meraih kemaslahatan agama dan dunia ${ }^{60}$

Dalam istilah Islam pemimpin dikonotasikan dengan kata khalifah, amir atau imamah. Khalifah itu adalah pengganti yang menggantikan tempat orang lain yang lain dalam beberapa persoalan. Dengan demikian dapat dikatakan bahwa khalifah yang berarti pengganti telah berkembang menjadi titel atau gelaran bagi pemimpin tertinggi masyarakat Muslim sebagai gelar yang berlabel agama. ${ }^{61}$

Imamah berarti yang menjadi pemimpin, yang menjadi suri teladan atau contoh yang harus diikuti atau yang mendahului ${ }^{62}$ dan Amir mempunyai arti pemimpin (Qaid Zaim) dan dalam kamus Inggris "leader" itu diartikan dengan orang yang memerintah, komandan, kepala dan raja. ${ }^{63}$

\section{7) Kepemimpinan Non Muslim Dalam Literatur Islam}

Siapa saja yang beriman kepada Allah Subhânahu wa-Ta'âlâ dan hari akhir, maka permasalahan seperti ini sangatlah terang dan jelas baginya, sehingga

${ }^{59}$ M. Quraish Shihab, dalam bukunya Membumikan al Qur'an, (Penerbit Mizan, Bandung, Tahun 1992), hlm. 159

${ }_{61}^{60}$ Syekh Muhammad Rasyid Ridho, Al-Khilâfah Hal. 18

${ }^{61}$ J. Suyuti Pulungan, Fiqih Siyasah; Ajaran dan Pemikiran, Jakarta; PT.Raja Grafindo Persada, Cet III, 1997, Ed. I h., 48-49

${ }^{62}$ Ibid., h., 59

${ }^{63}$ J. Suyuti Pulungan, Fiqih Siyasah; Ajaran dan Pemikiran, Jakarta. Hal., 63 
tidak ada yang perlu diragukan lagi, dengan mentela'ah permasalahan ini secara mendalam maka semakin menambah keyakinannya kepada kebenaran agama Islam yang sumber utamanya adalah wahyu dari langit yaitu al-Qur'an, al-Sunnah dan sumber-sumber lainnya yang terkait, pentela'ahan ini penulis awali pada point-ponit berikut ini:

\section{A. Kepemimpinan Non Muslim Berdasarkan Al-Qur'an}

a. Nash al-Qur'an telah melarang kaum muslimin untuk menjadikan non Muslim sebagai pemimpin

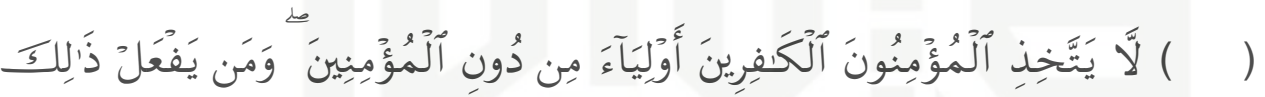

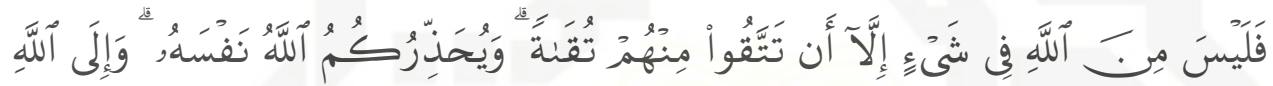

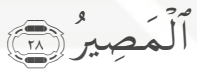

"Janganlah orang-orang mukmin mengambil orang-orang kafir menjadi wali (pemimpin/pelindung) dengan meninggalkan orang-orang mukmin. Barang siapa yang berbuat demikian, niscaya lepaslah dia dari pertolongan (jaminan) Allah, kecuali karena (siasat) memelihara diri dari sesuatu yang ditakuti dari mereka. Dan Allah memperingatkan kamu terhadap diri (siksa)-Nya. Dan hanya kepada Allah tempat kembali(mu)" (QS. 3/Ali 'Imrân : 28) ${ }^{64}$

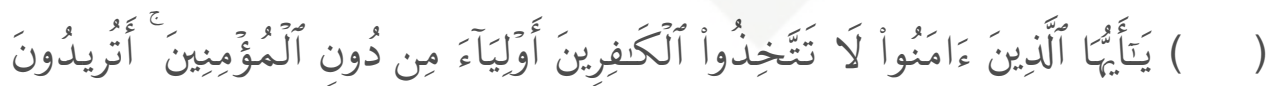

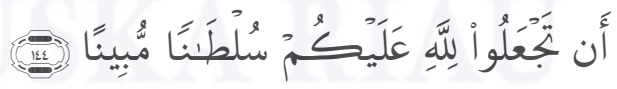

"Hai orang-orang yang beriman, janganlah kamu mengambil orang-orang kafir menjadi wali (pemimpin/pelindung) dengan meninggalkan orang-

${ }^{64}$ Departemen Agama RI, Al-Qur'an dan Terjamahannya 
orang mukmin. Inginkah kamu mengadakan alasan yang nyata bagi Allah (untuk menyiksamu) ? (QS. Al-Nisâ'/4 : 144) ${ }^{65}$

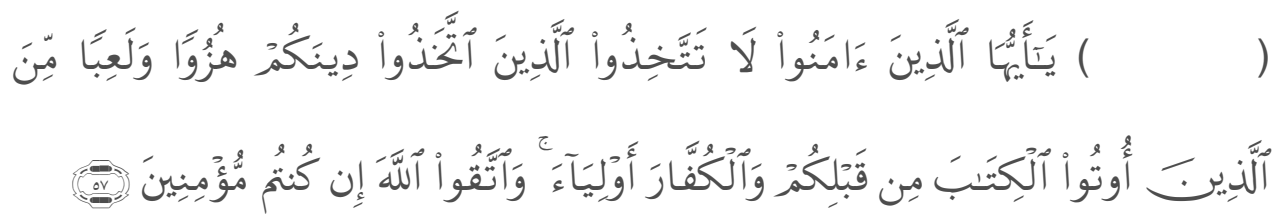

"Hai orang-orang yang beriman, janganlah kamu mengangkat orang yang menjadi pemimpinmu orang-orang yang menjadikan agamamu ejekan dan permainan, (yaitu) orang-orang yang telah diberi Al-Kitab sebelummu, dan orang-orang yang kafir (musyrik). Dan bertakwalah kepada Allah jika kamu betul-betul orang-orang yang beriman." (QS. Al-Mâ-idah/5 : 57) ${ }^{66}$

b. Nash al-Qur'an telah melarang kaum muslimin menjadikan non Muslim sebagai pemimpin walaupun dia kerabat sendiri.

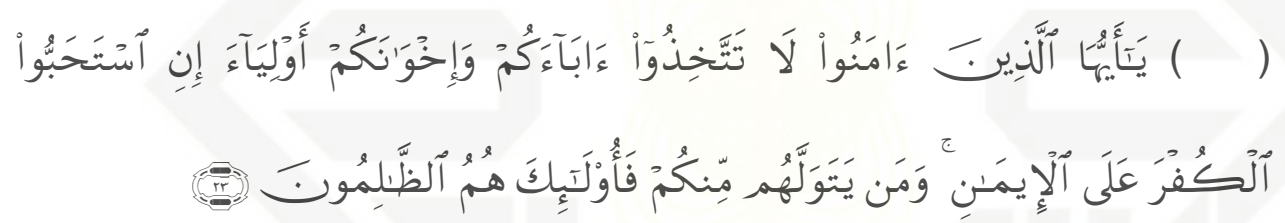

"Hai orang-orang beriman, janganlah kamu jadikan bapak-bapakmu dan saudara-saudaramu menjadi wali (pemimpin/pelindung) jika mereka lebih mengutamakan kekafiran atas keimanan, dan siapa di antara kamu yang menjadikan mereka sebagai walinya, maka mereka itulah orang-orang yang zalim." (QS. Al-Taubah/9 : 23) ${ }^{67}$

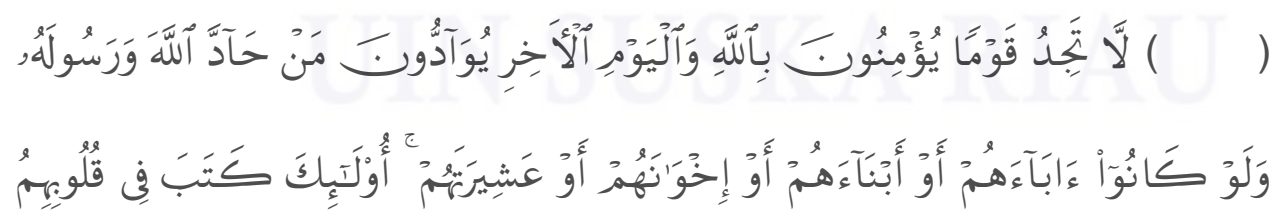

${ }^{65} \mathrm{Ibid}$.

${ }^{66}$ Ibid..

${ }^{67}$ Departemen Agama RI, Al-Qur'an dan Terjamahannya. 


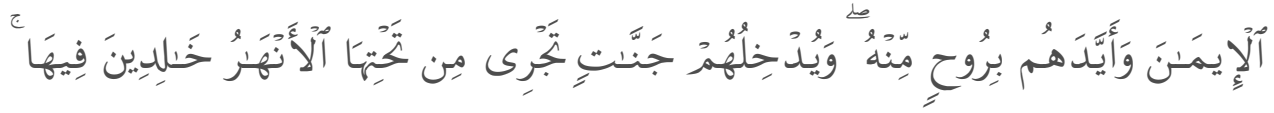

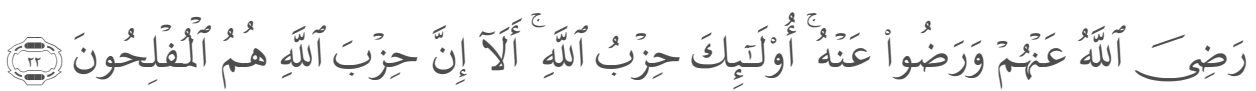

"Kamu tak akan mendapati kaum yang beriman pada Allah dan hari akhirat, (yang mereka) saling berkasih-sayang dengan orang-orang yang menentang Allah dan Rasul-Nya, sekali pun orang-orang itu bapak-bapak mereka, atau anak-anak mereka atau saudara-saudara mereka atau pun keluarga mereka. Mereka itulah orang-orang yang telah Allah tanamkan keimanan ke dalam hati mereka dan Dia (Allah) menguatkan mereka dengan pertolongan yang datang daripada-Nya. Dan Dia (Allah) memasukan mereka ke dalam surga yang mengalir di bawahnya sungaisungai, mereka kekal di dalamnya. Allah ridha terhadap mereka, dan mereka pun merasa puas terhadap (limpahan rahmat)-Nya. Mereka itulah golongan Allah. Ketahuilah, bahwa sesungguhnya hizbullah itu adalah golongan yang beruntung." (QS. Al-Mujâdilah/58 : 22) ${ }^{68}$

c. Nash al-Qur'an telah melarang umat Islam untuk menjadikan non Muslim sebagai teman setia, teman dekat atau teman kepercayaan

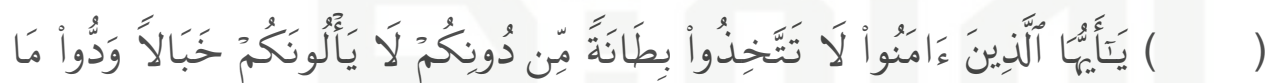

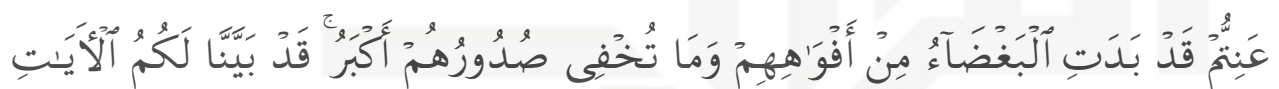

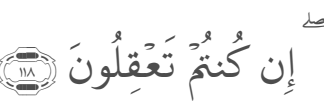

"Hai orang-orang yang beriman, janganlah kamu ambil menjadi teman kepercayaanmu orang-orang yang di luar kalanganmu (non muslim) (karena) mereka tidak henti-hentinya (menimbulkan) kemudharatan bagimu. Mereka menyukai apa yang menyusahkan kamu. Telah nyata kebencian dari mulut mereka, dan apa yang disembunyikan oleh hati

${ }^{68}$ Ibid. 
mereka adalah lebih besar lagi. Sungguh telah Kami terangkan kepadamu ayat-ayat (Kami), jika kamu memahaminya." (QS. 3/Âli 'Imrân : 118) ${ }^{69}$

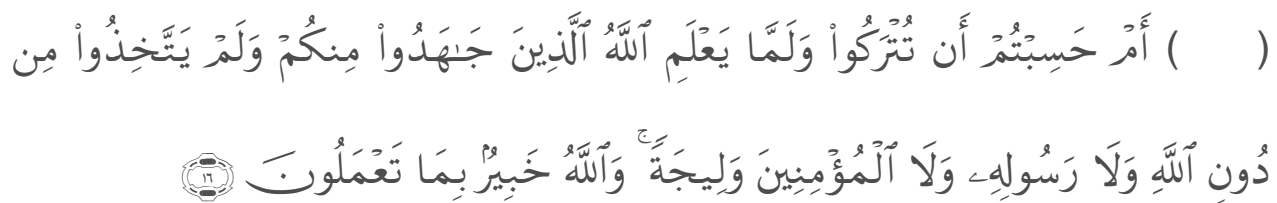

"Apakah kamu mengira bahwa kamu akan dibiarkan (tanpa ujian), sedangkan Allah belum mengetahui (dalam kenyataan) (siapakah) orangorang yang berjihad di antara kamu dan tidak mengambil menjadi teman setia selain Allah, Rasul-Nya dan orang-orang yang beriman? Dan Allah Maha Mengetahui apa yang kamu kerjakan." (QS. Al-Taubah/9 : 16) ${ }^{70}$

d. Nash al-Qur'an melarang umat Islam untuk saling tolong menolong dengan orang kafir yang akan merugikan umat Islam

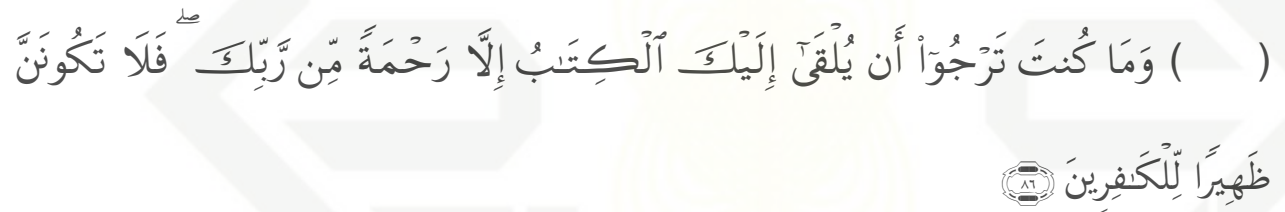

"Dan kamu tidak pernah mengharap agar Al-Quran diturunkan kepadamu, tetapi ia (diturunkan) karena suatu rahmat yang besar dari Tuhanmu, sebab itu janganlah sekali-kali kamu menjadi penolong bagi orang-orang kafir." (QS. Al-Qashash/28 : 86) ${ }^{71}$

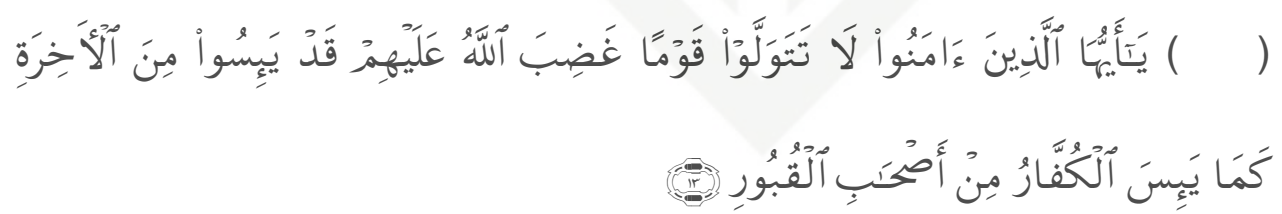

"Hai orang-orang yang beriman, janganlah kamu jadikan penolongmu kaum yang dimurkai Allah. Sesungguhnya mereka telah berputus asa

\footnotetext{
${ }^{69}$ Departemen Agama RI, Al-Qur'an dan Terjamahannya

${ }^{70}$ Ibid.

${ }^{71}$ Ibid.
} 
terhadap negeri akhirat sebagaimana orang-orang kafir yang telah berada dalam kubur berputus asa." (QS. 60/Al-Mumtahanah : 13) ${ }^{72}$

e. Nash al-Qur'an telah melarang umat Islam mentaati non Muslim untuk menguasai kaum muslimin

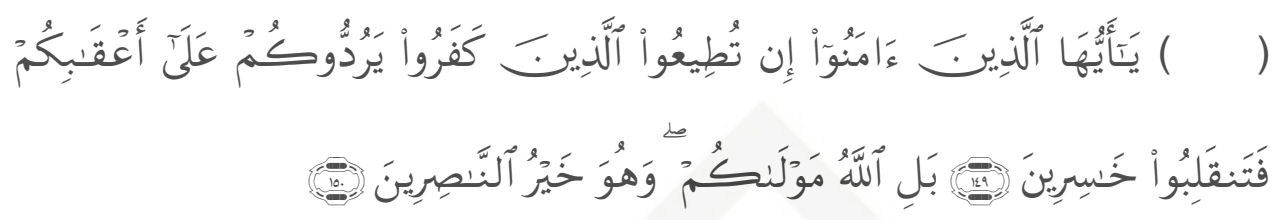

"Hai orang-orang yang beriman, jika kamu mentaati orang-orang kafir itu, yang mana mereka berusaha untuk mengembalikan kamu ke belakang (kepada kekafiran/memutadkan), lalu jadilah kamu orang-orang yang rugi. Tetapi (ikutilah Allah), Allahlah Pelindungmu, dan Dialah sebaikbaik Penolong." (QS. Âli 'Imrân/3 : 149-150) ${ }^{73}$

f. Nash al-Qur'an telah melarang umat Islam untuk memberikan peluang kepada orang kafir untuk menguasai kaum muslimin

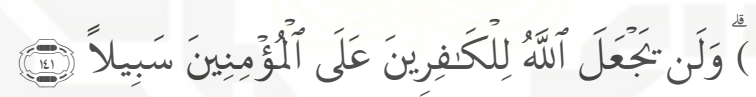

"... Dan Allah sekali-kali tidak akan memberikan jalan kepada orangorang kafir untuk menguasai orang-orang yang beriman." (QS. Al-Nisaa' $14: 141)^{74}$

g. Nash al-Qur'an telah memvonis munafiq apabila ada seseorang yang menjadikan non Muslim sebagai pemimpin

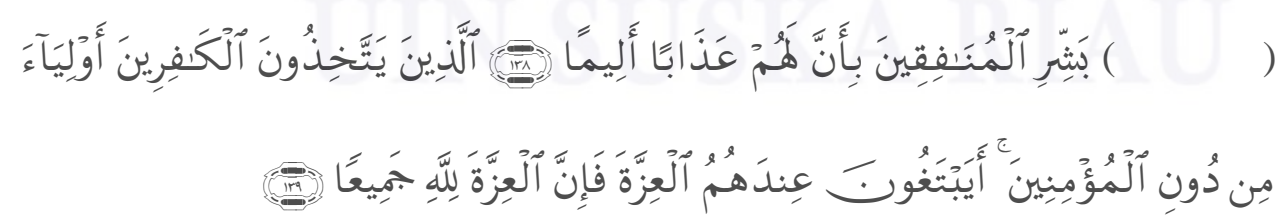

\footnotetext{
${ }^{72}$ Ibid.

${ }^{73}$ Departemen Agama RI, Al-Qur'an dan Terjamahannya.

${ }^{74}$ Ibid.
} 
"Kabarkanlah kepada orang-orang munafik bahwa mereka akan mendapat siksaan yang pedih. (yaitu) orang-orang yang mengambil orang-orang kafir menjadi teman-teman penolong dengan meninggalkan orang-orang mukmin. Apakah mereka mencari kekuatan di sisi orang kafir itu ? Maka sesungguhnya semua kekuatan kepunyaan Allah." (QS. AlNisâ' /4: 138-139) ${ }^{75}$

h. Nash al-Qur'an memvonis dzolim terhadap seseorang yang menjadikan non Muslim sebagai pemimpin

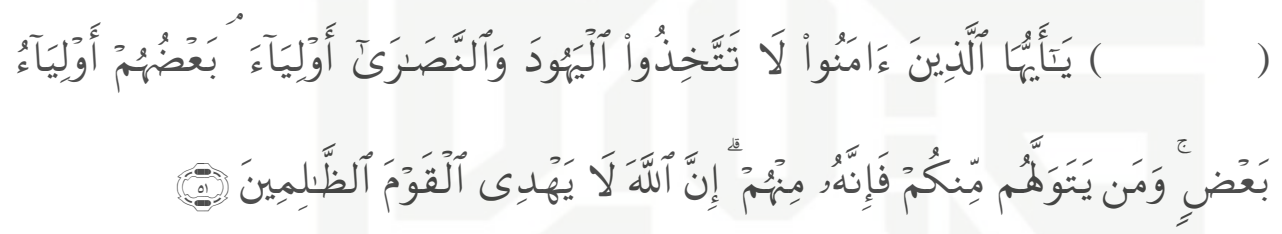

"Hai orang-orang yang beriman, janganlah kamu mengambil orangorang Yahudi dan Nasrani menjadi pemimpin-pemimpin(mu); sebahagian mereka adalah pemimpin bagi sebahagian yang lain. Barangsiapa diantara kamu mengambil mereka menjadi pemimpin, maka sesungguhnya orang itu termasuk golongan mereka. Sesungguhnya Allah tidak memberi petunjuk kepada orang-orang yang zalim." (QS. Al-Mâ-idah/5: 51) ${ }^{76}$

i. Nash al-Qur'an telah memvonis fasiq seseorang yang menjadikan kafir sebagai pemimpin

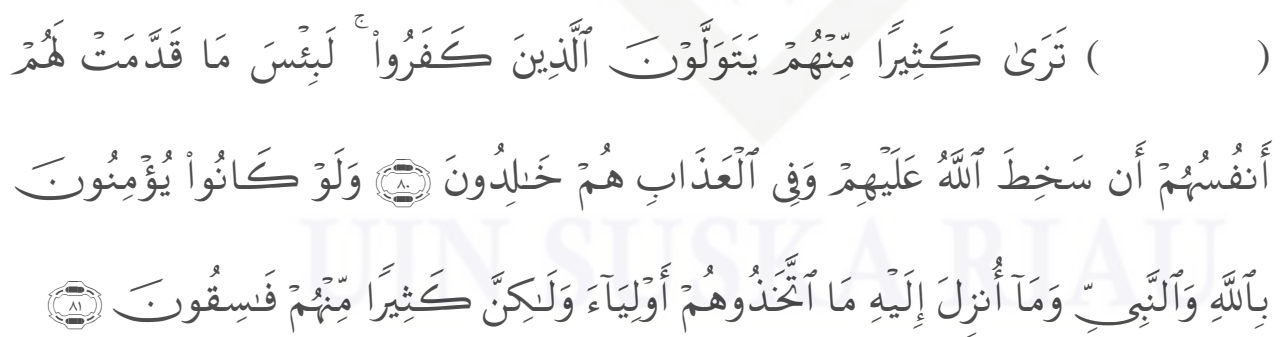

"Kamu melihat kebanyakan dari mereka tolong-menolong dengan orangorang yang kafir (musyrik). Sesungguhnya amat buruklah apa yang mereka sediakan untuk diri mereka, yaitu kemurkaan Allah kepada

${ }^{75}$ Departemen Agama RI, Al-Qur'an dan Terjamahannya

${ }^{76}$ Ibid. 
mereka; dan mereka akan kekal dalam siksaan. Sekiranya mereka beriman kepada Allah, kepada Nabi dan kepada apa yang diturunkan kepadanya (Nabi), niscaya mereka tidak akan mengambil orang-orang musyrikin itu menjadi penolong-penolong, tapi kebanyakan dari mereka adalah orangorang yang fasiq." (QS. Al-Mâidah/5: 80-81) ${ }^{77}$

j. Nash al-Qur'an telah memvonis "sesat" seseorang yang menjadikan orang kafir sebagai pemimpin

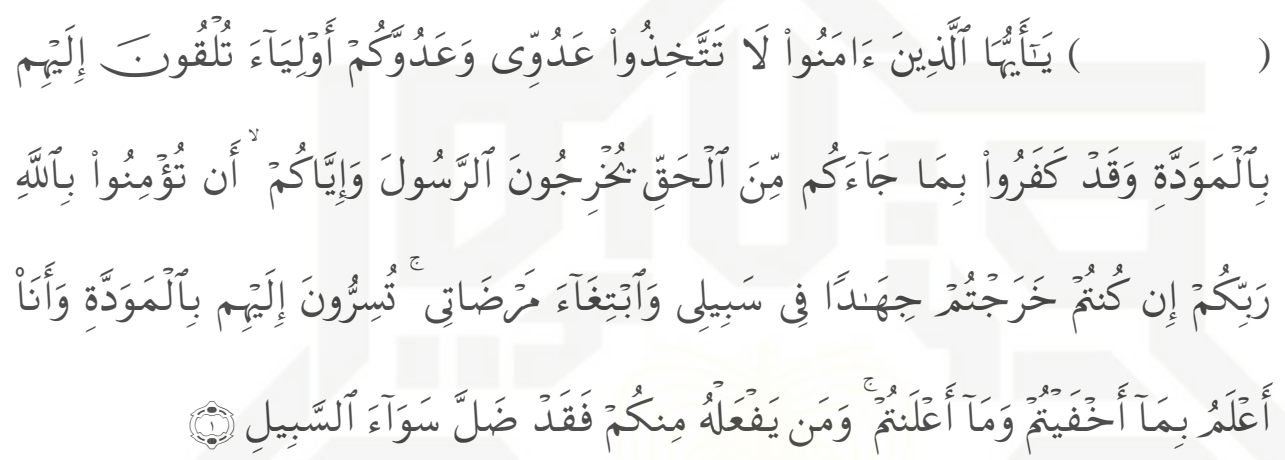

"Hai orang-orang yang beriman, janganlah kamu mengambil musuh-Ku dan musuhmu menjadi teman-teman setia yang kamu sampaikan kepada mereka (berita-berita tentang Muhammad), karena rasa kasih sayang; padahal sesungguhnya mereka telah ingkar kepada kebenaran yang datang kepadamu, mereka yang mengusir Rasul dan juga (mengusir) kaтu, karena sebab kamu beriman kepada Allah, Tuhanmu. Jika kamu benar-benar keluar untuk berjihad di jalan-Ku dan mencari keridhaan-Ku (janganlah kamu berbuat demikian). Кати memberitahukan secara rahasia (berita-berita tentang Muhammad) kepada mereka, karena rasa kasih sayang. Aku lebih mengetahui apa yang kamu sembunyikan dan apa yang kamu nyatakan. Dan barangsiapa di antara kamu yang melakukannya, maka sesungguhnya dia telah tersesat dari jalan yang lurus." (QS. Al-Mumtahanah/60:1) ${ }^{78}$

\footnotetext{
${ }^{77}$ Departemen Agama RI, Al-Qur'an dan Terjamahannya

${ }^{78}$ Ibid.
} 
k. Nash al-Qur'an mengancam dengan "azab yang sangat berat" bagi seseorang yang menjadikan non Muslim sebagai pemimpin atau teman setia.

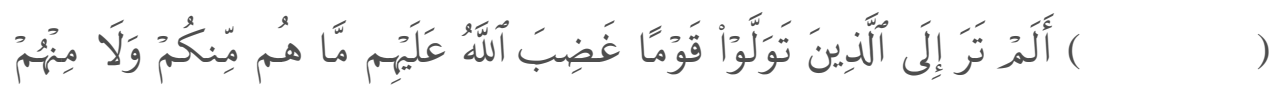

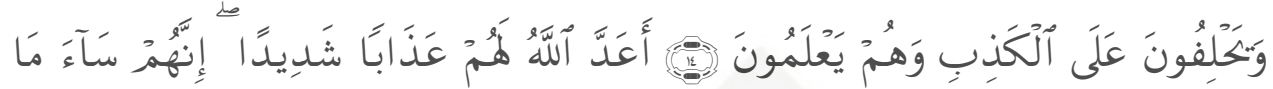

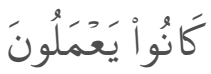

"Tidakkah kamu perhatikan orang-orang yang menjadikan suatu kaum yang dimurkai Allah sebagai teman ? Orang-orang itu bukan dari golongan kamu dan bukan (pula) dari golongan mereka. Dan mereka bersumpah untuk menguatkan kebohongan, sedang mereka mengetahui. Allah telah menyediakan bagi mereka azab yang sangat keras, sesungguhnya amat buruklah apa yang telah mereka kerjakan." (QS. AlMujâdilah/58 : 14-15) ${ }^{79}$

1. Nash al-Qur'an mengajarkan doa agar muslimin tidak menjadi sasaran fitnah orang-orang kafir

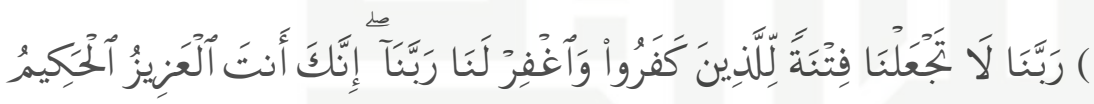

"Ya Tuhan kami, janganlah Engkau jadikan kami (sasaran) fitnah bagi orang-orang kafir. Dan ampunilah kami ya Tuhan kami. Sesungguhnya Engkaulah Yang Maha Perkasa lagi Maha Bijaksana." (QS. AlMumtahanah/60:5) ${ }^{80}$

B. Kepemimpinan Non Muslim Berdasarkam Hadits-hadits Rasulullah Shallallâhu 'Alaihi wa-Sallam

${ }^{79}$ Departemen Agama RI, Al-Qur'an dan Terjamahannya

${ }^{80}$ Ibid. 
a. Rasulullah shallallâhu 'alaihi wa-sallam melarang kaum muslimin untuk berteman dekat (bersahabat) dengan non-Muslim, maka larangan yang lebih utama adalah larangan untuk menjadikannya sebagai pemimpin.

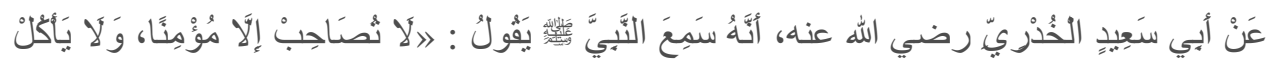
)$\ll$

"Dari Abu Sa'id al-Khudri radhiyallâhu 'anhu, dia berkata bahwa Rasulullah shallallâhu 'alaihi wa-sallam bersabda: "Janganlah engkau bersahabat kecuali hanya dengan orang mukmin, dan janganlah orang yang memakan makanmu kecuali orang yang bertakwa”. (HR. Tirmizi) ${ }^{81}$

Pelajaran yang terkandung dalam hadits ini adalah bahwa Rasulullah shallallâhu 'alaihi wa-sallam melarang kita agar tidak bersahabat akrab dan berteman setia kecuali hanya dengan orang Islam bukan dengan non-Muslim, artinya untuk bersahabat dengan non-Muslim saja kita dilarang, maka yang lebih terlarang lagi adalah menjadikan nonMuslim itu sebagai pemimpin (qiyas aula)

b. Rasulullah shallallâhu 'alaihi wasallam mengajarkan kaum muslimin agar mereka mengangkat seorang pemimpin itu adalah seorang laki-laki muslim, bukan laki-laki non Muslim

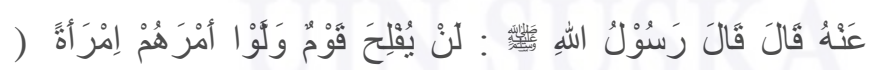

"Dari Abu Bakroh radhiyallâhu 'anhu, dia berkata bahwa Rasulullah shallallâhu 'alaihi wasallam bersabda: "Tidak akan berhasil (baik) suatu

${ }^{81}$ Al-Tirmizi, Sunan At-Tirmidzi (No. 2395), Abu Daud, Sunan Abu Daud (No. 4832) 


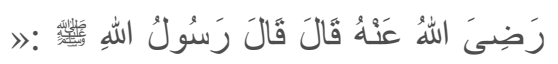

Dari Abu Zar radhiyallâhu 'anhu, dia berkata Rasulullah shallallâhu 'alaihi wasallam bersabda: Amal yang paling utama (disisi Allah) adalah cinta karena Allah dan benci karena Allah (HR. Abu Daud) ${ }^{84}$

Kandungan pelajaran dalam hadits ini adalah bahwa Rasulullah shallallâhu 'alaihi wasallam mengajarkan kepada kita agar mencintai orang-orang beriman karena mereka adalah kekasih Allah dan Rasulullah shallallâhu 'alaihi wasallam juga mengajarkan kepada kita agar membenci orang-orang kafir, karena mereka adalah musuh-musuh Allah, lalu bagaimana mungkin musuh Allah itu boleh diangkat menjadi pemimpin atas kaum muslimin.

d. Rasulullah shallallâhu 'alaihi wasallam mengajarkan kepada kita do'a agar bisa memusuhi orang-orang memusuhi Allah yaitu orang-orang kafir

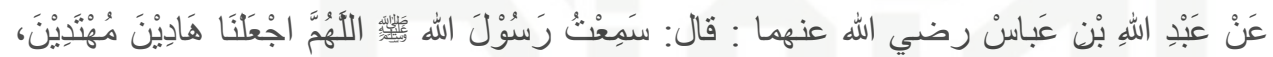

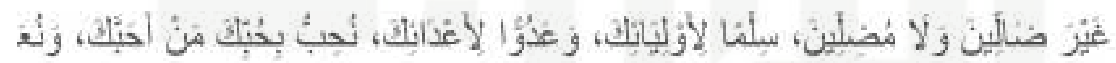

"Dari Abdullah bin Abbas radhiyallâhu 'anhuma, dia berkata saya mendengar Rasulullah shallallâhu 'alaihi wasallam berdo'a: "Ya Allah, jadikanlah kami orang-orang yang bisa memberi petunjuk (bagi orang lain) dan orang yang mendapat petunjuk (dari-Mu), janganlah Engkau jadikan kami termasuk orang-orang tersesat lagi menyesatkan, dan jadikanlah kami orang yang mendamaikan para kekasih-Mu dan bisa memusuhi musuh-musuhMu. Dengan dasar mencintai-Mu maka kami 20796)

${ }^{84}$ Abu Daud, Sunan Abu Daud (No. 4599), dan Ahmad bin Hanbal, Musnad Ahmad (No. 
dapat mencintai orang-orang yang mencintai-Mu, dan dengan dasar benci-Mu maka dapat (pula) kami dapat memusuhi (membenci) orangorang yang mendurhakai-Mu” (HR. Tirmizi).$^{85}$

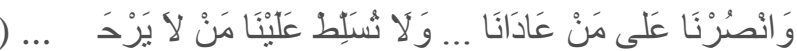

Rasulullah shallallâhu 'alaihi wasallam berdo'a: “Ya Allah .... tolonglah kami dalam menghadapi musuh-musuh kami ..... dan janganlah Engkau jadikan orang yang menguasai kami adalah orang yang tidak mencintai kami .... "(HR. Tirmizi) ${ }^{86}$

e. Rasulullah shallallâhu 'alaihi wasallam mengajarkan kepada kita do'a agar kita menasehati pemimpin kaum muslim (bukan mendo'akan non Muslim)

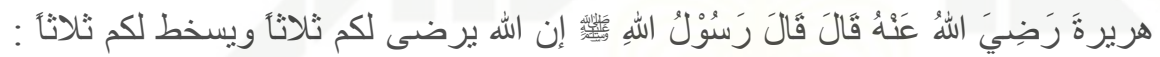
يرضى لكم أن تعبدوه و لا تشركوا به شيئا، وأن تعتصمو ا بحبل الله جميعاً ولا تفرقوا، وأن ويسخط لكم قيل وقال و إضاعة المال وكثرة السؤال (رواه أحمد :

Dari Abu Hurairoh radhiyallâhu 'anhu, ia berkata Rasulullah shallallâhu 'alaihi wasallam bersabda: "Sesungguh Allah ridho pada kalian pada tiga hal dan Dia membenci pada kalian pada tiga hal, Allah ridho pada kalian dalam tiga hal :

(1) Sembahlah Allah dan janganlah kalian berbuat syirik terhadapnya sedikitpun,

(2) Berpegang teguhlah dengan tali Allah (al-Qu'an dan as-Sunnah) dan jangan kalian bercerai berai

(3) Hendaklah kalian menasehati pemimpin kalian yang telah Allah pilih dia untuk memimpin kalian,

Dan Allah membenci tiga hal pada kalian yaitu :

(1) Allah membenci penukilan perkataan yang tidak jelas

${ }^{85}$ Al-Tirmizi, Sunan Al-Tirmidzi (No. 3419)

${ }^{86}$ Ibid. (No. 3502) 
(2) Allah membenci perbuatan menyia-nyiakan harta

(3) Allah membenci perbuatan banyak bertanya (sesuatu yang bermanfaat) ${ }^{87}$

Juga Rasulullah shallallâhu 'alaihi wasallam bersabda dalam hadits yang lain ${ }^{88}$ :

$$
\text { ماجه }
$$<smiles>[AlH2][AlH2]</smiles>

بغير

Tidaklah suatu kaum berhukum dengan apa yang tidak Allah turun (tidak berhukum dengan syari'atNya), maka pasti Allah akan turunkan pada kaum tersebut kerusakkan diantara mereka”. (HR. Ibnu Majah)

Jadi sudah dapat dipastikan apabila pemimpinnya orang kafir maka secara otomatis dia tidak akan berhukum dengan hukum Allah (al-Qur'an dan alSunnah), oleh karena itu haram bagi kaum muslimin untuk memilih pemimpin dari kalangan non Muslim.

\section{Kisah Umar bin Khattab Yang Memarahi Abu Musa Al-Asy'ari}

Mari kita mentela'ah kisah ini dengan sebaik-baiknya, agar kiranya kita bisa mengambil pelajaran penting dari sejarah para shahabat Rasulullah shallallâhu 'alaihi wasallam dalam beriteraksi dengan masyarakat non Muslim

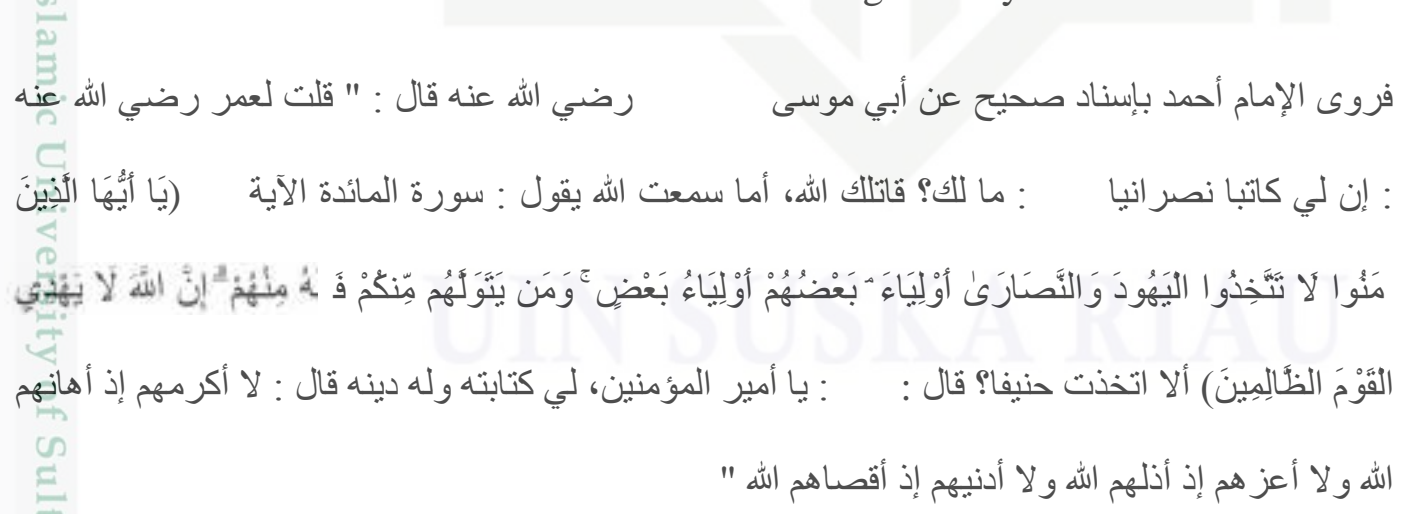

${ }^{88}$ Ibnu Taimiyyah, Al-Muntakhob min Kutub Syekh al-Islam Ibnu Taimiyyah, Hal. 132 
Imam Ahmad telah meriwayatkan dengan sanad yang shahih, dari Abu Musa radhiyallâhu 'anhu, beliau berkata: "Saya pernah berkata kepada Umar radhiyallahu 'anhu, sesungguhnya saya ini punya seorang juru tulis beragama Nasrani”, maka Umar berkata : Apa yang engkau katakan (wahai Abu Musa)? Semoga Allah memerangimu! Tidakkah engkau mendengar firman Allah (alMaidah ayat 51) : "Hai orang-orang yang beriman janganlah kalian mengambil ō̄ang-orang Yahudi dan Nasrani menjadi wali-wali kalian (orang kepercayaanmu, teman setiamu, pemimpin-pemimpinmu); yang mana sebagian mereka berloyalitas terhadap sebagian yang lainnya" Kenapa engkau (wahai Abu Musa) tidak mengangkat orang yang hanif (seorang muslim yang berjiwa lurus)? Kemudian Abu Musa berkata : wahai Amirul Mukminin yang saya ambil darinya hanya hanya tulisannya saja dan sedangkan agamanya adalah urusan dia sendiri. Maka Umar berkata: "Jangan engkau hormati mereka sedangkan Allah menghinakan mereka, jangan engkau memuliakan mereka sedangkan Allah merendahkan mereka, jangan engkau jalin hubungan dekat dengan mereka sedangkan Allah menjauhkan mereka, (HR. Ahmad)

Setelah Ibnu Taimiyyah membawakan kisah kemarahan Umar kepada Abu Musa Al-Asy'ary sebagaimana tersebut di atas, maka beliau rahimahullah mengungkapkan dengan sangat tegas untuk mengharamkan kaum muslimin untuk mengangkat non Muslim menjadi pemimpin, atau memegang peranan-peranan strategis lainnya, sebagaimana ia katakan :

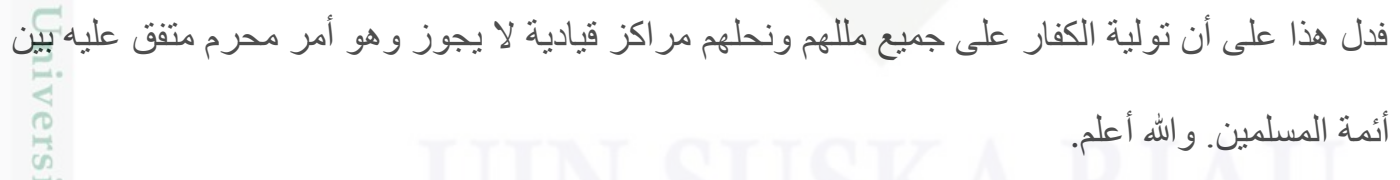

"Maka hal ini menunjukkan bahwa tidak boleh menyerahkan jabatanjabatan strategis kepada orang-orang kafir apapun agama mereka dan keyakinan mereka, hal itu adalah diharamkan menurut kesepakatan para imam kaum muslimin" wallahu 'alam. ${ }^{89}$

\section{Kepemimpinan Non Muslim Berdasarkan Ijma’ Ulama}

${ }^{89}$ Lihat, Iqtidhô al-Shiratil al-Mustaqim, oleh Syekhul Islam Ibnu Taimiyyah. (1/185) 
a. Seorang tokoh tersohor dari kalangan mazhab Maliki yaitu al-Imam Al-Qadhi Iyadh ${ }^{90}$ berkata:

$$
\text { ) أَنَّهُ }
$$

"Para ulama bersepakat bahwa kepemimpinan (Islam) tidak sah diberikan kepada orang kafir; dan bahkan bila pemimpin (Muslim) kemudian keluar dari Islam (murtad), maka dia wajib diturunkan" 91

Setelah menyebutkan perkataan Al-Qodhi Iyadh diatas, penyusun kitab asSiyâsah al-Syar'iyyah ${ }^{92}$ berkomentar:

过

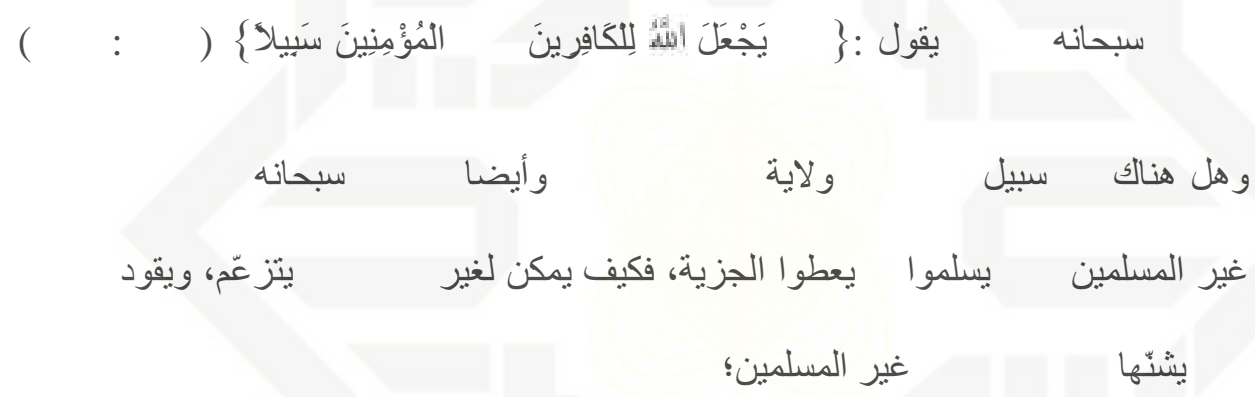

"Karena Allah Subhanahu Wa-Ta'ala berfirman (Dan Allah sekali-kali tidak akan memberikan jalan kepada orang-orang kafir untuk menguasai orang-orang yang beriman) (QS. An-Nisa': 141), masih adakah jalan yang lebih besar dalam menguasai (menjajah) kaum muslimin daripada memegang tampuk kepemimpinan, demikian juga Allah Subhanahu WaTa'ala telah memerintah kaum muslimin untuk memerangi orang-orang kafir hingga mereka masuk Islam atau mereka menbayar pajak, lalu bagaimana mungkin orangkafir itu diberi peluang untuk menjadi pemimpin atas kaum muslimin, lalu dia memimpin kaum muslimin melakukan peperangan melawan kaum kuffar (golongannya sendiri).

${ }^{90} \mathrm{Al}$ Qadhi Iyadh adalah Abu Al Fadhl Iyadh bin Musa bin Iyadh al Yahshabi al Andalusi al-Sabti al Maliki, seorang imam dan ulama serta hafizh dan juga seorang syaikh Islam. (476$544 \mathrm{H}$.

${ }^{91}$ Al-Nawawy, Al-Minhaj Syarhu Shahih Muslim, (6/314)

${ }^{92}$ Lihat Al-Siyasah al-Syar'iyyah, Muqorror Universitas Islam Madinah KSA Hal. 485-486 
b. Al-Imam Ibnu al-Mundzir ${ }^{93}$ menolak kepemimpinan Non Muslim di tengah kaum muslimin, maka dalam masalah beliau ini juga menukilkan Ijma’ ulama, kemudian dia mengatakan:

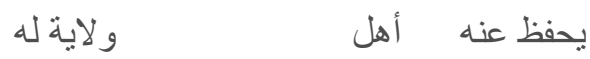

"Telah bersepakat (ijma') seluruh ahli ilmu (ulama) bahwa orang kafir sama sekali tidak boleh menjadi pemimpin atas kaum Muslimin dalam keadaan apapun." 94

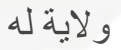$$
\text { يحفظ عنه أهل - مل }
$$

“Telah bersepakat (ijma') seluruh ahli ilmu (ulama) bahwa orang kafir sama sekali tidak boleh menjadi pemimpin atas kaum Muslimin dalam keadaan apapun."

c. Ibnu Taimiyyah juga menegaskan dalam kitabnya Iqtidhô al-Shirâtil al-Mustaqîm, tentang Ijma' Ulama agar kaum muslimin itu tidak menjadi pengekor orang-orang kuffar

$$
\text { فصل في الإجماع على الأمر بمخالفة الكفار و النهي عن مشابهته .... إجماع المسلمين على }
$$

Pasal tetang Ijma' : "Kaum muslimin diperintah agar mereka menyelisihi orang-orang kafir dan juga kaum muslimin dilarang untuk menyerupai orang-orang kafir... Telah Ijma' ulama kaum muslimin tentang wajibnya kaum muslimin untuk menyelisihi orang-orang kafir secara zahir (terangterangan), dan wajib juga kaum muslimin untuk tidak menyerupai mereka..." 95

${ }^{93}$ Zakiyyuddin Abdu al-'Adhim bin Abdu al-Qawiy bin Abdullah bin Salamah Abu Muhammad al-Mundziri (581-656 H)

${ }^{94}$ Ibnu Qoyyim Al-Jauziyyah, Ahkamu Ahli Al-Zimmah, karya Muhammad bin Abi Bakar bin Ayyub bin Sa'd Al-Zar'i Al-Dimasqi, kunyanya adalah Abu Abdillah Syamsuddin dan lebih dikenal dengan Ibnu Qoyyim Al-Jauziyyah (1/465)

${ }^{95}$ Lihat Iqtidhô al-Shirati al-Mustaqim, oleh Taqiyu Al-Dîn Abu Al-Abâs Ahmad bin Abdul Halim bin Taimiyyah Al-Harâny (1/406) 
Pernyataan Ibnu Taimiyyah diatas dengan sangat mudah dipahami, bahwa menyerupai non muslim sudah jelas larangannya, maka larangan untuk menjadikan mereka sebagai pemimpin tentu lebih utama untuk dilarang.

d. Al-Hafidz Ibnu Hajar al-Asqolany ${ }^{96}$ berkata:

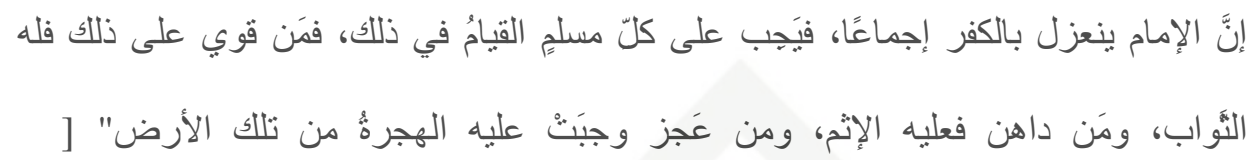

$\left[\begin{array}{lll}1 & :\end{array}\right.$

Ijma' kaum muslimin bahwa seorang pemimpin itu wajib dilenserkan karena sebab kekafirannya, dan wajib atas setiap muslim berdiri tegak menghadapi masalah itu, maka barangsiapa yang berusaha untuk menegakkan hal itu maka baginya ganjaran pahala dan barang siapa yang berbasa basi (masalah itu) maka dia akan menanggung dosa, dan barangsiapa yang lemah dalam menegakkan hal ini maka dia wajib hijrah dari bumi tersebut. ${ }^{97}$

\section{B. Biografi Ibnu Taimiyyah}

\section{1) Kelahiran Ibnu Taimiyyah}

Nama asli Ibnu Taimiyyah adalah Taqiyuddin Abu al-Abbas Ibnu Abd al-

Halim bin al-Imam Majduddin Abi al-Barakat Abdu al-Salam bin Muhammad bin Abdullah bin Abi Qasim Muhammad bin Khuddlarbin Ali bin Taimiyyah alHarraniy al Hambali. ${ }^{98}$

${ }^{96}$ Syihabuddin Abul Fadhl Ahmad bin Ali bin Muhammad bin Muhammad bin Ali bin Mahmud bin Ahmad bin Hajar, (773 H/1372 M - 852 H/1449 M)

${ }_{97}$ Ibnu Hajar Al-Asqolany, Fathu al-Bâri, (13/123)

${ }^{98}$ Jon Kamil, Tesis Perkawinan Antar Pemeluk Agama Perspektif Fiqh Ibnu Taimiyyah, (UIN Suska Riau : pasca sarjana,2011), hal.18 
Para ahli lebih singkat menyebut nama lengkapnya dengan Taqiyuddin

A $\bar{b} u$ al-Abbas bin Abdu al-Halim bin Abdu al-Salam bin Taimiyyah al-Haranyi al-Hambali. ${ }^{99}$

Namun orang lebih cepat mengenal namanya dengan sebutan Taqiyuddin

Ibnu Taimiyyah atau lebih populer Ibnu Taimiyyah saja. Beliau dilahirkan pada hari senin tanggal 10 Rabi'ul Awal tahun $661 \mathrm{H}$ bertepatan dengan tanggal 22 Januari 1263 M di kota Harran, ${ }^{100}$ yaitu daerah yang terletak ditenggara negeri Syam, tepatnya dipulau Ibnu Amr antara sungai Tigris dan Eupraht. ${ }^{101}$

Ibnu Taimiyah dari keluarga ulama Syiria yang setia pada ajaran agama puritan dan amat terikat dengan madzhab Hanbali. Sang kakek Abdus-Salam, adalah seorang ulama dan pengkaji (pemuka) agama terkemuka di Baghdad, ibukota kekhgalifahan Abbasiyah, dan kediaman yang disinggahinya pada tahuntahun akhir kehidupannya. Tradisi serupa diteruskan oleh putranya, Abdul Halim (ayah Ibnu Taimiyah), yang menjadi kepala sekolah ilmu hadits terkemuka di Damaskus, perbatasan dengan Haran yang menjadi basis perpindahan keluarganya setelah bangsa Mongol menjajah negeri itu. Banga Mongol menerjang kearah barat dan Iraq, setelah mengakhiri kekhalifahan Abbasiyah, sementara Syi'ah 3 berada di bawah pemerintahan bangsa Mameluk yang berpusat di Kairo. ${ }^{102}$

Ibnu Taimiyyah lahir dari keluarga cendikiawan dan ilmuan terkenal. Ayahnya Syaibuddin Abu Ahmad adalah seorang syaikh, khotib hakim dikotanya. Sedangkan kakeknya, syaikh Islam Majduddin Abu al-Birkan adalah fakih

${ }^{99}$ Khalid Ibrahim Jindan, Teori Politik Islam : Telaah Kritis Ibnu Taimiyyah tentang Pemerintahan Islam, Alih bahasa Masrinin, (Penerbit Risalah Gusti, Jakarta Tahun 1995), hal. 24

${ }^{100}$ Syaikh Ahmad Farid, 60 Biografi Ulama Salaf, Terjemahan Masturi Irham dan Assmu’i Taman, (Penerbit Pustaka Al-Kautsar, Jakarta 2006), Cet.ke-1, hal. 784

${ }^{101}$ Ibnu Taimiyah, Al-Furqôn baina Auliyâ' al-Rahmân wa Auliyấ' al-Syithôn, Alih bahasa Abd Azia Mr, (Yogyakarta: Mitra Pustaka,2005), h.11

${ }_{102}$ Khalid Ibrahim Jindan, op.cit, hal.24 
Hambali, Imam, ahli hadits, ahli-ahli ushul, nahwu seorang hafiz, dan pamannya bernama Fakhruddin yang terkenal sebagai seorang cendekiawan dan penulis Muslim ternama. Pada tahun 1268 M, Ibnu Taimiyyah dibawa mengungsi oleh keluarganya ke Damaskus. Karena pada ketika itu bencana besar menimpa umat Istam, bangsa Mongolia menyerang secara besar-besaran kota kelahiran Ibnu Taimiyyah. Bangsa Mongol memusnahkan kekayaan intelektual Muslim serta Z

Metropolotan yang berpusat di Bagdad. Dan seluruh warisan Intelektual dibakar $\stackrel{\circ}{\infty}$ dān dibuang ke sungai Tigris. ${ }^{103}$

Ketika pindah ke Damaskus, Ibnu Taimiyyah baru berusia enam tahun. Setelah ayahnya wafat pada tahun 1284, Ibnun Taimiyyah yang baru berusia 21 tahun,menggantikan kedudukan sang ayah sebagai guru dan khatib pada masjidmasjid sekaligus mengawali karirnya yang kontroversial dalam kehidupan masyarakat sebagaiteolog yang aktif. Ibnu Taimiyah dikenal sebagai seorang pemikir, tajam intuisi, berpikir dan bersikap bebas, setia pada kebenaran, piawai dalam berpidato dan lebih dari itu, penuh keberanian dan ketekunan. Ia memiliki semua perssyaratan yang menghantarkannya pada pribadi luar biasa. ${ }^{104}$

\section{2) Pendidikan Ibnu Taimiyyah}

Ibnu Taimiyyah tumbuh berkembang dalam penjagaan yang sempurna dan sederhana dalam pakaian dan makanan. Ia terus melakukan demikian sampai akhir hayatnya. Disamping itu, ia juga sangat berbakti kepada orang tuanya, bertakwa, berwira'i, beribadah, banyak berpuaa,sholat, dzikir kepada Allah, berhenti pada batas-batas-Nya berupa perintah dan larangan-Nya, menyuruh melakukan perbuatan yang makruf dan mencegah perbuatan yang mungkar. Jiwanya hampir Pamaruddin Khan, Pemikiran Politik Ibnu Taimiyah, Ali bahasa Anas M, (Penerbit Pustaka, Bandung Tahun 1983), hal. 11

${ }^{104}$ Khalid Ibrahim Jindan, op.cit, hal. 25 
tidak pernah kenyang dengan ilmu, tidak puas dari membaca, tidak bosan mengejar dan tidak pernah berhenti meneliti. ${ }^{105}$

Ibnu Taimiyyah tumbuh dalam lingkungan keluarga yang berpendidikan tinggi. Ia mulai belajar agama ketika ia masih kecil, berkat kecerdasan dan kejeniusannya Ibnu Taimiyyah yang masih berusia muda sudah dapat menghafal Al-Qur'an dan telah mampu menamatkan sejumlah mata pelajaran seperti tafsir, hadits, fiqh, matematika dan filsafat, serta berhasil menjadi yang terbaik diantara os teman-teman seperguruannya. ${ }^{106}$

Ibnu Taimiyyah belajar teologi Islam dan Hukum Islam dari ayahnya sendiri. Disamping itu ia juga belajar dari ulama-ulama hadits yang terkenal. Guru Ibnu Taimiyyah berjumlah kurang lebih 200 orang, diantaranya adalah Syamsuddin al-Maqdisi, Ahmad bin Abu bin al-Khair, Ibnu Abi al-Yusr dan alKamal bin Abdul Majd bin Asakir ${ }^{107}$

Disamping itu ia juga mempelajari hadits sendiri dengan membaca berbagai buku yang ada. Ketika berusia tujuh belas tahun, Ibnu Taimiyyah telah diberi kepercayaan oleh gurunya Syamsuddin al-Maqdisi untuk mengeluarkan fatwa. Pada saat yang bersamaan, ia juga memulai kiprahnya sebagai seorang guru. Ketekunan Ibnu Taimiyyah dalam mempelajari ilmu yang berkaitan dengan hadits membuatnya menjadi seorang ahli hadits dan ahli hukum. Ia sangat के menguasai Rijal al-hadits (para tokoh perawi hadits) baik yang shahih, hasanatau dhoif. ${ }^{108}$

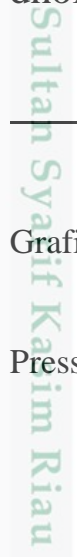

${ }^{105}$ Syaikh Ahmad Farid, op.cit, hal.787

${ }^{106}$ Adiwarman Azwar Karim, Sejarah Pemikiran Ekonomi Islam, (Penerbit PT. Raja Grafindo Persada, Jakarta, Tahun 2006), hal.351.

${ }^{107} \mathrm{Ibid}, \mathrm{h} .351$

${ }^{108}$ Munawir Sjadzali, Islam dan Tata Negara : Ajaran, Sejarah dan Pemikiran (Penerbit UI Press, Jakarta, Tahu 1990), hal. 79 
Sebagai ilmuan, Ibnu Taimiyyah mendapat reputasi yang sangat luar biasa dikalangan ulama ketika itu, ia dikenal sebagai orang yang berwawasan luas, pendukung kebebasan berpikir, tajam perasaan, teguh pendirian dan pemberani serta menguasai berbagai disiplin keilmuan yang dibutuhkan ketikaitu. Ia bukan hanya menguasai studi Al-Qur'an, Hadits dan Bahasa Arab, tetapi ia juga mendalami Ekonomi, Matematika, Sejarah Kebudayaan, Kesustraan Arab, Mantiq, Filsafat dan berbagai analisa persoalan yang muncul pada saat itu. $\frac{\sim}{\infty}$

Kedalaman ilmu Ibnu Taimiyyah memproleh penghargaan dari pemerintah pada

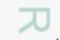
saat itu dengan menawarinya jabatan kepala kantor pengadilan. Namun, karena hati nuraninya tidak mampu memenuhi berbagai batasan yang ditentukan penguasa, ia pun menolak tawaran tersebut. ${ }^{109}$

Ibnu Taimiyyah menyelesaikan pendidikannya dalam bidang yurisprudensi (Fiqh), hadits nabi, tafsir al-Qur'an, matematika dan filsafat pada usia yang sangat muda. Disebabkan oleh pemikirannya yang revolusioner yakni gerakan tajdid (pembaharu) dan ijtihadnya dalam bidang muamalah, membuat namanya terkenal diseluruh dunia. ${ }^{110}$

Ibnu Taimiyyah, dia juga dikenal sebagai seorang pembaharu, dengan pengertian memurnikan ajaran Islam agar tidak tercampur dengan hal-hal yang berbau bid'ah. Diantara elemen gerakan reformasinya, adalah : pertama, melakukan reformasi melawan praktek-praktek yang tidak Islami. Kedua, kembali kearah prioritas fundamental ajaran Islam dan semangat keagamaan yang murni, ב sebaliknya mempedebatkan ajaran yang tidak fundamental dan sekunder. Ketiga, berbuat untuk kebaikan publik melalui intervensi pemerintah dalam kehidupan

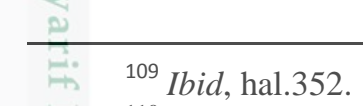

${ }^{110}$ Euis Amalia, Sejarah Pemikiran Ekonomi Islam dari Masa Klasik hingga Kotemporer, (Depok: Gramata Publishing, 2010), hal. 206. 
ekonomi, mendorong keadilan dan keamanan publik serta menjaga mereka dari sikap eksploitatif dan mementingkan diri sendiri. ${ }^{111}$

Cabang ilmu pengetahuan yang ditekuni Ibnu Taimiyyah adalah Teologi. Disamping itu, ia juga secara khusus mempelajari hukum dari mazhab Imam Hambali, dimana ayahnya merupakan tokoh yang sangat penting. Sehingga ia menjadi seorang mujtahid mutlak dan ahli kalam yang disegani pada masanya. Ibnu Taimiyyah dipandang sebagai salah seorang diantara para cendekiawan yang paling kritis dan yang paling kopenten dalam menyimpulkan peraturan-peraturan hukum-hukum dari Al-Qur'an dan hadits. Semangat dan pemikirannya serta penyelidikannya yang bebas dan tegar, ia dipandang sebagai bapak spiritual dalam gerakan modernisasi Islam disseluruh dunia. ibnu Taimiyyah meninjau berbagai masalah tanpa dipengaruhi apapun kecuali Al-Qur'an, As-Sunnah dan praktek para sahabat Rasulullah serta beberapa tokoh sesudah mereka. ${ }^{112}$

Ibnu Taimiyyah mempunyai banyak karya tulis dan komentarkomentar dalam ilmu ushul dan ilmu furu'. Kitab-kitab karyanya tersebut sudah ada yang disempurnakan dan ada yang belum dissempurnakan. Banyak ulama yang semasa dengannya memujinya atas karya-karyanya itu, seperti Al-Qadhi Al-Khaubi, ibnu Daqiq Al-Id, Ibnu An-Nuhas, Al-Qadhi Al-Hanafi, hakim agung Mesir (Ibnu AlHariri), Ibnu Az-Zamlakani dan ulama-ulama yang lain. ${ }^{113}$

\section{3) Karir dan perjuangan Ibnu Taimiyyah}

Sewaktu ayahnya wafat pada tahun 682H / 1284M, Ibnu Taimiyyah yang ketika itu berumur 21 tahun, menggantikan jabatan penting ayahnya sebagai $\exists$

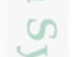

${ }^{111}$ Ibid, hal. 207

${ }^{112}$ Neni, Pemikiran Ibnu Taimiyyah Tentang Talqi al-Wafidain, (Pekanbaru: UIN Suska Riau, 2011), hal.13

${ }^{113}$ Syaikh Ahmad Farid, op.cit, hal.790 
pemegang Madrasah Dar al-Hadits as-Sukariyyah. Tanggal 2 Muharram 683 H / $1 \overline{284}$ M merupakan hari pertama Ibnu Taimiyyah mengajar di al-mamater yang kemudian dibawah pimpinannya. Setahun kemudian tepatnya pada tanggal 10 Safar 684 H / 17 April 1285 M, Ibnu Taimiyyah juga mulai memberikan kuliah umum di masjid Umayyah Damaskus dalam mata kuliah tafsir Al-Qur'an. ${ }^{114}$

Selain itu, Ibnu Taimiyyah juga menggantikan kedudukan ayahnya sebagai gưuru besar hadits dan fiqh Hambali dibeberapa Madrasah terkenal yang ada di Damaskus, mulai dari sinilah karir Ibnu Taimiyyah dikenal sebagai juru pengubah yang tidak rela menyaksikan kondisi umat Islam terbelenggu dengan pahampaham keagamaan yang junud, penuh dengan berbagai bid'ah dan khurafat yang ketika itu oleh Ibnu Taimiyyah dinilai sudah keterlaluan. Sehubungan dengan itu maka, Ibnu Taimiyyah berusaha untuk melakukan pemurnian dan pembaharuan dalam Islam. ${ }^{115}$

Ahli-ahli bid'ah dan khufarat merupakan musuh bebuyutan Ibnu Taimiyyah. Dia memerangi tanpa takut dan gentar, pendiriannya tegas dan kuat memegang prinsip. Ulama-ulama yang hidup pada zamannya banyak yang berusaha menyainginya, khususny mereka yang mempunyai kedudukanyang tinggi dan berpengaruh dimasyarakat. Ibnu Taimiyyah memerangi dengan pena dan kemahiran diplomasinya. Dia yakin bahwa pena lebih mapan untuk menghancurkan bid'ah dan khufarat yang mereka lakukan dari pada pedang ${ }^{116}$

Tulisannya yang menentang bid'ah, antara lain kitab Manasik al-Hajj, yang ia tulis untuk menentang berbagai bid'ah yang ditemuinya ditanah Mekkah

${ }^{114}$ B. Lewis,et. All, the Encyclopedia of Islam, (Laiden: E.J.Brill, 1979), jilid 3, hal. 951

${ }^{115}$ Muhammad Amin, Ijtihad Ibnu Taimiyyah Dalam Bidang Fiqh Islam, (Penerbit INIS Jakarta, Tahun 1991), hal. 12.

116 Muhammad Amin, Ijtihad Ibnu Taimiyyah Dalam Bidang Figh Islam, Disertasi Muhammad Amin, Cetakan 1991 hal. 780 
yang dinyatakan suci itu. Karena ketika ia menunaikan ibadah haji, pada tahun $6 \overline{91}$ H / 1292 M, Ibnu Taimiyyah merasa kecewa karena dibumi kelahiran Islam (Makkah al-Mukarramah), ia menyaksikan beberapa upacara dan kebiasaan yang dinilainya bid'ah. Begitu Ibnu Taimiyyah kembali dari Makkah, yakni pada thun $6 \overline{9}$ H / 1293 M, di Damaskus ia menulis kitab Manasik al Hajj. Seranganserangan terhadap bid'ah dan khurafat membutuhkan dendam kusumat dalam hati z sébahagian orang. Berkali-kali beliau difitnah orang karena keberaniannya co mengeluarkan pendapat yang bertentangan dengan pendapat orang banyak pada waktu itu, sehingga berulang-ulang ia ditangkap oleh penguasa dan hidupnya berpindah-pindah dari satu penjara ke penjara yang lain antara Damaskus dan Kairo pusat pemerintahan pada waktu itu dan ia tetap mengajar dan menulis meskipun dalam penjara. ${ }^{117}$

Ibnu Taimiyyah sangat keras dan sangat ketat dalam melaksanakan $A l$ amru bi al-ma'ruf wa al-nahyi 'an al-mungkar. Dia memikul sendiri tugas mengawasi manusia, besar ataupun kecil agar mereka sselalu menjaga adab sopan santun Islam dalam prilaku mereka. Seperti mengadakan razia keberbagai tempat orang mabuk-mabukan minum khamar dan arak di Syam.Perjuangan karirnya 当. dalam rangaka melakanakan al-amr bi al makruf wa al-nahyi 'an al-mungkar dan memurnikan akidah dan bid'ah dan khurafat penuh onak dan duri, penuh tuduhan क yang berakibat ia sering dipenjara.

Peristiwa pertama kali yang berkaitan ia harus dipenjara yakni ketika memprotes keras terhadap pemerintahan. Hal ini berkaitan dengan kasus 'Assaf an-Nasrani berkebangsaan Suwayda yang menghina Nabi Muhammad shallallahu

${ }^{117}$ B. Lewis, et. All, ed, loc.cit, hal. 951 
'alaihi wasallam. Ummat Islam setempat meminta kepada Gubernur Siria agar menghukum mati 'Assaf. Namun Gubernur Siria memberikan pilihan kepada 'Assaf antara memeluk agama Islam atau dijatuhi pidana mati. Dan 'Assaf memilih memeluk agama Islam, kemudian Gubernur Siria memaafkan 'Assaf, peristiwa naas itu terjadi pada tahun $693 \mathrm{H} / 1293 \mathrm{M} .^{118}$

Seusai menjalani hukuman penjara pada tanggal 17 Sya'ban 695 H / 20

Júni 1296 M, Ibnu Taimiyyah menjadi guru besar di Madrasah Hanbaliyyah, sūatu Madrasah yang tertua dan paling bermutu di Damaskus pada waktu itu. Pada tahun 705 H / 1306 M, ia kembali dijebloskan kepenjara di benteng Kairo, karena mempertanggung jawabkan tulisannya tentang sifatsifat Tuhan, yang dinilai penguasa menimbulkan keresahan dan kerisuhan. Dan Ibnu Taimiyyah dibebaskan pada tahun 702 H / 1306 M. Namun baru saja beberapa bulan ia dibebaskan masih dalam tahun yang sama Ibnu Taimiyyah harus berurusan lagi dengan pihak berwajib atas pengaduan kaum Sufi. Atas pengaduan kelompok Sufi ini, oleh penguasa Ibnu Taimiyyah disuruh memilih antara tinggal bebas di Damaskus atau Iskandariah dengan syarat harus menghentikan fatwa-fatwa dan kritiknya atau tinggal dilembaga permasyarakatan dalam waktu yang tidak ב.

ditentukan, yang kemudian Ibnu Taimiyyah dikucilkan dirumah tahanan Alexanderia. ${ }^{119}$

Selesai menjalani hukuman, pada tanggal 8 Syawal 709 H / 11 Maret 1310

M, Ibnu Taimiyyah kembali ke Kairo dan tinggal disana sekitar tiga tahun lamanya. Selama berdiam di Mesir, selain mengarang dan mengajar, Ibnu Taimiyyah juga menjawab berbagai persolan yang diajukan kepadanya (memberi 118 B. Lewis, et. All, ed, loc.cit. hal. 951
Jakarta: Tahun 2003), hal.149 
fatwa), dan kadang-kadang dijadikan konsultan oleh sultan Al-Malik al-Nasir, terutama masalah-masalah yang dihadapi orang-orang Siria.Pada Zulkaidah $712 \mathrm{H}$ / Februari 1313 M, Ibnu Taimiyyah yang ketika itu telah cukup lanjut usia ( sekitar 51 tahun ), beliau diperintahkan lagi pergi bertempur bersama-sama tentara Istam ke medan perang Yerussalem. Dan setelah ia menunaikan tugasnya dipalestina, ia kembali ke Damaskus, kota yang telah ditinggalkannya selama delapan tahun delapan minggu. Di Damaskus ia kembali mengajar sebagai profesor yang ulung. ${ }^{120}$

Ibnu Taimiyyah masih tetap melibatkan dirinya dalam kontroversi kancah perdebatan paham-paham ke Islaman, walaupun usianya telah bertambah lanjut, berbagai macam bentuk hukuman yang berkali-kali menimpa dirinya ternyata tidak mampu menggeserkan pendiriannya Ibnu Taimiyyah. Ia tidak pernah sanksi dalam mengemukakan dan mempertahankan kebenaran yang diyakininya walaupun dihadapan para ulama, para pejabat pemerintah dan sultan yang keras sekalipun.

Pada bulan Juli 1326 M / bulan Sya'ban 726 H, Ibnu Taimiyyah ditangkap lagi dan dimasukkan lagi kepenjara di benteng Damaskus. Keadaan ini ia gunakan dengan sebaik-baiknya untuk menulis tafsir Al-Qur'an dankarya-karya lainnya, tetapi kemudian jiwanya tersiksa, karena ketika itu ia tidak diizinkan lagi menulis dan seluruh tinta yang disediakan untuknya diambil semuanya. ${ }^{121}$

Tidak lama kemudian Ibnu Taimiyyah jatuh sakit dalam penjara. Sakitnya itu menelan waktu lebih dari dua puluh hari, menteri Syamsuddin meminta izin untuk menjenguknya, lalu diizinkanlah dia untuk itu. Setelah duduk disamping ${ }^{120}$ Ibnu Taimiyyah, Pedoman Islam Bernegara, Terjemahan Firdaus A.N, (Penerbit Bulan Bintang, Jakarta, Tahun 1977), hal.16.

${ }^{121}$ Ibnu Taimiyyah, Pedoman Islam Bernegara, Terj, Firdaus A.N, hal.18 
Ibnu Taimiyyah, ia meminta maaf atas kesalahannya. Maka Syaikh Ibnu Taimiyyah mengatakan kepadanya bahwa ia telah memaafkan nya karena ia melakukan kesalahannya bukan atas inisiatif pribadinya akan tetapi ikut orang lain. $^{122}$

Syaikh Ibnu Taimiyyah meninggal pada malam senin tanggal 20 Dzulqa'dah tahun 728 Hijriyah. Setelah kitab-kitabnya dikeluarkan dari penjara, Z iá terus membaca Al-Qur'an dan menghatamkannya setiap sepuluh hari sekali. ${ }^{123}$

\section{4) Guru-guru dan Murid-Murid Ibnu Taimiyyah}

\section{a) Guru-guru Ibnu Taimiyah}

Ibnu Taimiyah pernah belajar kepada banyak ulama, baik berjumpa dan hadir di majlis ulama-ulama besar di Damaskus secara langsung, maupun melalui telaah otodidak dan gurunya lebih dari dua ratus orang, diantaranya sebagai berikut : ${ }^{124}$

1. Zainuddin Ahmad bin Abdu Ad-da im Al-Maqdisi

2. Muhammad bin Ismail bin Utsman bin Muzhaffar bin Hibatullah Ibnu ‘Asakir Ad-Dimasyqi

3. Abdurrahman bin Sulaiman bin Sa'id bin Sulaiman Al-Baghdadi

4. Muhammad bin Ali Ash-Shabuni

5. Kamaluddin bin Abdul Azis bin Abdul Mun'im bin Al-Khidhr bin Syibl

6. Saifuddin Yahya bin Abdurrahman bin Najm bin Abdul Wahhab AlHanbali

7. Al-Mu`ammil bin Muhammad Al-baalisi Ad-Dimasyqi

8. Yahya bin Abi Manshur Ash-Shairafi

${ }^{122}$ Syaikh Ahmad Farid, op. cit, hal. 807

${ }^{123}$ Ibid, hal. 807

${ }^{124}$ Ibid, hal. 807-808 
9. Ahmad bin Abu Al-Khair Salamah bin Ibrahim Ad-Dimasyqi AlHanbali

10. Bakar bn Umar bin Yunus Al-Mizzi Al-Hanafi

11. Abdurrahim bin Abdul Malik bin Yusuf bin Qudamah Al-Maqdisi

12. Al-Muslim bin Muhammad bin Al-Muslim bin Muslim bin AlKhalafAl-Qisi

13. Al-Qasim bin Abu Bakar bin Al-Qasim bin Ghunaimah Al-Irbili

14. Ibrahim bin Ismail bin Ibrahim Ad-Darji Al-Qurasyi Al-Hanafi

15. Al-Miqdad bin Abu Al-Qasim Hibatullah Al-Qiisi.

16. Abdul Halim bin Abdus Salam bin Taimiyah, Ayahnya

17. Muhammad bin Abu Bakar Al-‘Amiri Ad-Dimasyqi

18. Ismail bin Abu Abdillah Al-'Asqalaani

19. Taqiyuddin Ismail bin Ibrahim bin Abu Al-Yusr At-Tannukhi

20. Syamsuddin Abdullah bin Muhammad bin Atha` Al-Hanafi. ${ }^{125}$

\section{b) Murid-murid Ibnu Taimiyyah}

Sebagai ulama yang terkenal sebagai sosok yang berfikir kritis dan tajam,

Ibnu Taimiyah memiliki banyak murid yang sangat banyak. Apalagi pada masa kehidupannya,kondisi umat Islam berada pada masa yang dikenal dengan nama "Jumud" ditambah lagi dengan adanya perang fisik dan fikiran antara क kekhalifahan Islam dengan non-Muslim, maupun perang pemikiran (Ghazwatul Fikri) antara aliran dn faham dalam Islam. Murid Ibnu Taimiyyah yang termashur ב diantaranya sebagai berikut ${ }^{126}$ :

${ }^{125}$ Syaikh Ahmad Farid, op. cit, hal. 807-808

${ }^{126}$ Syaikh Ahmad Farid, op. cit, hal. 808 
1. Syarafuddin Abu Muhammad Al-Manja bin Utsman bin Asad bin AlManja At-Tanukhi Ad-Dimasyqi

2. Jamaluddin Abu Al-Hajjaj Yusuf bin Az-Zakki Abdurrahman Bin Yusuf bin Ai Al-Mizzi

3. Syamsuddin Abu Abdillah Muhammad bin Ahmad bin Abdil Hadi

4. Syamsuddin Abdillah Muhammad bin Ahmad bin Utsman bin Qaimaz bin Abdillah Ad-Dimasyqi Adz-Dzahabi

5. Syamsuddin Abu Abdillah Muhammad bin Abi Bakar bin Ayyub yang terkenal dengan Ibnu Qayyim Al-Jauziyah

6. Shalahuddin Abu Said Khalil bin Al-Amir Saifuddin KaikaladiAl-Alai Ad-Dimasyqi

7. Syamsuddin Abu Abdillah Muhammad bin Muflih bin Muhammad bin Mufarraj Al-Maqdisi

8. Syarafuddin Abu Al-Abbas Ahmad bin Al-Hasan bin Abdillah bin Abi Umar bin Muhammad bin Abi Qudaimah

9. Imaduddin Abu Al-fida' Ismail bin Umar bin Katsir Al-Bashari Al-

Qurasyi Ad-Dimasqi.

10. 'Imaduddin Ahmad bin Ibrahim Al-Hizaam.

11. Al-Mufti Zainuddin Ubadah bin Abdul Ghani Al-Maqdisi AdDimasyqi

12. Taqiyuddin Abu Al-Ma'li Muhammad bin Rafi' bin Hajras bin Muhammad Ash-Shamidi As-Silmi, ${ }^{127}$

\section{5) Karya-karya Ibnu Taimiyyah}

${ }^{127}$ Syaikh Ahmad Farid, op. cit, hal. 808 
Salah satu unsur penting yang umum dijadikan dasar pertimbangan dalam menilai bobot keilmuan seseorang, terutama pada masa-masa sekarang ini ialah berupa banyak dan sejauh mana kualitas karya ilmiah yang sudah dihasilkannya. Dilihat dari sisi lain, Ibnu Taimiyyah tergolong sebagai salah satu pengarang produktif. Ia telah menghasilkan ratusan karya ilmiah yangbermutu, yang sangat bernilai bagi generasi-generasinya dengan berbagai judul dan tema, baik masalah aqidah, politik, hukum maupun filsafat.

Dikalangan para peneliti tidak terdapat kesatuan pendapat mengenai kepastian jumlah karya ilmiah Ibnu Taimiyyah, namun diperkirakan lebih dari 300-500 buah buku ukuran kecil dan besar, tebal dan tipis. Meskipun tidak semua karya tokoh ini tidak dapat diselamatkan,berkat kerja keras dua pengrang dari Mesir, yaitu 'Abd al-Rahman bin Muhammad bin Qasim yang dibantu putranya Muhammad bin 'Abd al-Rahman, sebahagian karya Ibnu Taimiyyah kini telah dihimpun dalam Majmu Fatawa Ibnu Taimiyyah yang terdiri dari 37 jilid

Karya-karya Ibnu Taimiyyah meliputi berbagai bidang keilmuan, seperti tafsir, hadits, ilmu hadits, ushul fiqh, tasawuf, mantiq, filsafat, politik, ilmu pemerintahan dan tauhid. Karya-karya Ibnu Taimiyyah antara lain: ${ }^{128}$

A. Tafsir wa' Ulum al-Qur'an

a. At-Tibyan fi nuzuli al-Qur'an

b. Tafsir surah al-Nur

c. Tafsir al-mu'udzatain

d. Muqaddimah fi 'ilm al-tafsir

B. Fiqh dan Ushul Fiqh

${ }^{128}$ Syaikh Said Abdul Azhim, Ibnu Taimiyah Pembaharuan Salafi dan Dakwah Reformasi, diterjemahkan oleh Faisal Saleh, Penerbit Pusstaka al-Kautsar, Jakarta, Tahun 2005, hal. 259 
a. Kitab fi ushul fiqh

b. Kitab manasiki al-haj

c. Kitab al-farqi al-mmubin baina al-thlaq wa alyamin

d. Risalah li sujud al-sahwi

e. Al-'ubudiyah

C. Tasawwuf ${ }^{129}$

a. Al-furqôn baina auliyâ al-Rahman wa auliyâ al-syaithôn

b. Abthalu Wahdah al-Wujud

c. Al-Tawasul wa al-Wasilah

d. Risalah fi al-salma wa al-raqsi

e. kitab al-taubah

f. Al-'ubudiyyah

g. Darajat al-yaqin

D. Ushulu al din wa al ra' du 'ala al mutakallimin ${ }^{130}$

a. Risalah fi ushulu al-din

b. Kitab al-iman

c. Al-Furqôn baina al-haq wa al-bâthil

d. Syarah al-'aqidah al-ashfihiniyah

e. Jawabu ahli al-ilmi wa al-iman

f. Risalah fi al-ihtijaj bi al-qadr

g. Shihah ushulu al-mazhab

h. Majmu' altauhid

${ }^{129}$ Syaikh Said Abdul Azhim, Ibnu Taimiyah Pembaharuan Salafi dan Dakwah Reformasi, diterjemahkan oleh Faisal Saleh, Penerbit Pusstaka al-Kautsar, Jakarta, Tahun 2005, hal. 259 (D) ${ }^{130}$ Ibid. 
E. Al Ra'du 'Ala Ashab al Milal

a. Al-Jawab al-shahih liman badala dina al-haq

b. Al-ra'du 'ala al-nashara

c. Takhjil ahli al-in

d. Al risalah al-qabarshiyah ${ }^{131}$

F. Al fasafah al mantiq

a. Naqdhu al mantiq

b. Al-Raddu 'Ala al Mantiqiyin

c. Al-risalah al-'arsyiah

d. Kitab nubuwat

G. Akhlak wa al siyasah wa al-ijtima'

a. Al-hisbah fi al-Islam

b. Al siyasah al-syar'iyyah fi Ishlâhi al-ra'yi wa al-ra'iyyah

c. Al wasiyah al-jami' ah li khairi al-dunia wa al-akhirah

d. Al mazhalim al-Musytarikah

e. Al amru bi alma'ruf al nahyu 'an al-munkar

f. Amrâdhu qulub wa syifâ'uhâ

H. Ilmu al-hadits wa al-mustalahah

a. Kitab fi 'ilmi al-hadits

b. Minhaj Sunnah Nabawiyyah. ${ }^{132}$

Disamping buku-buku yang ditulis Ibnu Taimiyyah diatas juga ada karyanya yang mashur antara lain : al-fatawa al-kubra sebanyak lima jilid, al-

${ }^{131}$ Said Abdu al'Azhim, Ibnu Taimiyah Pembaharuan Salafi dan Dakwah Reformasi, diterjemahkan oleh Faisal Saleh, Penerbit Pusstaka al-Kautsar, Jakarta, Tahun 2005, hal. 259

${ }^{132}$ Syaikh Said Abdul Azhim, Ibnu Taimiyah Pembaharuan Salafi dan Dakwah Reformasi, Terj, Faisal Saleh, (Jakarta: Pusstaka AL-Kautsar, 2005), hal. 259 
shafadiyah sebanyak dua jilid, al-Istiqômah sebanyak dua jilid, al-fatawa alhämawiyyah al-kubra, al-tuhfah al-'Iraqiyyah fi a'mar al-qalbiyah, al-hasanah wa al-Sayyiah, dar'u ta'arudh al-aql wa al-naql, sebanyak sembilan jilid. ${ }^{133}$

Menurut Qamaruddin Khan bahwa karya Ibnu Taimiyah yang masih dijumpai sebanyak 187 buah judul, dari jumlah tersebut dapat diklasifikasikan menjadi tujuh bersifat umum, empat buah judul merupakan karya besar dan 177 buah judul merupakan karya kecil. Dari 177 buah judul dapat diklasifikasikan co dalam topik-topik pembahasan sebagai berikut : 9 judul masalah Qur'an dan tafsir, 13 judul masalah hadits, 48 judul masalah dokma, 6 judul masalah polemikpolemik menentang para sufi, 6 judul masalah polemik-polemik menentang konsep-konsep zimmah, 8 buah masalah yang menentang sekte-sekte Islam, 17 judul masalah fiqh dan ushul fiqh dan 23 judul buku tanpa diklasifikasikan ${ }^{134}$.

\section{6) Dasar Metode Istimbath Ibnu Taimiyah}

Ibnu Taimiyah selalu disebut sebagai ulama yang tidak terikat pada salah satu mazhab, akan tetapi ia tetap digolongkan kepada ulama yang berjalan diatas mazhab Imam Ahmad bin Hanbal, yang mashur dengan sebutan Mazhab Hanbali. के

Sedangkan setiap mazhab memiliki kerangka umum dalam penggalian hukum dari dalil-dalil syar'i. Istilah ini dikenal dengan nama istinbath hukum. Secara bahasa kata istinbath berasal dari bahasa Arab yaitu “ " " yang berarti mengeluarkan, melahirkan, menggali dan lainnya.

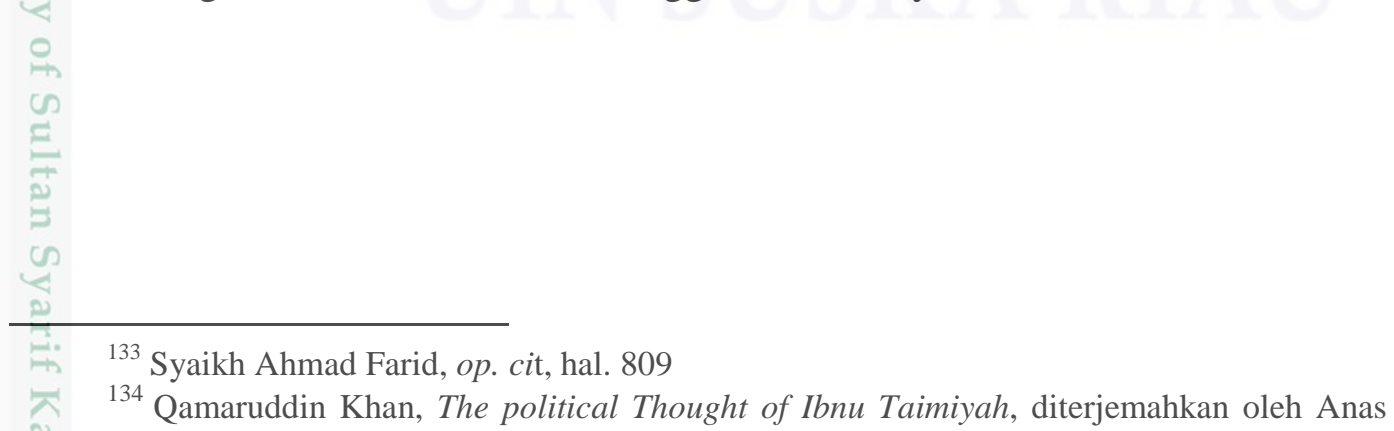
Mahyuddin, Penerbit Pustaka, Bandung Tahun 1983, hal. 315-340 
Setiap ahli fiqh dari keempat imam madzhab yang sudah kita kenal, ${ }^{135}$ masing-masing mempunyai dasar-dasar pokok (ush 1-ush 1) sebagai sandaran dan tempat kembalinya di dalam pengambilan hukum. Ibnu Taimiyah bukanlah imam madzhab yang mempunyai dasar-dasar pokok secara tersendiri, sebagaimana keempat imam madzhab: Hanafi, M liki, Syafi‘i dan Hambali. Hukum-hukum fiqh yang Ibnu Taimiyah istinbâthkan bersandarkan kepada ush 1 fiqh imam madzhabnya, yaitu imam Ahmad bin Hambali. ${ }^{136}$

$\frac{10}{c}$

Salah satu murid yang paling terkenal yaitu Ibnu Qayyim al-Jauziah (wafat tahun $751 \mathrm{H}$ ) menyebutkan bahwa dasar-dasar pokok (ush 1) Ahmad bin Hanbal adalah nash dari al-Quran dan al-Hadis. ${ }^{137}$ Jika dalil-dalil untuk suatu masalah sudah didapatkan dalam kedua sumber diatas, imam Ahmad tak melihat dalil-dalil lain yang bertentangan dengannya, meskipun datangnya dari para sahabat

Jika nash tidak ada, maka dia menyandarkan diri pada dalil fatwa-fatwa sahabat, jika pendapat itu tak ada pertentangan, tanpa ragu-ragu lagi pendapat itu diambil tanpa memperhatikan pendapat-pendapat yang lain. Namun, hal ini tidak disebut ijmâ', hanya disebuts sebagai tawarru', langkah ini diambil karena tidak

${ }^{135}$ Empat Imam mazhab: Nu'man bin Tsabit bin Zuta bin Mahan at-Taymi, lebih dikenal dengan nama Abû anîfah, (lahir di Kufah, Irak pada 80 H / 699 M meninggal di Baghdad, Irak, 148 H / 767 M) merupakan pendiri dari Madzhab Hanafi. Mālik ibn Anas bin Mālik bin Āmr alAssbahi atau Mâlik bin Anas (lengkapnya: Mālik bin Anas bin Mâlik bin Āmr, al-Imam, Abû `Abd Allah al-Humyari al-Asbahi al-Madani), lahir di (Madinah pada tahun 714 (93 H), dan meninggal pada tahun $800(179 \mathrm{H})$ ). Ia adalah pakar ilmu fikih dan hadis, serta pendiri Mazhab Mâliki. Abû Abdullâh Muhammad bin Idrîs al-Shafi i atau Muhammad bin Idris al-Syâfi'i yang akrab dipanggil Imam Syafi ‘i (Gaza, Palestina, 150 H / 767 Fusthat, Mesir 204H / 819M) adalah seorang mufti besar Sunni Islam dan juga pendiri mazhab Syafi ‘i. Abû Abdillâh Ahmad bin Muhammad bin Hanbal bin Hilal bin Asad bin Idris bin Abdullâh bin Hayyan bin Abdullâh bin Anas bin Auf bin Qasith bin Mazin bin Syaiban bin Dzuhl bin Tsa labah adz-Dzuhli asy-Syaibaniy sering dikenal dengan Imam Ahmad bin Hanbal Asy Syaibani, dilahirkan di Baghdad dan tumbuh besar di sana hingga meninggal pada bulan Rabiul Awal. Beliau memiliki pengalaman perjalanan mencari ilmu di pusat-pusat ilmu, seperti Kufah, Bashrah, Mekah, Madinah, Yaman, Syam

${ }^{136}$ Ahmadi Thaha, Ibnu Taimiyah. hal. 86. Penerbit PT. Bina Ilmu, Surabaya Tahun 1982

${ }^{137}$ Ibnu Qayyim al-Jawziyyah, I'lâm al-Muwâqi'în, Penerbit Dâru al-Fikri, Bairut. Tanpa tahun terbitan, hal. 24. 
diketahui ada pendapat yang bertentangan dengan fatwa sahabat, jika ditemukan banyak pendapat para sahabat mengenai satu masalah, maka yang diambil adalah pendapat yang paling dekat kebenarannya terhadap nash. ${ }^{138}$

Dalil yang diambil dari hadis mursal atau hadis lemah (dha'if) dikuatkan oleh qiyâs, selama tidak ada atsar lain yang menguatkannya. Pendapat sahabat atău ijmâ' yang bertentangan, kemudian dapat disandarkan kepada qiyâs, jika keempat ush 1 di atas tidak ada, maka qiyâs ini harus digunakan untuk keadaan dan situasi darurat. Demikian Imam Ahmad bin Hambal dalam dasar-dasar pokoknya, begitu pula Ibnu Taimiyah, meskipun pada beberapa bagian ada perbedaan dari pandangan yang khas, penambahan atau perincian yang lebih jelas darinya. Ibnu Taimiyah tidak pernah menyebutkan bahwa langkah-langkah yang dilalui untuk pengambilan hukum-hukum syar'i dalam ush 1 fiqh adalah ijmâ' kaum Muslimin terhadap al-Quran dan al-Sunnah dengan berbagai cara, berupa: ijmâ', qiyâs, istis $\hat{a} b^{139}$

Kita dapat mengetahui sebenarnya dalil-dalil hukum yang digunakan oleh Ibnu Taimiyah dalam mewarnai dunia fiqh dan hukum-hukum syar'i. Ibnu Taimiyah telah menyebutkan dasar-dasar yang dibangun oleh istinbâth atasnya pâda salah satu risalahnya yang dinamakan turuk al-ahkâm al-syariâh, maka dia mengemukakan bahwa Thuruk al-ahkâm al-syariâh itu adalah dengan ijmâ' kaum muslim atas penafsiran al-Quran dimana tidak ada satu pemimpinpun yang

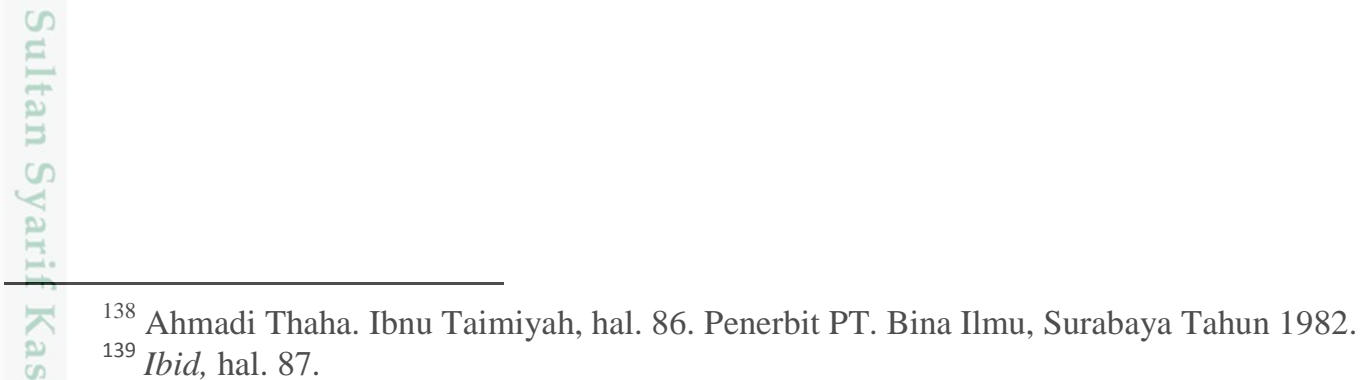

${ }^{138}$ Ahmadi Thaha. Ibnu Taimiyah, hal. 86. Penerbit PT. Bina Ilmu, Surabaya Tahun 1982. 
berselisih dalam hal itu, sebagaimana peselisihan kelompok orang-orang yang sesat dalam pengambilan dalil-dalil atas sebagian masalah-masalah keyakinan. ${ }^{140}$

\section{7) Sanjugan Dan Pujian Ulama Kepada Ibnu Taimiyyah}

Sanjungan dan pujian para ulama kepada Ibnu Taimiyyah sangat banyak

dan bercorak ragam ungkapan mereka kepada Ibnu Taimiyyah, diantaranya:

Al-hâfizh Abu al-Fath al-Ya'muri al-Syâfi'i wafat pada tahun $734 \mathrm{H}^{141}$ ia berkata :

(.)

$\subseteq$

"Beliau (Ibnu Taimiyyah) menguasai hadits-hadits dan atsar-atsar dengan hafalan, jika beliau berbicara tentang tafsir maka beliau adalah pembawa bendera ilmu tafsir, atau jika beliau berfatwa dalam fikih maka beliau tahu puncak ilmu fikih, atau tatkala ia menyebutkan hadits maka beliau adalah pemiliki ilmu hadits dan periwayatannya, atau tatkala menyebutkan tentang ilmu aliran dan agama maka tidak dilihat ada orang yang lebih luas ilmunya daripada beliau dan tidak ada yang lebih tinggi pengetahuannya. Beliau unggul pada seluruh cabang ilmu di atas orang-orang yang sebangsa beliau. Dan orang yang pernah melihatnya tidak $\exists$ pernah melihat orang lain yang semisalnya, dan dia sendiri tidak pernah melihat orang yang seperti dirinya" 142

${ }^{140}$ Muhammad Ab Zahrah, Ibnu Taimiyah hal. 379, Penerbit Dâru al-Fikir al-Arabi, Mesir, Tahun $1952 \mathrm{M}$

${ }^{141}$ Lihat al-Duror al-Kâminah fi a'yan al-mi'ah al-tsâminah, (4/330) oleh Ahmad bin Ali bin Muhammad bin Hajar al-Asqolany Syihabu al-Din. Penerbit Dâ'irah al-Ma'ârif alUtsmâniyyah-Haidar Âbâd, Tahun 1349H

${ }^{142}$ Lihat Ajwibah Ibni Sayyid al-Nâs Al-Ya'muri 'an su'âlât Ibni 'Abîk al-Dimyathi, 2/221, ditahqiq oleh DR Muhammad Ar-Rowandi, sebagaimana dinukilkan dalam Al-Jâmi' li Syarhi Syaikh al-Islâm, hal 188. 
Abu al-Hajjâj Yusuf bin Abdi al-Rahmân al-Mizziy al-Syâfi'i (salah satu Imam Al-Jarh wa al-Ta'dîl, penulis kitab Tahdzîbu al-Kamâl, beliau wafat $742 \mathrm{H}$ ) ia berkata :

\section{ia berkata:}

$\underset{+}{+}$

“Aku tidak pernah melihat yang seperti beliau (IbnuTaimiyyah), dan dia sendiri tidak pernah melihat orang yang semisalnya, dan aku tidak pernah melihat sērangpun lebih berilmu tentang al-Qur'an dan sunnah Rasulullah dan lebih $(2$ menjalankan Al-Qur'an As-Sunnah dari pada dia" 143

Kamâlu al-Din Abu al-Ma'âli Muhammad bin Ali al-Zamlakâni al-Syâfi'i (wafat $728 \mathrm{H}$ ), beliau memuji Ibnu Taimiyyah dengan mengatakan :

"Jika Ibnu Taimiyyah ditanya tentang salah satu cabang ilmu maka orang yang melihat dan mendengar (jawabannya) menyangka bahwa Ibnu Taimiyyah tidak mengetahui cabang ilmu yang lain” (Syadzarôt al-Dzahab 8/144), maksud beliau yaitu karena terlalu hebatnya Ibnu Taimiyyah dalam bidang ilmu tersebut, sehingga seakan-akan Ibnu Taimiyyah menghabiskan umurnya untuk mempelajari c)

satu bidang ilmu saja dan tidak mempelajari bidang ilmu-ilmu yang lain. Akan tetapi ternyata kehebatan ini berlaku pada seluruh bidang ilmu.

Al-Zamlakâni memuji Ibnu Taimiyyah dalam syairnya :

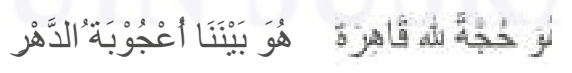

"Dia adalah hujjah milik Allah yang menguasai..dia diantara kita adalah keajaiban zaman"

${ }^{143}$ Lihat Tobaqôt Ulamâ al-Hadîts, (4/283), oleh Muhammad bin Ahmad bin Abdu al-Hâdy al-Dimasqy al-Shalihy Abu Abdillah, Penerbit Muassasah al-Risalah, Tahun 1417H/1996M 
Imam Ibnu Katsiir al-Syâfii menyebutkan bahwasanya al-Zamlakâni memuji Ibnu Taimiyyah dengan syair ini padahal saat itu umur Ibnu Taimiyyah sekitar 30 tahun $^{144}$<smiles>[CH-]1CC1</smiles>

Abu Hayyân al-Andalusi al-Nahwi al-Syâfi'i, Penulis kitab tafsir Al-Bahr at-Muhîth, beliau bermadzhab Maliki kemudian berpindah ke madzhab al-Syafii dān mengarang kitab al-Wahhâj Fi Ikhtihôr al-Minhâj li-Al-Nawawy, wafat tahun (2) $745 \mathrm{H}^{145}$ ia berkata ;

元

"Kedua mataku tidak pernah melihat orang yang semisal Ibnu Taimiyyah", lalu beliau memuji Ibnu Taimiyyah dalam untaian syairnya, ia berkata :

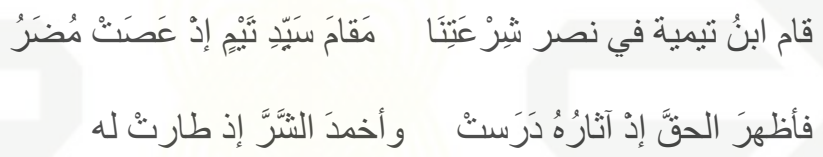

“Tegaklah Ibnu Taimiyyah dalam memperjuangkan syari'at kita...

Sebagaimana Pemimpin Kabilah Taimi (yaitu Abu Bakar As-Shiddiq) tatkala kabilah Mudhor membangkang (menjadi murtad)

Maka Ibnu Taimiyyahpun menampakan kebenaran tatkala atsar dari kebenaran telah lenyap... Dan iapun memadamkan keburukan setelah keburukan merajalela"

Al-Dzahabi al-Syâfii, beliau berkata ;

“Kalau aku bersumpah diantara hajar aswad dan maqom Ibrahim maka aku sungguh akan bersumpah : Aku tidak pernah melihat dengan dua mataku ini orang क ב

${ }^{144}$ Lihat Al-Bidâyah wa al-Nihâyah (18/298) oleh Ismail bin Umar al-Quraisyi bin Katsir al-Bashri al-Dimasyqi Imaduddin Abu al-Fida al-Hafizh al-Muhaddits al-Syafi'i, Penerbit Dâru alMa'ârif Bairut, Tahun 1410H/1990M

${ }^{145}$ Lihat Muqoddimah Tafsîr al-Bahr al-Muhîth, (1/57), Oleh Muhammad bin Yusuf bin Ali bin Yusuf bin Hayyân, dikenal dengan Abu Hayyân Atsîru al-Din, Penerbit Daru al-Kutub alalamiyyah Tahun 1413H/1993M 
yang semisal Ibnu Taimiyyah, dan diapun tidak pernah melihat orang yang semisal dirinya" 146

Ibnu Daqîq al-'Îd al-Syafi'i, beliau pernah ditanya tentang Ibnu Taimiyyah setelah bertemu dengan Ibnu Taimiyyah, maka beliau berkata :

3

"Aku telah melihat seorang yang seluruh ilmu berada di hadapan kedua matanya, ia mengambil apa yang dia sukai dari ilmu-ilmu tersebut dan $\infty$ meninggalkan apa yang ia sukai", 147

(a)

'Imâdu al-Dîn Ahmad bin Ibrahim, Syaikh al-Hazzamiyah al-Washithy alSyâfi'i (wafat 711 H), beliau berkata :

"Demi Allah kemudian demi Allah kemudian demi Allah tidak pernah terlihat dibawah langit ini yang seperti guru kalian Ibnu Taimiyyah dari sisi ilmu, amal, kondisi, akhlak, itiibaa', kedermawanan, kebijaksanaan, dan penegakan terhadap hak Allah Ta'âlâ tatkala dilanggar keharaman. Beliau adalah orang paling benar aqidahnya dan yang paling benar ilmu dan tekadnya, dan yang paling semangat dan paling cepat dalam membela kebenaran dan menegakkannya, dan orang yang tangannya paling pemurah, dan yang paling sempurna ittiba'nya (keteladanannya) kepada Nabi shallallahu 'alaihi wa sallam. Kami tidak pernah melihat di zaman kami ini seseorang yang nampak kenabian muhammadiah serta sunnah-sunnahnya dari perkataan dan perbuatannya kecuali orang ini (Ibnu Q

${ }^{146}$ Lihat al-Dzaylu 'Alâ Tobaqôti al-Hanâbilah (2/390), Oleh Abdu al-Rahman bin Ahmad bin Rajab al-Hambaly, Ditahqiq oleh Abdu al-Rahman bin Sualiman al-Utsaimin, Tahun $1425 \mathrm{H} / 2005 \mathrm{M}$

${ }^{147}$ Lihat Syadzarôtu al-Dzahabi Fi Akhbâri Man Zahab (8/146) Oleh Abdu al-Hayyi bin Ahmad bin Muhammad Ibnu al-'Imad al-'Ikry al-Hambaly Abu al-Falâh, Ditahqiq oleh Abdu alQâdir al-Arnaûth dan Mahmud al-Arnaûth, Penerbit Dâru Ibni Katsîr, Tahun 1406H/1986M 
Taimiyyah), dan hati yang bersih mempersaksikan bahwasanya ini adalah ittibaa' yā̄ng sesungguhnya" 148

Abdullah bin Hamid al-Syâfi'i, beliau pernah menulis kepada Abdullah bīn Rusyaiq (juru tulis Ibnu Taimiyyah/semacam sekertaris), ia berkata :

"Dan sebelum saya menemukan pembahasan-pembahasan Imam Dunia (Íbnu Taimiyyah) rahimahullah, saya telah menelaah kitab-kitab para penulis terdahulu, dan aku telah melihat perkataan para mutaakhirin dari kalangan ahli filsafat, maka aku mendapatinya terdapat kebatilan-kebatilan dan keraguankeraguan yang tidak pantas untuk terbetik di hati seorang muslim yang lemah apalagi seorang yang agamanya kuat. Sungguh meletihkan dan menyedihkan hatiku tatkala aku melihat orang-orang besar bisa terbawa ke pemikiran-pemikiran yang lemah dan rendah yang pemeluk umat ini tidak akan meyakini kebenarannya. Akupun memeriksa sunnah yang murni di buku-buku para ahli filsafat pengikut madzhab Imam Ahmad secara khusus karena mereka tersohor dengan keteguhan mereka memegang perkataan-perkataan Imam mereka (Imam क

Ahmad) dalam masalah pokok-pokok aqidah, akan tetapi aku tidak mendapatkan dari mereka apa yang mencukupi. Aku melihat mereka kontradikisi tatkala mereka menetapkan landasan-landasan yang ternyata bertentangan dengan apa yang mereka yakini. Atau mereka meyakini perkara yang bertentangan dengan konsekuensi dari dalil-dalil mereka. Jika aku mengumpulkan antara pendapatpendapat Mu'tzilah, 'Asya'iroh, dan Hanabilah Baghdad, serta Karomiyahnya di Khurosaan maka aku melihat bahwasanya ijmâk (consensus) para ahli filsafat -

${ }^{148}$ Ibid. $8 / 144$ 
dalam satu permasalahan bertentangan dengan apa yang ditunjukkan oleh dalil akal dan naql (al-Qur'an dan al-Sunnah), maka hal ini membuat aku tidak suka dan menjadikanku bersedih dengan kesedihan yang tidak mengetahui hakekat kesedihanku kecuali Allah. Hingga akupun menderita tatkala menghadapi perkara ini dengan penderitaan yang sangat berat, yang aku tidak mampu untuk menjelaskan sedikit penderitaanku itu. ${ }^{149}$

Akupun bersandar kepada Allah Ta'âlâ dan aku merendah kepada-Nya, lalu aku berlari ke lahiriahnya nas-nas dan aku menemukan pemikiran-pemikiran yang berbeda-beda dan demikian pula takwilan-takwilan yang dibuat-buat, maka fitroh ini tidak mau menerimanya. Lalu fitrohku bergantung kepada kebenaran yang jelas dalam pokok-pokok permasalahan, akan tetapi aku tidak berani terangterangan untuk berpendapat dan menancapkan aqidahku diatasnya karena aku tidak menemukan adanya atsar dari para imam dan para salaf terdahulu. Hingga akhirnya Allah mentaqdirkan aku untuk menemukan kitab-kitab karya Imam Ibnu Taimiyyah rahimahullah menjelang wafatnya beliau. Maka aku mendapatkan di (1) dalamnya sesuatu yang menakjubkanku dimana fitrohku sepakat dengan apa yang terdapat di dalamnya, serta penyandaran kebenaran kepada para imam sunnah dan para salaf, disertai dengan keserasian antara akal dan dalil. Maka akupun terpaku karena sangat senang dengan kebenaran, dan gembira dengan ditemukannya apa yang aku cari-cari yang jika hilang maka tidak ada gantinya. Maka jadilah kecintaanku kepada Ibnu Taimiyyah rahimahullah menjadi sesuatu yang harus,

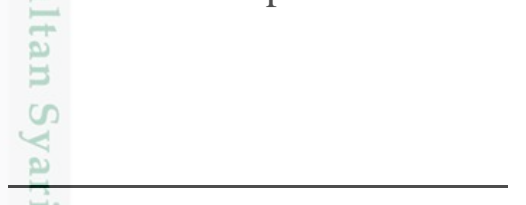

${ }^{149}$ Lihat Al-'Uqûd al-Durriyah Min Manaqib Syaikh al-Islam Ibni Taimiyyah, hal. 307 Oleh Ibnu 'Abdi al-Hâdy al-Hanbaly Syamsu al-Din Abu Abdillah Muhammad bin Ahmad alMaqdisy, ditahqiq oleh Thola' at bin Fu'âd al-Halwâny, Tahun 1422H/2002M 
yang aku tidak mampu untuk mengungkapkan kecintaanku kepadanya meskipun hānya sedikit, walaupun aku sudah berusaha dengan sebaik-baiknya" 150

\section{Ibnu Taimiyyah berlaqabkan "Syaikh al-Islam"}

Adapun tentang kelayakan Ibnu Taimiyah untuk berlaqab dengan sebutan "Syaikh al-Islam”, maka hal ini di jawab oleh para Hafidz! Seperti As-Suyuthi dan Ibnu Rajab, demikian juga Al-Sya'rani, kenapa mereka melaqabkan beliau dengan laqab seperti hal tersebut!

Al-Suyuthi tentang Ibnu Taimiyah "Syaikhul Islam, seorang hafidz yang faqih, mujtahid, mufassir ulung, Syaikh al-Islam, manusia langka dimasanya, alim lagi zuhud”. 151

Al-Zubaidi pemilik kitab Tâjul 'Arûs dan Ittihâf al-Sâdah, dia menjuluki Ibnu Taimiyyah dengan sebutan Syaikh al-Islam dan ia memuji-memujinya serta berhujjah dengan dengan perkataan-perkataannya berulang kali pada kitabnya. Setelah menyifati beliau dengan Syaikh al-Islam dan menukil perkataan agung dari beliau tentang ushul al-Qur'an dia berkata: "Selesai ikhtisar dari perkataan Ibnu Taimiyah yang merupakan perkataan yang sangat berharga sekali”. ${ }^{152}$

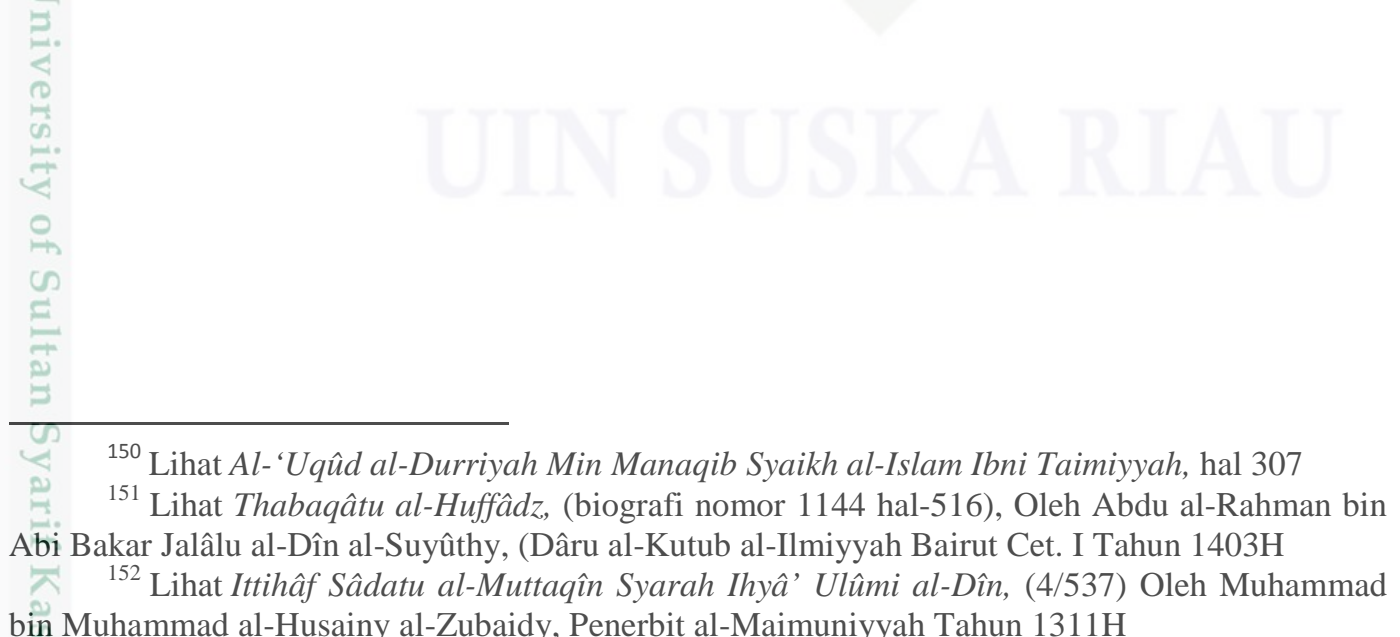
bin Muhammad al-Husainy al-Zubaidy, Penerbit al-Maimuniyyah Tahun $1311 \mathrm{H}$ 
Al-Subki, ia sangat berbangga dengan Abu al-Hajjâj Al Mizzi yang hanya menulis laqab Syaikh al-Islam kepada dua orang,: yaitu kepada ayahnya (AlSubki) Taqiyuddin As Subki dan kepada Taqiyuddin Ibnu Taimiyah. ${ }^{153}$

Al-Ala'i telah Mengakui bahwa Al Mizzi hanya menetapkan Lafadz Syaikhul Islam kepada Taqiyuddin As Subki dan Taqiyuddin Ibnu Taimiyah ${ }^{154}$

As Sya'rani juga mensifatkan beliau dengan sebutan Syaikh al-Islam. ${ }^{155}$

Syaikh Syamsuddin Muhammad bin Shofiyuddin yang berkata: "Kalau Ibnu Taimiyah bukan Syaikhul Islam, maka siapa”?

Disebutkan oleh Qadhi al-Qudhat Ibnu al-Hariri al-Hanafi, beliau ini mendapat penganiayaan disebabkan sikapnya yang adilnya terhadap Ibnu Taimiyyah ${ }^{156}$

Ibnu Thulun juga mensifati Ibnu Taimiyyah sebagai " Syaikh al-Islam yang bertaqwa" dan bersaksi bahwasanya beliau adalah seorang yang amat alim di zamannya.

Ibnu Katsiir (penulis kitab Tafsiir Al-Qur’aan al-‘Adziim). Beliau berkata : "Telah ditulis banyak buku tentang biografi beliau, dan sejumlah dari kalangan . orang-orang yang mulia dan selain mereka juga menulis biografi beliau. Dan kami क akan menuliskan biografi singkat tentang manaqib beliau, keutamaan-keutamaan $\stackrel{\circ}{\circ}$

$\underline{\square}$

${ }^{153}$ Lihat juga Al-Dzailu 'alâ Thabaqâti al-Hanâbilah, (2/387)

${ }^{154}$ Lihat Naqdu al-Thâlib li-Zaghli al-Munâshibi, hal 45 Oleh Muhammad bin Thûlûn alShôlihy Syamsu al-Din al-Dimasyqi, Terbit Tahun 1412H/1992M

${ }^{155}$ Lihat Lathoifu al-Minan wal Akhlaq fi al-Tahdits bi Ni'matillâhi 'alâ al-Ithlâq, hal. 552, Oleh Abdu al-Wahhâb al-Sya'râny, Penerbit Maktabah al-Tashawwuf-Maktabah al-Sya'râny Dâru al-Taqwâ Tahun 1439H

${ }^{156}$ Lihat Al-Duroru al-Kâminah, (1/147), Lihat Al-Bidayah wa al-Nihayah, Ibnu katsir (14/142) 
beliau, keberanian, kedermawanan, nasehat beliau, zuhudnya beliau, ibadah betiau, ilmu beliau yang banyak..." 157

\section{8) Sejarah Wafatnya Ibnu Taimiyyah}

Sesungguhnya di antara tanda kebaikan orang shalih dan diterimanya dia di tengah-tengah kaum muslimin adalah : orang-orang merasakan kehilangannya tatkala dia itu meninggal dunia. Oleh karena itu, para ulama salaf menilai banyaknya manusia yang mensholatkan seseorang maka itu merupakan tanda kébaikan dan diterimanya orang tersebut (disisi Allah). Maka oleh karena itu, Imam Ahmad Bi Hambal -rahimahullah- pernah mengatakan: "Katakan kepada Ahlul Bid'ah, perbedaan antara kami dan kalian adalah pada hari kematian”, yaitu orang-orang akan merasakan kehilangan Imam Ahlusunnah, apabila imam tersebut meninggal dunia, maka akan terlihat banyaknya orang yang mengiringi jenazahnya ke pemakaman. Sungguh realita telah menunjukkan hal itu, yaitu belum pernah ada terdengar banyaknya orang yang mengiringi jenazah seseorang seperti terjadinya kematian pada dua imam (yang sama-sama bernama Ahmad, pent) yaitu Imam Ahmad bin Hambal dan Ahmad bin Taimiyyah ketika keduanya meninggal. Begitu banyak orang yang mengiringi ke pemakaman dan mereka keluar bersama jenazah keduanya serta merekapunn mensholatkan keduanya. Ini bukanlah suatu yang aneh karena kaum muslimin adalah saksi Allah di bumi ini.

Demikianlah Syekh al-Islam Ibnu Taimiyyah rahimahullah wafat, dalam keadaan beliau terpenjara di penjara al Qol'ah, Damaskus, pada malam Senin, 20 $\underline{E}$

Dzzulqa'dah 728 Hijriyah. Seluruh penduduk Damaskus dan sekitarnya merayap untuk mensolatkan dan mengiringi jenazah beliau ke pemakaman. Berbagai

${ }^{157}$ Lihat Al-Bidâyah wa Al-Nihâyah, (18/302) 
referensi yang menyebutkan kematian beliau sepakat bahwa yang menghadiri pemakaman beliau adalah jumlah yang sangat besar sekali yang tidak bisa dibayangkan jumlahnya ${ }^{158}$

C. PENELITIAN YANG RELEVAN DENGAN JUDUL TESIS

Setelah penulis melakukan berbagai usaha untuk mencari tulisan atau karya ilmiyyah yang memiliki relevansi dengan judul tesis penulis, maka penulis menemukan beberapa karya ilmiyyah diantaranya adalah:

1. Pemimpin Non-Muslim Dalam Persfektif Ibnu Taimiyah oleh Abu Tholib Khalik Mahasiswa Fakultas Ushuluddin Institut Agama Islam Negeri Raden Intan Lampung, yang diterbitkan oleh ANALISIS: Jurnal Studi Keislaman, Volume 14, Nomor 1, Juni 2014

Penulis Jurnal ini yaitu saudara Abu Tholib Khalik, termasuk orang yang mengklaim bahwa Ibnu Taimiyyah membolehkan non Muslim menjadi pemimpin atas kaum muslimin, yang mana penulis telah membuat suatu kesimpulan pada penutup tulisannya di jurnal ini dengan mengatakan: Ibnu Taimiyah telah mengeluarkan statement yang sangat "berani”, yakni "lebih baik dipimpin oleh pemimpin kafir yang adil, daripada dipimpin oleh pemimpin muslim yang dzalim”.

Dari hasil penelitian yang penulis lakukan maka penulis tidak menemukan ungkapan yang dinukilkan oleh saudara Abu Tholib Khalik, ini adalah nukilan yang sangat "ngawur" karena dasarnya tidak ilmiah, yang ada justru Ibnu Taimiyyah menyatakan kebalikkannya sebagaimana yang

${ }^{158}$ Lihat Iqtidha' Shirathil Mustaqim Li Mukhalafatil Ashabil Jahim. Tahqiq Dr. Nashir bin Abdul Karim Al 'Aql. Sumber: Assunnah-qatar.com 
penulis nukilkan dari kitab Ibnu Taimiyyah sendiri yaitu beliau menyatakan :

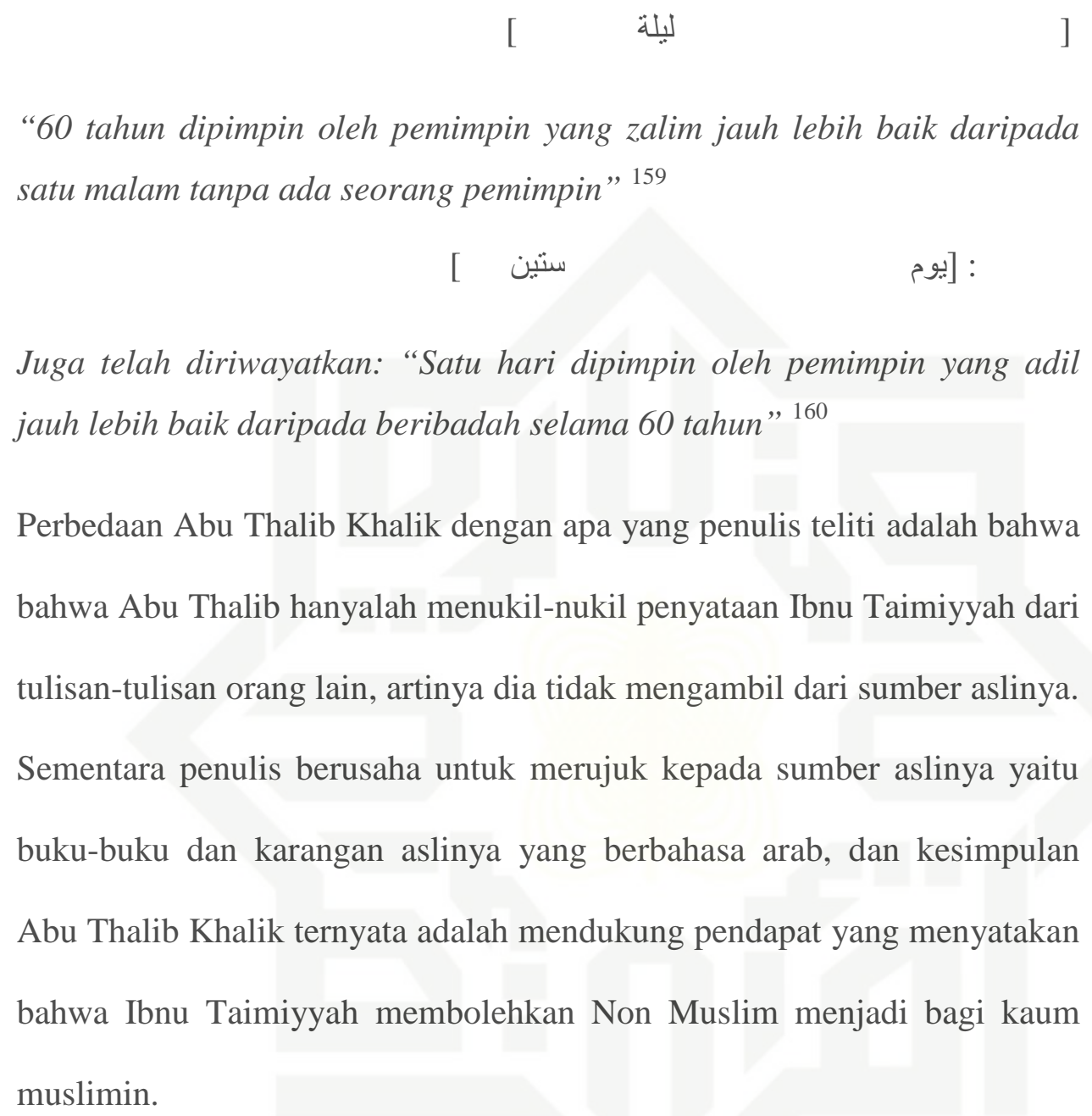

Juga telah diriwayatkan: "Satu hari dipimpin oleh pemimpin yang adil jauh lebih baik daripada beribadah selama 60 tahun" 160

Perbedaan Abu Thalib Khalik dengan apa yang penulis teliti adalah bahwa bahwa Abu Thalib hanyalah menukil-nukil penyataan Ibnu Taimiyyah dari tulisan-tulisan orang lain, artinya dia tidak mengambil dari sumber aslinya. Sementara penulis berusaha untuk merujuk kepada sumber aslinya yaitu buku-buku dan karangan aslinya yang berbahasa arab, dan kesimpulan Abu Thalib Khalik ternyata adalah mendukung pendapat yang menyatakan bahwa Ibnu Taimiyyah membolehkan Non Muslim menjadi bagi kaum muslimin.

2. Tinjauan Hukum Islam Terhadap Pemimpin Non Muslim Dalam Masyarakat Islam, sebuah tulisan yang diangkat oleh Muhammad Galib Iqbal.

Berdasarkan pembahasan dan analisis pada bab-bab sebelumnya, maka dapat diambil kesimpulan sebagai berikut :

159. Ibnu Taimiyyah, al-siyâsah al-syar'iyyah fî islâhi al-râ'iy wa al-ra'iyyah, Hal. 217

160. Ibid. Hal. 217 
Para ulama berbeda pandangan mengenai kepemimpinan Non Muslim di kalangan mayoritas Islam, Pertama kelompok yang melarang secara mutlak memilih pemimpin non muslim karena mereka memiliki kesamaan dalam menafsirkan lafadz awliya" dengan penolong dan pemimpin. Kedua kelompok yang membolehkan adanya pemimpin dari kalangan nonmuslim untuk daerah yang mayoritas muslim karena mereka berpandangan lafadz awliya" tidak lagi sesuai dengan konteks saat ini.

Dalam pespektif hukum Islam bahwa pemimpin itu dalam fiqh siyâsah disebut khalifah al-nabawiyyah artinya pengganti Nabi dalam mengurusi ummat dalam berbagai urusan dunia, agama ataupun negara, oleh karena itu mengangkat non Muslim untuk menangani urusan kaum muslimin adalah tidak akan bisa teralisasi dan terwujud sampai kapapun, maka hukum mengangkatnya berinplikasi kepada keharaman.

Kesimpulan penulis Muhammad Galib Iqbal memiliki kesamaan dengan hasil penelitian yang penulis paparkan yaitu "Tidak boleh seorang Non Muslim menjadi pemimpin bagi kaum muslimin”.

3. Disertasi dari salah seorang mahasiswa Universitas Kairo yang kemudian diterbitkan Dar Al-Akhilla’ Dammam KSA berjudul:

النظرية السياسية عند ابن تيمية بقلم حسن قاناكات

Penulis yaitu Hasan Konakata menyatakan bahwa dari berbagai tulisannya dapat disimpulkan bahwa Ibnu Taimiyyah menetapkan dua syarat umum bagi seorang pemimpin Muslim, yaitu al-quwwah wa al-amânah 
(kekuatan dan amanah). Kesimpulan ini diambil dari pernyataan Ibnu Taimiyyah sendiri di dalam Al-Siyâsah Al-Syar'iyyah (Dar Al-Afaq AlJadidah Beirut, 1998: 15):

Sesungguhnya kepemimpinan itu memliki dua rukun: kekuatan dan amanah, sebagaimana firman Allah Swt., "Sesaungguhnya sebaik-baiknya orang yang kau upah adalah yang kuat lagi amanah. (QS Al-Qashash: 26). Berkata pemimpin Mesir kepada Yusuf, "Sesungguhnya engkau sekarang ini memiliki posisi yang kuat dan terpercaya di sisi kami." (QS Yusuf: 54); Allah Swt. berfirman tentang sifat Jibrir, "Sesungguhnya itu merupakan ucapan utusan yang mulia; yang memiliki kekuatan dan kedudukan yang kuat di sisi Sang Pemilik Arsy; yang taat lagi dapat dipercaya." (QS Al-Takwir: 19-21).

Kesimpulan penulis Hasan Konakata memiliki kesamaan dengan hasil penelitian yang penulis paparkan yaitu "Tidak boleh seorang Non Muslim menjadi pemimpin bagi kaum muslimin".

4. Artikel Berbahasa Arab yang penulisnya adalah Iyhab Kamal Ahmad dengan judul.

$$
\text { المبين على من أجاز و لاية الكافر على المسلمين بقلم إيهاب كمال أحمد }
$$

Penulis artikel ini membantah orang-orang yang membolehkan non Muslim untuk menjadi pemimpin bagi kaum muslimin, penulis membantah mereka dengan menghadirkan argumentasi rabbani yaitu dalildalil yang bersumber dari Al-Qur'an dan As-Sunnah serta Ijma' Ulama. 
Kesimpulan penulis Iyhab Kamal Ahmad memiliki kesamaan dengan hasil penelitian yang penulis paparkan yaitu "Tidak boleh seorang Non Muslim menjadi pemimpin bagi kaum muslimin”.

5. Artikel Berbahasa Arab juga yang penulisnya adalah Abu Islam Hazim Bin 'Ali Khattab dengan judul.

غفر الله القول المبين في منع و لاية الكافر على المسلمين كتبــــه أبو إبــلام

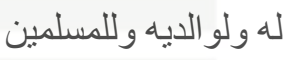

Penulis artikel ini juga membantah orang-orang yang membolehkan non Muslim untuk menjadi pemimpin bagi kaum muslimin, dan juga penulis membantah mereka dengan menghadirkan argumentasi dari dalil-dalil AlQur'an dan As-Sunnah serta Ijma' Ulama.

Kesimpulan bahwa penulis artikel ini memiliki sisi pandangan yang sama dengan hasil penelitian yang penulis paparkan yaitu bantahan terhadap orang-orang yang membolehkan Non Muslim menjadi pemimpin bagi kaum muslimin. 


\section{BAB III}

\section{METODOLOGI PENELITIAN}

\section{Jenis dan Pendekatan Penelitian}

Jenis penelitian ini adalah penelitian kepustakaan (library research) yaitu penelitian yang dilakukan dengan cara mempelajari, menelaah, dan memeriksa bahan-bahan kepustakaan yang memiliki relevansi hukum dengan pokok permasalahan. ${ }^{1}$ Penelitian ini juga disebut penelitian hukum normatif. ${ }^{2}$

Pendekatan yang digunakan dalam penelitian ini adalah pendekatan kualitatif. Pendekatan kualitatif menurut Anslem Straus dan Juliet Corbin adalah penelitian yang temuan-temuannya tidak diperoleh melalui prosedur statistik atau bentuk hitungan lainnya. ${ }^{3}$

\section{B. Sifat Penelitian}

Penelitian ini bersifat deskriptif analitis. Bersifat deskriptif di sini adalah penelitian yang mendeskripsikan permasalahan kepemimpinan non muslim menurut perspektif Syekh Al-Islam Ibnu Taimiyyah dan juga menggambarkan secara menyeluruh dan mendalam tentang permasalahan ini berdasarkan nashnash Al-Qur'an, As-Sunnah, Ijma' dan pendapat-pendapat para ulama Islam lainnya. Dan penelitian ini juga penelitian yang bersifat analitis, yang dimaksud penelitian yang bersifat analitis di sini adalah penelitian yang menganalisis pemikiran-pemikiran Syekh Al-Islam Ibnu Taimiyyah dan juga menganalisis

1 Yayasan Obor Indonesia, Metode Penelitian Kepustakaan, Jakarta: Yayasan Obor Indonesia, 2004, h. 3.

${ }^{2}$ Amiruddin dan Zainal Asikin, Pengantar Metode Penelitian Hukum, Jakarta: Rajawali Pers, 2010, h. 36.

3 Anslem Strauss dan Juliet Corbin, Dasar-Dasar Penelitian Kualitatif, alih bahasa M. Shodiq dan Imam Muttaqien, Yogyakarta: Pustaka Pelajar, 2009, h. 4. 
sumber-sumber hukum dalam syari'at Islam yang terkait dengan permasalahan kepemimpinan non muslim.

\section{Bahan Penggalian Data}

Data yang ada dalam penelitian ini terdiri dari tiga bahan data yaitu pertama data primer, kemudian kedua data skunder, serta ketiga bahan tersier Ketiga bahan data tersebut uraiannya sebagai berikut:

1. Bahan primer adalah data primer yang merupakan sumber data yang diperoleh secara langsung dari sumber aslinya, yaitu buah karya pemikiran Ibnu Taimiyyah yang terdapat dalam kitab-kitabnya secara khusus seperti al-siyâsah al-syar'iyyah fi islâhi al-râ’î wa al-ra'iyyah (و الر اعية السياسة الثرعية في إصلاح الراع), al-siyâsah al-syar'iyyah (السياسة الشرعبة), al-hisbah ( )

2. Bahan sekunder ${ }^{4}$ maksudnya adalah data sekunder yang merupakan sumber data penelitian yang diperoleh peneliti secara langsung ke sumber aslinya atau secara tidak lansung yaitu melalui media perantara (yaitu diperoleh dan dicatat oleh pihak lain). Data sekunder umumnya berupa bukti, catatan atau laporan historis yang telah tersusun dalam arsip (data dokumenter) yang dipublikasikan dan yang tidak dipublikasikan, dan juga referensi-referensi lainnya yang berkaitan dengan pembahasan penelitian seperti kitab-kitab klasik atau buku-buku para ulama baik dari Ibnu Taimiyyah sendiri maupun ulama-ulama yang lainnya, yang berkaitan dengan permasalahan kepemimpinan non muslim atas kaum muslimin seperti Iqtidhô Shirôthô al-Mustaqîm Li-Mukhôlafati Ashâbi at-Jahîm (المستقيم لمخالفة أصحاب الجحيم) oleh Ibnu Taimiyyah, al-Furqôn

${ }^{4}$ Bahan hukum sekunder adalah bahan yang memberikan penjelasan mengenai bahan
hukum primer. Lihat: Amiruddin dan Zainal Asikin, Pengantar Metode Penelitian Hukum, hal. 32 
Baina Awliyâ' al-Rahman Wa-Awliyâ' al-Syaithân (الفرقان بين أولياء الرحمن وأولياء (الثيطان oleh Ibnu Taimiyyah, (الأحكام السلطانية) al-Ahkâm al-Sulthôniyyah (AlMawardi), dan lain-lainnya

3 Bahan tersier ${ }^{5}$ dalam penelitian ini ialah seperti kamus berbahasa Arab, eñsiklopedia, jurnal, artikel yang berkaitan dengan pembahasan tentang permasalahan kepemimpinan non muslim dalam masyarakat Islam.

Data-data tersebut dikumpulkan dengan teknik pentela'ahan, pemahaman, dan penganalisisan terhadap referensi-referensi yang relevan dan berhubungan dengan permasalahan yang akan diteliti khususnya terkait perspektif Ibnu Taimiyyah yang terdapat dalam kitab-kitabnya dan ada kaitannya dengan permasalahan kepemimpinan Non Muslim di tengah masyarakat Islam.

\section{Pengolahan dan Penyajian Data}

Data yang terkumpul disajikan dengan metode deskriptif dan deduktif. Metode deskriptif yaitu menggambarkan objek permasalahan berdasarkan fakta secara sistematis, akurat, dan karakteristik terhadap kajian penelitian. ${ }^{6}$ Menurut Po

Sễrjono metode deskriptif dimaksudkan untuk memberikan data mengenai manusia, keadaan atau gejala-gejala lainnya secara cermat, mendalam, dan teliti. ${ }^{7}$ Metode ini digunakan untuk mendeskripsikan permasalahan kepemimpinan non muslim dalam masyarakat Islam secara apa adanya dan sistematis dari perspektif Ibnu Taimiyyah dalam menyikapi permasalahan kepemimpinan non muslim dalam masyarakat Islam.

\footnotetext{
ค. ${ }^{5}$ Bahan hukum tersier adalah bahan yang memberikan petunjuk maupun penjelasan terhadap bahan hukum primer dan bahan hukum sekunder, seperti kamus (hukum), ensiklopedi,

${ }^{6}$ Saifuddin Azwar, Metode Penelitian, Yogyakarta: Pustaka Pelajar, 2007, hal. 7

${ }^{7}$ Soerjono Soekanto, Pengantar Penelitian Hukum, Jakarta: UI-Press, 1986, hal. 10.
} 
E.

Analisis Data

Metode analisis data yang digunakan dalam penelitian ini adalah metode analisis isi atau content analysis. Metode ini mensyaratkan objektifitas, pendekatan sistematis, dan generalisasi. ${ }^{8}$ Menurut Noendrof sebagaimana dikutip oleh Emzir bahwa: Analisis isi merupakan suatu analisis mendalam yang dapat menggunakan teknik kuantitatif maupun teknik kualitatif terhadap pesan-pesan menggunakan metode ilmiah dan tidak terbatas pada jenis-jenis variabel yang o dapat diukur atau konteks tempat pesan-pesan diciptakan atau disajikan. ${ }^{9}$

Cik Hasan Bisri menjelaskan bahwa content analysis digunakan untuk penelitian yang bersifat normatif dengan menganalisis teks Al-Qur'an dan teks Al-Hadits, ataupun pemikiran para ulama dengan menggunakan kaidah bahasa atau kaidah usul al-fiqh atau kaidah lainnya, serta dapat menganalisis suatu putusan pengadilan atau yurisprudensi dengan menggunakan penafsiran ektensif, teologis, histors-sosiologis, dan gramatikal (literlik). ${ }^{10}$ Metode analysis content dalam penelitian ini digunakan untuk menganalisis pemikiran politik Ibnu Taimiyyah dalam masalah kepemimpinan non muslim atas masyarakat Islam.

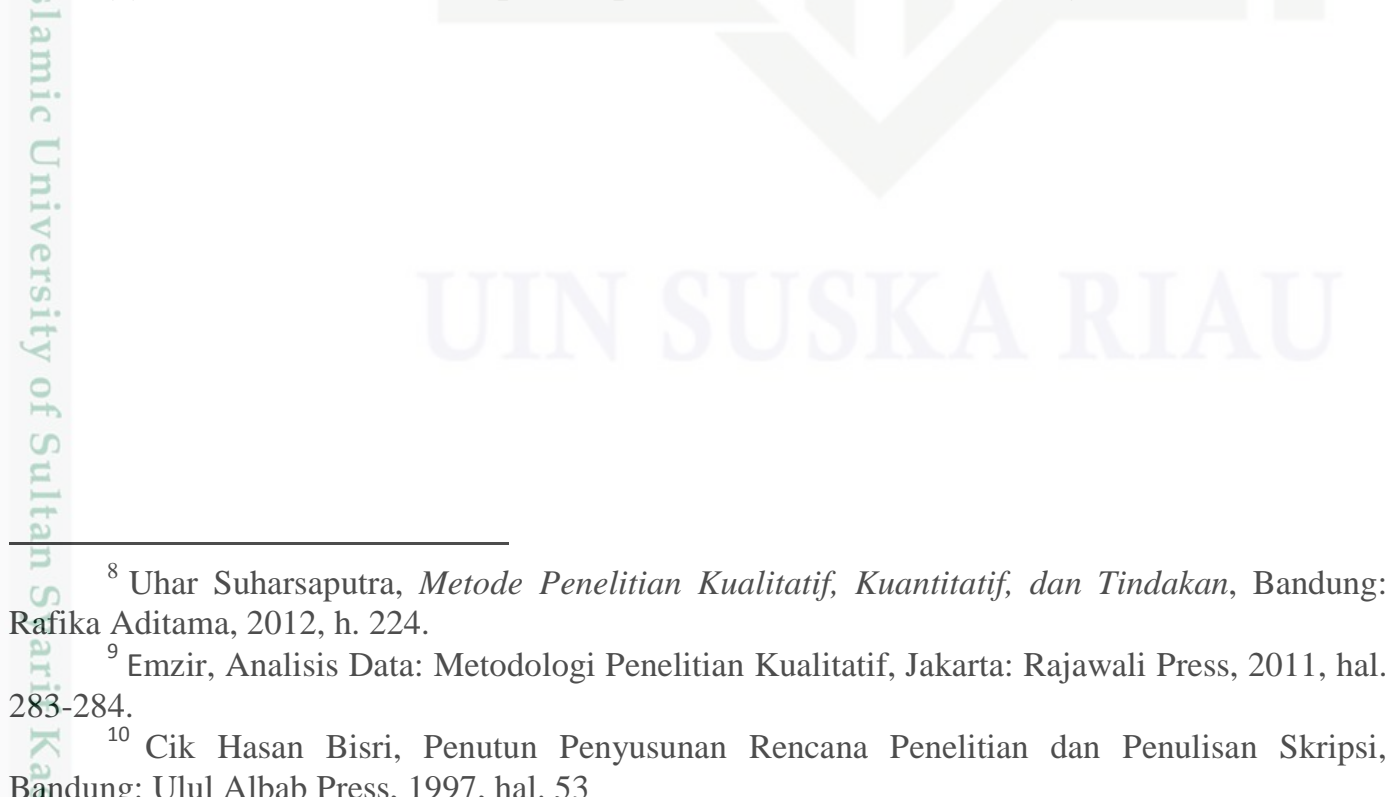
Bandung: Ulul Albab Press, 1997, hal. 53 


\section{BAB V}

\section{PENUTUP}

\section{Kesimpulan}

Berdasarkan pembahasan dan analisis pada bab-bab sebelumnya, maka penulis memberikan kesimpulan sebagai berikut :

Menurut Ibnu Taimiyyah hakikat pemerintahan itu adalah kekuasaan yang memaksa, maka seorang pemimpin itu dapat menuntut kepatuhan dari rakyatnya sendiri, walaupun penguasa tersebut kurang berlaku adil, keadaan seperti itu masih jauh lebih baik daripada rakyat tidak memiliki seorang pemimpin, yang bisa mengakibatkan bubarnya suatu masyarakat, Ibnu Taimiyyah berkata ; "60 tahun dipimpin oleh pemimpin yang jâir (zalim) maka itu jauh lebih baik daripada satu malam tanpa ada seorang pemimpin" Telah dinukilkan sebuah riwayat dari Ibnu Taimiyyah: "Sehari dipimpin oleh pemimpin yang adil maka hal itu jauh lebih baik daripada beribadah selama 60 tahun" Ibnu Taimiyyah mewajibkan adanya sebuah lembaga untuk menegakkan keadilan di bawah kontrol negara. Lembaga itu adalah lembaga Hisbah yang menjadi salah satu ciri khas pemerintahan Islam. Lembaga Hisbah adalah lembaga negara yang memiliki wewenang yang sangat luas yang bertugas mempromosikan apa yang baik dan mencegah hal-hal yang buruk (amar ma'ruf nahi munkar). Ibnu Taimiyah menekankan prinsip keadilan sebagai penopang lembaga Hisbah dalam pemerintahan Islam. Keadilan adalah penopang pemerintahan dan itu adalah syarat mutlak agar datangnya pertolongan Allah. 
2. Ibnu Taimiyyah rahimahullah telah menetapkan persyaratan yang ketat bagi calon seorang pemimpin dengan memiliki karakter penting berikut ini :

(1). Al-Muslim (artinya bukan Non Muslim)

(2). Al-Qowiy (kekuatan, keberanian, ketegasan),

(3). Al-Amin (amanah, cerdas, memiliki keahlian dan bertanggung jawab),

(4). Al-Adl (hanif dan lurus dalam menjalankan agamanya dan adil ketika menetapkan hukum),

(5). Al-Khasyyah (sifat seorang ulama yang tidak neko-neko karena dia hanya takut kepada Allah Azza wa Jalla,

Ibnu Taimiyyah rahimahullah menjadikan syarat yang paling mendasar pada diri seorang pemimpin itu adalah dia wajib seorang "muslim yang hanif", khusus tentang persyaratan ini Ibnu Taimiyyah rahimahullah berkata : "Jika kepemimpinan dipisahkan dari agama Islam, atau agama Islam dipisah dari kepemimpinan maka hal itu akan merusak tatanan kehidupan manusia” (al-Siyâsah al-Syar'iyyah, Hal. 176)

Menurut Ibnu Taimiyyah rahimahullah kepemimpinan Non Muslim di tengah kaum muslimin adalah haram dan tertolak, hal ini bisa dipahami berdasarkan ungkapan beliau (النهي عن موالاة الكفار) artinya "larangan menjadikan orang-orang kafir sebagai pemimpin" dan juga tulisan beliau pada karyanya yang lain : ( اليَهُودِ
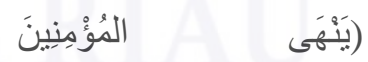
artinya "Allah melarang orang-orang beriman untuk menjadikan orangorang Yahudi dan Nasrani sebagai pemimpin”. Bentuk-bentuk penolakan Ibnu Taimiyyah rahimahullah terhadap kepemimpinan Non Muslim di 
tengah kaum muslimin, maka penulis telah menukilkan argumentasi beliau tersebut dalam 17 poin ungkapannya di bagian akhir bab IV.

Konsep dan idealisme Ibnu Taimiyyah dalam mengatur kehidupan bermasyarakat, bernegara dan berbangsa itu sangat memiliki relevansi dengan kehidupan kekinian, karena konsep yang beliau tawarkan dalam berbagai karya ilmiahnya itu benar-benar tidak mengalami expired, sebab konsep tersebut benar-benar dibutuhkan oleh masyarakat secara umum dan kaum muslimin secara khusus. Penilaian secara objektif maka ide dan konsep Ibnu Taimiyyah tersebut diatas tidak ada sedikitpun bertentangan dengan UUD 1945 dan Pancasila.

\section{B. Saran}

Setelah melakukan penelitian dan analisis terhadap kepala negara Non Muslim menurut Ibnu Taimiyyah, maka penulis memberikan beberapa saran yang bersifat membangun dan konstruktif sebagaimana berikut ini:

Mengingat negara kita Indonesia ini penduduknya adalah mayoritas beragama Islam, maka oleh karena itu diharapkan kepada pemangku kepentingan di negara ini agar memperhatikan aspirasi umat Islam yaitu agar yang dicalonkan sebagai pemimpin pada masyarakat Islam itu hendaklah seorang calon yang memiliki aqidah dan keyakinan yang sama yaitu seorang Muslim, hal ini tujuannya adalah untuk menghindari agar tidak terjadi gesekan dan pertikaian pada masyarakat Indonesia.

Mengingat mekanisme pemilihan pemimpin yang dianut di negara kita melalui pemilihan seacara langsung, sehingga memberikan kesempatan kepada semua pihak termasuk dalam hal ini Non Muslim, untuk bisa 
dicalonkan atau mencalonkan diri untuk menjadi pemimpin, maka oleh karena itu sangat diharapkan kepada kaum muslimin agar berpegang kepada ayat-ayat Iahi yaitu wahyu dari al-Quran maupun al-Sunnah yang secara umum melarang memilih pemimpin Non Muslim khususnya untuk menjadi pemimpin pada masyarakat Islam, karena termasuk salah satu kewajiban seorang muslim yang paling mendasar adalah mendahulukan ayat-ayat Ilahi daripada ayat-ayat konstitusi, sebab hal ini telah dijamin oleh ayat-ayat konstitusi yang berlaku di Indonesia yaitu : Pasal 29 UUD 1945 Tentang Kebebasan Beragama Pasal 29 : Ayat (1) Negara berdasar atas Ketuhanan Yang Maha Esa. Ayat (2) Negara menjamin kemerdekaan tiap-tiap penduduk untuk memeluk agamanya masing-masing dan untuk beribadat menurut agamanya dan kepercayaannya itu.

Negara kita ini masyarakat sangat majmuk maka hendaknya setiap warga negara Indonesia saling menjaga hubungan antar agama dan jangan ada lagi hendaknya seorang warga negara Indonesia menuding warga negara Indonesia lainnya dengan tudingan intoleran, anti NKRI, anti Binneka Tunggal Ika, anti Pancasila dan anti kepada UUD 45, hanya karena dia itu menjadikan agamanya sebagai acuan dalam kehidupan berbangsa dan bernegara, sebab kebebasan menjalankan kehidupan beragama itu sudah dijamin oleh konstitusi kita bangsa Indonesia yaitu Pasal 29 UUD 1945 Tentang Kebebasan Beragama Pasal 29 : Ayat (1) Negara berdasar atas Ketuhanan Yang Maha Esa. Ayat (2) Negara menjamin kemerdekaan tiaptiap penduduk untuk memeluk agamanya masing-masing dan untuk beribadat menurut agamanya dan kepercayaannya itu. 


\section{DAFTAR PUSTAKA}

A $\bar{b} u$ Abdillah Muhammad bin Ismail bin Ibrahim bin al-Mughirah bin Bardizbah al-Ju'fi al-Bukhôri, Shahih Al-Bukhôri, Penerbit Daru Ibnu Katsir, AlYamamah Bairut, cet. III 1407H/1987M

Abu Al-Hasan 'Ali bin Muhammad bin Muhammad bin Habib Al-Bashori AlBaghdady, yang tersohor dengan sebutan (Imam) Al-Mawardi, wafat 450H, Al-Ahkâmu al-Sulthôniyyah

Abu Muhammad Ali bin Ahmad bin Sa'id bin Hazm bin Ghalib bin Sholeh bin Khalaf bin Ma'dan bin Sufyan bin Yazid Al-Farisi (384-Sya'ban 456H), Maratib Al-Ijma' fi al-Ibâdât wa al-Mu'amalât wa al-I'tiqodât, Daru alKutub al-'Ilmiyyah, Bairut 1 Jilid.

Abu Dawud Sulaiman bin Al-Asy'ats Al-Sijistani (817-889M) di dalam kitabnya Sunan Abi Daud, , di tahqiq dan diberi catatan kaki oleh Syekh Al-Bani, Penerbit Dar al-Kitab al-'Araby, Bairut Lebanon, 4 Jilid

Ab Zahrah, Ibnu Taimiyah (Mesir: Dâr al-Fikir al-Arabi, 1991 M)

Ahmad bin Muhammad bin Hambal bin Hilal bin Asad Al Marwazi Al Baghdadi/Ahmad bin Muhammad bin Hanbal dikenal juga sebagai Imam Hambali, (wafat 241H), Musnad al-Imam Ahmad bin Hambal, Peneliti Ahmad Muhammad Syakir, Penerbit Dâru al-Hadits Kairo Mesir, Cet. I, Th. 1416H /1995M, 8 Jilid

Adiwarman Azwar Karim, Sejarah pemikiran Ekonomi Islam, (Jakarta: PT.Raja Grafindo Persada, 2006),

Ahmad Djazuli, Fiqh Siyasah Implementasi Kemaslahatan Umat dalam Ramburambu Syariah, (Jakarta: Kencana Prenada Media Grup, 2003)

Amiruddin dan Zainal Asikin, Pengantar Metode Penelitian Hukum, Jakarta: Rajawali Pers, 2010.

Ahmad Djazuli, Fiqih Siyasah, (Bogor : Kencana, 2003) 
Anslem Strauss dan Juliet Corbin, Dasar-Dasar Penelitian Kualitatif, alih bahasa M. Shodiq dan Imam Muttaqien, Yogyakarta: Pustaka Pelajar, 2009.

Antony Black, Pemikiran Politik Islam Dari Masa Nabi Hingga Masa Kini, 2001, Jakarta: Serambi

Al-Qurthubi, Tafsir al-Qurthubi, penerjemah Fathurrahman dkk, terjemahan dari kitab Al-Jâmi li Ahkâm al-Qur'ân, (Jakarta: Pustaka Azzam, 2010)

Ali Al-Salus, Imamah dan Khalifah, (Jakarta: Gema Insan Press, 1997)

Bukhari, sesuai dengan nomor yang terdapat dalam Kitab Fathu al-Bâri, Penerbit Dar al-Sya'bi Kairo Mesir, Cet. Tahun 1407H/1987M, Jumlah 9 Jilid

Bambang Sunggono, Metodologi Penelitian Hukum, Jakarta: Raja Grafindo Persada, 1998.

Baharuddin \& Umiarso, Kepemimpinan Pendidikan Islam, (Yogyakarta: ar Ruzz Media, 2012)

B. Lewis,et. All, the Encyclopedia of Islam, (Laiden: E.J. Brill, 1979)

Cik Hasan Bisri, Penutun Penyusunan Rencana Penelitian dan Penulisan Skripsi, Bandung: Ulul Albab Press, 1997.

Dede Rodin, Kepemimpinan Non Muslim Dalam Perspektif Al-Qur'an, Mutawâtir Jurnal Keilmuan Tafsir Hadis Volume 7, Nomor 1, Juni 2017. Universitas Islam Negeri (UIN) Walisongo Semarang

Departememen Pendidikan dan Kebudayaan, Kamus Besar Bahasa Indonesia, (Jakarta: Balai Pustaka, 1994), cet. ke-4,

Departemen Agama RI Al-Qur'an dan Terjamahannya, Cet. Majma' al-Malik Fahd Tahun 1435H, Madinah Munawwarah KSA

Didin Hafidhuddin K.H. dan Hendri Tanjung S.Si, MM, Manajemen Syari'ah dalam Praktik, Cet. I, Jakarta; Gema Insani Perss, 2003

Emzir, Analisis Data : Metodologi Penelitian Kualitatif, Jakarta : Rajawali Press, 2011 
Euis Amalia, Sejarah Pemikiran Ekonomi Islam dari Masa Klasik hingga Kotemporer, (Depok: Gramata Publishing, 2010)

Hendiyat Soetopo dan Waty Soemanto, Kepemimpinan dan Supervisi Pendidikan, (Jakarta: Bina Aksara, 1984),

Hasan Konakata, DR. al-Nazhariyyah al-Siyâsah 'Inda Ibni Al-Taimiyyah, Dar Al-Akhilla' Dammam, Markaz a-Dirâsât wa al-A'lâm Dar al-Asyiliyyah Riyad KSA, Cet. I Tahun 1415H/1994M

Ibnu Qoyyim al-Jauziyyah, Muhammad bin Abi Bakar bin Ayyub bin Sa'ad alZar'iy al-Dimasqiy, Abu Abdillah Syamsuddin dan dikenal dengan Ibnu Qoyyim al-Jauziyyah, Ahkâm Ahli al-Zhimmah, diteliti oleh Toha Abdul al-Ra'ûf Sa'ad, Penerbit: Dâru al-'Ilmiyyah, Bairut Lebanon, cetakan kedua, cetakan $1423 \mathrm{H} / 2002 \mathrm{M}$

Ibnu Qayyim al-Jawziyyah, Muhammad Bin Abi Bakar Ayyub al-Zar'iy Abu Abdillah Syamsuddin dikenal dengan Ibnu Qayyim al-Jawziyyah, I'lâm al-Muwaqqi'în 'an Rabbi al-'alamin (Bairut: Dâr al-Jil, th1973), diteliti ulang oleh Toha Abdu al-Rauf Sa'ad, jumlah 4 Jilid

Ismail bin Umar Al-Quraisyi bin Katsir Al-Bashri Ad-Dimasyqi, Imaduddin Abu Al-Fida Al-Hafizh Al-Muhaddits Asy-Syafi'i, (700-774H) Tafsir Ibnu Katsir, diteliti ulang oleh Sâmiy bin Muhammad Salâmah, Penerbit Daru Thaiyibah, Cet. II 1420H/1999M, Jumlah 8 Jilid

Ibnu Hajar al-Asqolany, namanya adalah Syihabuddin Abu al-Fadhl Ahmad bin Ali bin Muhammad bin Muhammad bin Ali bin Mahmud bin Ahmad bin Hajar, Fathu al-Bâri, Diteliti ulang oleh Ahmad bin Ali bin Hajar Abu alFadhl al-Asqolany al-Syafi'i, Daru al-Ma'rifah Bairut Th. 1379H, 13 Jilid

Ibnu Taimiyyah, Taqiyu al-Dîn Abu al-Abâs Ahmad bin Abdul Halim bin Taimiyyah al-Harâny (661-728), Al-Ikhtiyârâtu al-Fiqhiyyah, ditela'ah oleh Ali bin Muhammad bin Abâs al-Ba'la Al-Dimayqi, Penerbit: Dâru alMa'rifah, Bairut Lebanon, cetakan 1397H/1978M 
Al-Siyâsah al-Syar'iyyah, Cetakan I, Penerbit Wizârah al-Syu'ûni alIslamiyyah wa al-Auqâf wa al-Dakwah wa al-Irsyadi, KSA, terbitan tahun 1418H, 1 Jilid, jumlah halaman 136.

Iqtidhô' al-Shirâti al-Mustaqîmi li Mukhôlafati Ashhâbi al-Jahîm, ditela'ah oleh DR. Nashir Abdul Karim Al-‘Aql, Penerbit: Maktabah AlRusydi-Riyadh, Jumlah 2 Jilid

Ibnu Taimiyyah, Taqiyu al-Dîn Abu al-Abâs Ahmad bin Abdul Halim bin Taimiyyah al-Harâny (661-728), Al-Furqôn Baina Auliyâ' al-Rahmân wa Auliyâ' al-Syaithôn, Peneliti \& Pengomentar Ali bin Nâyif al-Syahûd, Pentela'ah pada al-Qur'an dan al-Sunnah

Al-Khilâfah wa al-Mulk, ditela'ah oleh Abdu Al-Rahmân Muhammad Qosim Al-Najdiy, Penerbit: Maktabatu Ibnu Taimiyyah, Jumlah 1 Jilid Al-Siyâsah al-syar'iyyah fi ishlâhi al-râ'i wa al-ra'iyyah, Cetakan Dâru Al-Ma'rifati Jumlah 1 Jilid

Al-Hisbah, (Versi Maktabah Syamilah)

- Majmu' al-Fatawa Peneliti Anwar al-Baz \& 'Amir Al-Jazzar, Penerbit Dâru al-Wafa', Cet. III Tahu 1426H/200M, Jumlah 37 Jilid

-_e---- Kutub Wa Rasâ'il Wa Fatâwâ Ibnu Taimiyyah Fi al-Fiqh, diteliti ulang oleh Abdu al-Rahman bin Muhammad bin Qasim al-'Ashimi al-Najdi, Maktabah Ibnu Taimiyyah (Versi Maktabah Syamilah)

Pedoman Islam Bernegara, terjemahan Firdaus AN, (Jakarta : Bulan Bintang, 1960)

Al-Furqan Baina Auliyâ' al-Rahman, Alih bahasa oleh Abdul Aziz, Mr. (Yogyakarta: Mitra Pustaka, 2005),

- Tugas Negara Menurut Islam, 2004, Yogyakarta: Pustaka Pelajar Al-Siyasah al-Syar'iyah Etika Politik Islam, Terjemahan oleh Rofi' Munawwar, dari kitab Al-Siyâsah al-Syar'iyyah fì Islâhi al-Râ'iy wa alRâ'iyyah, (Surabaya: Risalah Gusti, 2005) 
Jon Kamil, Tesis Perkawinan Antar Pemeluk Agama Perspektif Fiqh Ibnu Taimiyyah, (UIN Suska Riau : pasca sarjana, 2011).

J. Suyuti Pulungan, Fiqih Siyasah; Ajaran dan Pemikiran, Jakarta; PT.Raja Grafindo Persada, Cet III, 1997, Ed. I

Kartini Kartono, Pemimpin dan Kepemimpinan, (Jakarta: Raja Grafindo Persada, 2009)

Khalid Ibrahim Jindan, Teori Politik Islam : Telaah Kritis Ibnu Taimiyyah tentang Pemerintahan Islam, Alih bahasa Masrinin, (Jakarta : Risalah Gusti,1995)

Louis bin Nakula Dhahir Ma'luf, Al-Munjid fi al-Lughah wa al-A'lam, (Beirut: Dâr al-Machreq sarl Publishers, 2000)

Mahmud Yunus, Kamus Arab-Indonesia Mahmud Yunus, (Jakarta: Mahmud Yunus Wa Dzurriyyah, 1999)

Muhammad Sholeh Al-Utsaimin, 'Ilmu Musthalahi Al-Hadits, (Versi Maktabah Syamilah)

Muhammad Rasyîd Ridho, Al-Khilâfah, Penerbit; Al-Zahrô' Li- 'Alâmi al- 'Arabi, Kairo Mesir, Jumlah 1 Jilid (Versi Maktabah Syamilah)

Munawir Sjadzali, Islam dan Tata Negara : Ajaran, Sejarah dan Pemikiran (Jakarta : UI Press, 1990)

Muhammad Iqbal, 100 Tokoh Terhebat dalam sejarah Islam, (Jakarta : Inti Media, 2003)

Muhammad Amin, Ijtihad Ibnu Taimiyyah Dalam Bidang Figh Islam, (Jakarta: INIS,1991)

Muhammad Ryass Rasyid, Makna Pemerintahan; Tinjauan dari Segi Etika dan Kepemimpinan, PT. Mutiara Sumber Wijaya. 2000 Cet. I,

Muslim, Abul Husain Muslim bin al-Hajjaj al-Qusyairi al-Naisaburi (821-875), Kitab Shahih Muslim, Pentela'ah Muhammad Fu'ad Abdu al-Baqi, Penerbit Daru Ihya' al-Turats al-Araby, Bairut, Jumlah 5 Jilid 
Mujar Ibnu Syarif, Khamami Zada, Fiqh Siyasah Doktrin dan Pemikiran Politik Islam, (Jakarta: Erlangga, 2008)M. Dhiauddin Rais, Teori Politik Islam, (Jakarta: Gema Insani Press, 2001)

Nâwawi, al-Allamah Abu Zakaria Muhyuddin bin Syaraf an-Nawawi adDimasyqi, (676H) Al-Minhaj Syarhu Shahih Muslim bin al-Hajjâj, Masdar Kitab: Mauqi’ al-Islam

Neni, Pemikiran Ibnu Taimiyyah Tentang Talqi Al-Wafidain, (Pekanbaru: UIN Suska Riau, 2011)

Qamaruddin Khan, The political Thought of Ibnu Taimiyah, terj. Anas Mahyuddin, (Bandung Pustaka,1983),

Saifuddin Azwar, Metode Penelitian, Yogyakarta: Pustaka Pelajar, 2007

Soerjono Soekanto, Pengantar Penelitian Hukum, Jakarta: UI-Press, $1986 .$.

Sudarwan Danim dan Suparno, Manajemen dan Kepemimpinan Transformasional Kekepalasekolahan: Visi dan Strategi Sukses Era Teknologi, Situasi Kritis, dan Internalisasi Pendidikan, (Jakarta : Rineka Cipta, 2009),

Syaikh Said Abdul Azhim, Ibnu Taimiyah Pembaharuan Salafi dan Dakwah Reformasi, Terj, Faisal Saleh, (Jakarta: Pusstaka AL-Kautsar, 2005)

Syaikh Ahmad Farid, 60 Biografi Ulama Salaf, Terj. Masturi Irham dan Assmu'i Taman, (Jakarta: Pusstaka Al-Kautsar, 2006), Cet.ke-1

Sholeh Fauzan, Dr. Sholeh bin Fauzan bin Abdullah Al-Fauzan. Kitab Tauhid Jilid I, diterjemahkan oleh KH. Dr. Agus Hasan Bashori, Lc. MA. Penerbit Darul Haq Jakarta, Cet. XXIV Tahun 2015

Taufiqi Rahman, Moralitas Pemimpin dalam Perspektif al-Quran, (Bandung: CV Pustaka Setia, 1999),

Universitas Islam Mandinah Internasional, al-Siyâsah al-Syar'iyyah, Rumus code GFIQ5203, Kitab/buku pegangan pada program pascasarjana Universitas Islam Mandinah Internasional, penyusun adalah team kurikulum, penerbit Universitas Islam Mandinah Internasional, jumlah 1 jilid 
Uhar Suharsaputra, Metode Penelitian Kualitatif, Kuantitatif dan Tindakan, Bandung : Rafika Aditama, 2012.

Wahjosumidjo, Kepemimpinan dan Motivasi, Jakarta; Ghalia Indonesia, 1987. Cet. III

Yunasril Ali. Kepemimpinan dalam Perspektif Islam, (Bandung: Angkasa, 2008) Yayasan Obor Indonesia, Metode Penelitian Kepustakaan, Jakarta : Yayasan Obor Indonesia, 2004 


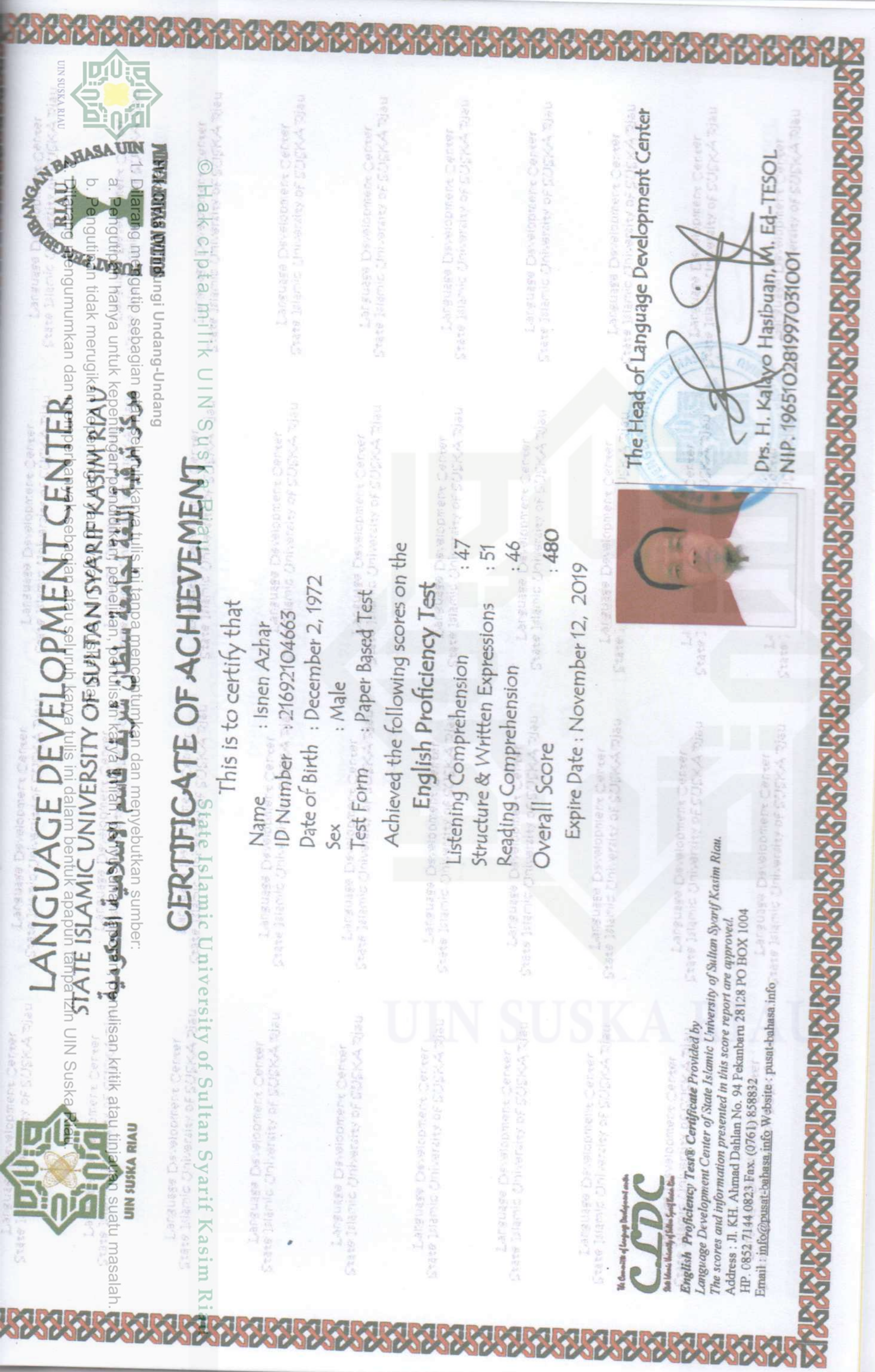


미를

asion

खरำ

oneren

o 0

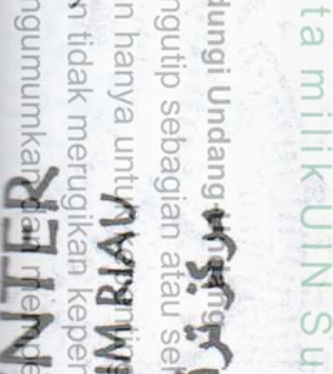

(घ) 5 की क

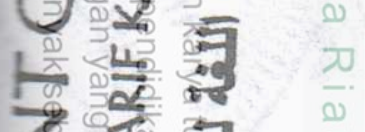

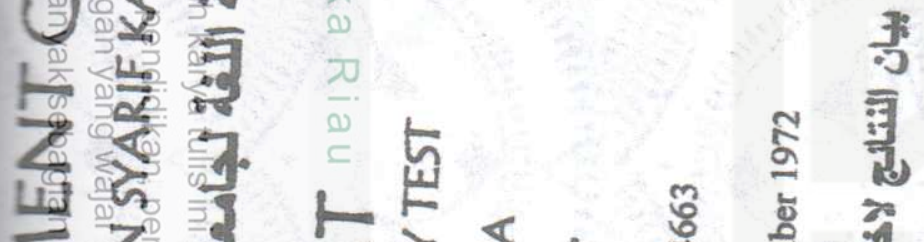

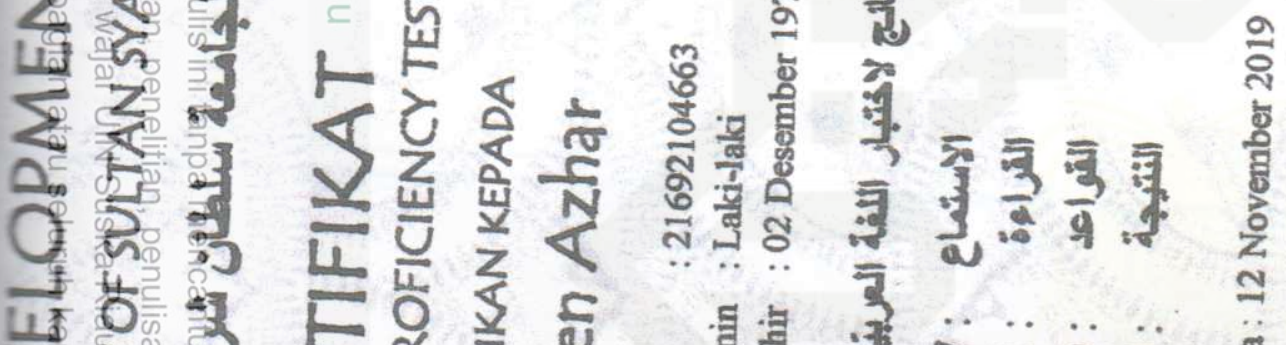

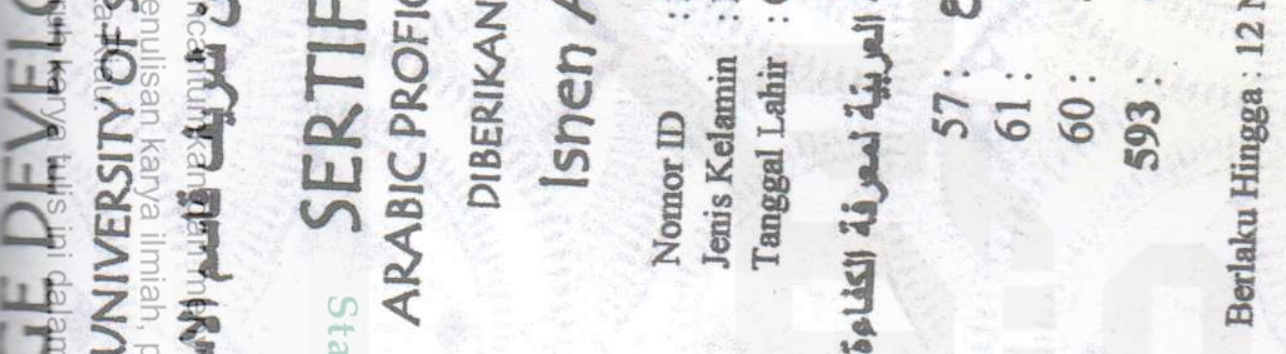

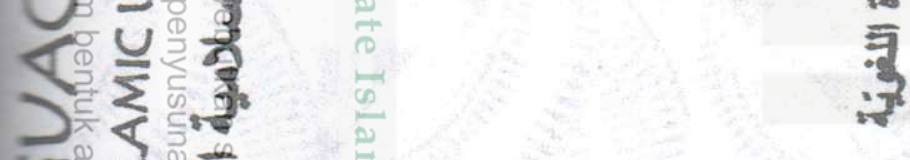

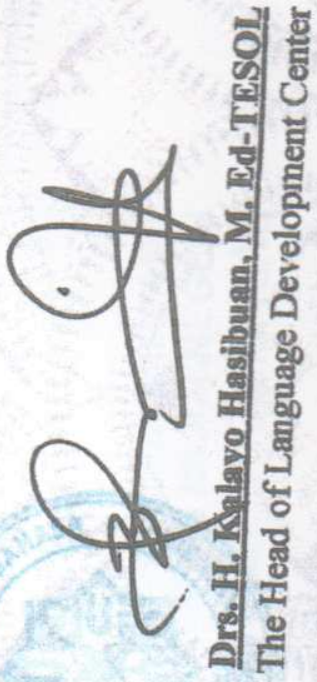

$\checkmark \frac{5}{\omega}$

$\left\{\frac{5}{3} \frac{5}{2}\right.$

$-\bar{N}$

$\underline{\underline{Z}}$

告) 


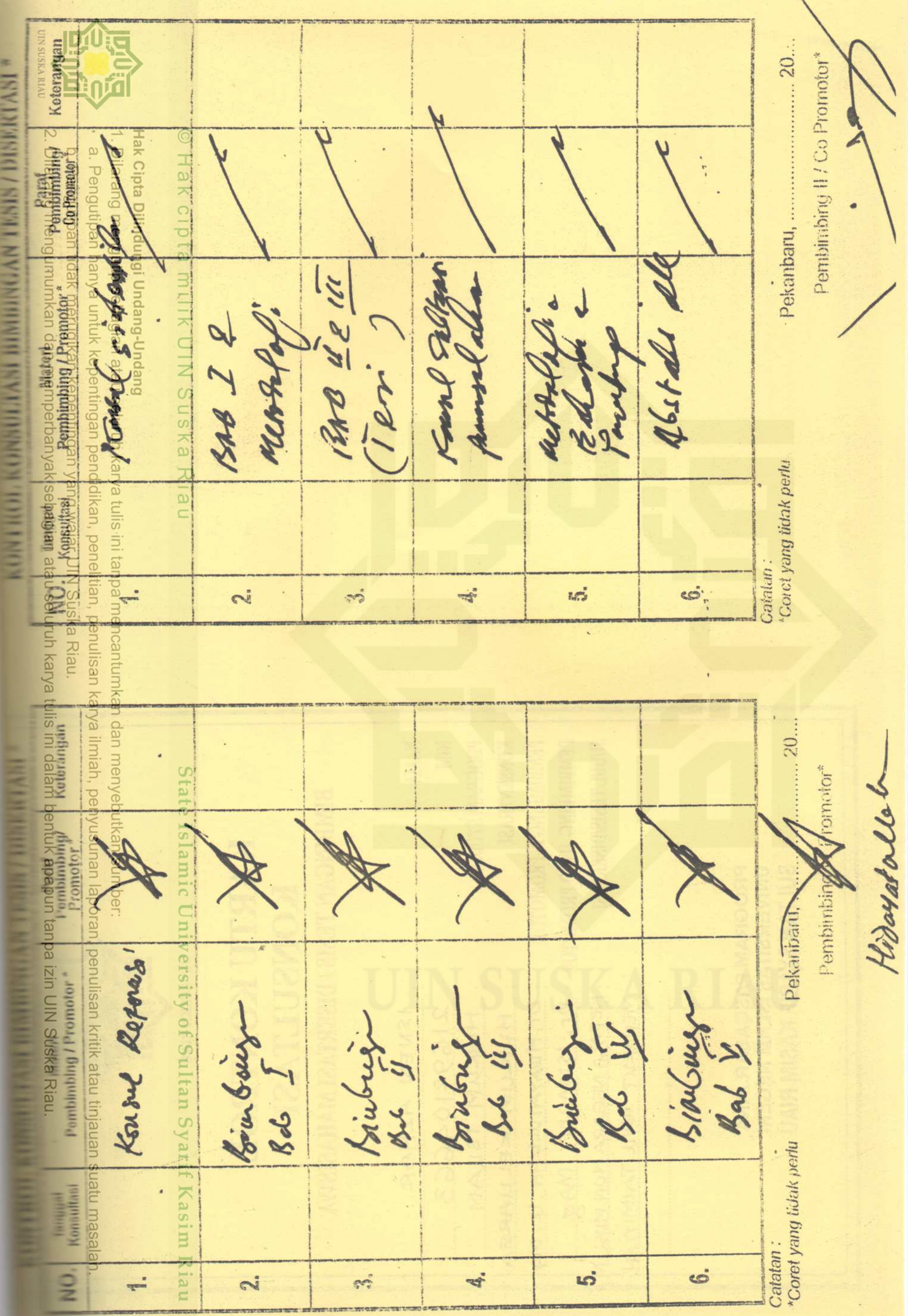




\section{BIODATA PENULIS}

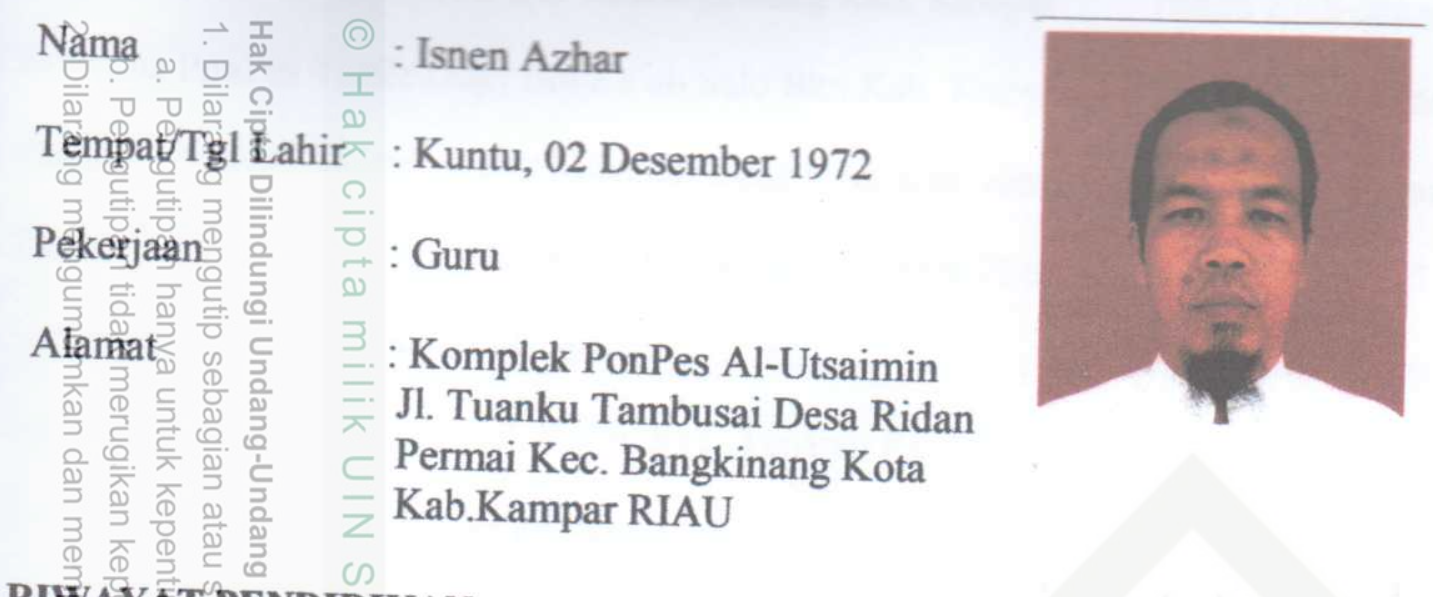

\section{RIWAY TTPNDIDIKAN}

告

S2 Hur Hukum Keluarga UIN SUSKA Pekanbaru RIAU

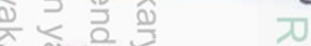

: Lulus 2019

S2 Jur.Figh Medina International University MEDIU Malaysia $\quad$ : Semester 3, 2012

S1 Porusan Syari'ah pada Universitas Ibnu Sa'ud (LIPIA Jakarta) : Lulus 2001

Dipforma B Ârab (I'dad Lughawi 2 Tahun) LIPIA Jakarta क क गे

: Lulus 1997

MAP Pes Daarun Nahdhah Thawalib Bangkinang RIAU : : Lulus 1993 MTs Swasta Kuntu Kec. Kampar Kiri Kab. Kampar RIAU : : Lulus 1988

SDN012 Kuntu Kec. Kampar Kiri Kab. Kampar RIAU : Lulus 1985

\section{RIWAYAF PEKERJAAN}

Pegawai Pada Bagian Perpustakaan LIPIA Jakarta

Pegaxyai Yayasan Al-Sofwa Jakarta

Waka Kurikumum Padâ P
Ubudiyyah Pekanbaru RIAU
궁
:

Ubudìyyah \$ekanbaru RIAU

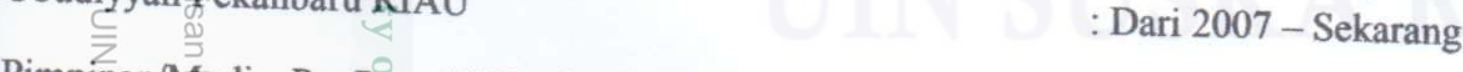

Pimpinan/Mudir PonPes Al-Utsaimin Bangkinang RIAU dibawah Yayasan Lajnah AlKhairiyyah Al-Musytarakah Jakarta Cab. Bangkinang RIAU : Dari 2016-Sekarang Mengisi Kajian Ilmiah dan Pemateri Dauroh (Pelatihan) di berbagai Masjid, Universitas, Kampus, Organisasi, dan beberapa tempat : Dari 1998 - Sekarang 